\title{
İki Dünya Savaşı Arasında Türkiye'de Zehirli Gazlardan Korunma Kursları ve Yasal Düzenlemeler
}

\section{Training Courses for the Protection from Poisonous Gases and Legal Regulations between the Two World Wars in Turkey}

\author{
Eyüp Talha Kocacık ${ }^{1}$ (]) Emre Dölen ${ }^{2}$ (1)
}

'Eczacı, Kocacık Eczanesi, Sağlık Cad. No. 3/L Adapazarı, Sakarya, Türkiye

2Prof. Dr., Marmara Üniversitesi,

Eczacılık Fakültesi, Emekli Öğretim Üyesi, Istanbul, Türkiye

ORCID: E.T.K. 0000-0002-6667-1339;

E.D. 0000-0002-3670-3627

Sorumlu yazar/Corresponding author: Eyüp Talha Kocacık,

Kocacık Eczanesi, Sağlık Cad. No: 3/L Adapazarı, Sakarya, Türkiye

E-posta/E-mail: eyuptalha@kocacik.com

Başvuru/Submitted: 05.09 .2019 Revizyon Talebi/Revision Requested: 18.10.2019

Son Revizyon/Last Revision Received:

28.10.2019

Kabul/Accepted: 04.11 .2019

Online Yayın/Published Online: 03.01.2020

\section{Atıf/Citation:}

Kocacık, Eyüp Talha ve Emre Dölen. “iki Dünya Savaşı Arasında Türkiye'de Zehirli Gazlardan Korunma Kursları ve Yasal Düzenlemeler." Osmanlı Bilimi Araştırmaları 21, 1 (2020): 1-56. https://doi.org/10.26650/oba.669431

\section{öz}

Kimyadaki gelişmeler, Birinci Dünya Savaşı'nda zehirli gazların kullanılmasına olanak sağlamış, ancak 1925 yılında Cenevre'de imzalanan protokol bile bunların kullanımını durduramamıştır. Bunun üzerine çeşitli ülkelerde gerek halkı bilinçlendirmek gerekse de olası bir savaş durumunda korunmayı sağlamak için kurslar, eğitimler düzenlenmeye başlanmıştır. Genç Türkiye Cumhuriyeti de bu ülkelerden biridir. Cumhuriyet yönetimi, yaklaşmakta olan İkinci Dünya Savaşı́na giden yolu dikkatle izlemiş ve kendi içinde gerekli önlemleri almıştır. Öncelikli olarak, konferanslar düzelenmiş, orta ve lise okullarının müfredatlarına zehirli gazlardan korunmaya yönelik dersler konulmuştur. Bu çerçevede, doktor, eczacı, öğretmen, kimyager gibi belirli meslek mensuplarının zehirli gazlar hakkında özel kurslarda eğitilerek bunların yöneticilere, memurlara, itfaiyecilere ve genel halk için açılan kurslarda ders vermeleri sağlanmıştır.

Bu makalede, Avrupa'da zehirli gazın kullanımı hakkında bilgi verildikten sonra, birinci ve ikinci dünya savașları arasındaki dönemde Türkiye'de zehirli gazlar üzerine düzenlenen yasa ve talimatnameler ele alınacaktır. Ardından zehirli gazlar konusunda yapılan sosyal düzenlemeler ve zehirli gazdan korunma kursları incelenecektir.

Anahtar sözcükler: Zehirli gazlar, İkinci Dünya Savaşı, hava saldırısı, gaz taarruzu, kimya harbi

\section{ABSTRACT}

Developments in chemistry paved the way for the use of poisonous gases during World War I. Despite a protocol having been signed in Geneva in 1925 , the development and use of poisonous gases could not be prevented. Numerous countries began to hold courses to train civilians in order to raise awareness and teach self-protection. The Turkish Republic was among them. While institutions held conferences, special courses were added to the secondary and high school curricula. Members of various professions such as doctors, pharmacists, teachers and chemists who were trained in such courses taught about poisonous gases to administrators, civil servants, and firemen, as well as to the general population. 
After a short introducton on the use of poisonous gases in Europe, this present article will first study the laws and bylaws issued in Turkey. Then it will focus on courses held to protect Turkish civilians from possible toxic gas attacks throughout the period between WW1 and WW2.

Keywords: Poisonous gases, Word War II, air strikes, poisonous gas attacks, chemical warfare

\section{Giriş}

Bilim, sanayi ve teknolojideki ilerlemelerin sonuçları her zaman için insanlık yararına kullanılmamıştır. Modern kimya biliminin ortaya çıkmasının ardından Sanayi Devrimi’nin getirdiği teknolojik gelişmelerin kimyasal maddelere olan talebi artırması ve sentetik boyarmadde ihtiyacı kimya biliminin ilerlemesine hız kazandırmıştır.

Kimyanın bilim olarak ortaya çıkışından yüzyıllar önce, kimyasal bilgi ve güç, iktidar hırsının bir aracı olarak kullanılmaya çalışılmıştır. Örneğin M. Ö. 431-404 yıllarında İranlılar ile Yunanlılar arasında yapılan Peloponnez savaşlarında kükürt, zift, odun ve kömürün yanması sonucu ortaya çıkan dumanla düşman bertaraf edilmeye çalışılmıştır. ${ }^{1}$ Bizans askerleri, İstanbul'u almaya çalışan Arap ve Türk akıncılarına karşı kükürt, zift, potasyum nitrat, balık nefsi², tuz, gaz yağı ve zeytinyağından oluşan ve Rum Ateşi ${ }^{3}$ olarak adlandırılan malzemeyi kullanılmıştır. ${ }^{4}$

İlk defa Johann Baptista van Helmont (1580-1644) tarafindan, damitma sirasinda yoğunlaşmayıp uçup giden maddeler "ehlileştirilemeyen vahşi ruhlar” olarak tanımlamış ve kaos sözcüğünden "gaz” terimi türetilmiştir. Bataklıklardan çıkan yanıcı hava (metan gazı), madenlerde patlamalara neden olan grizu (metan gazı), mağaralarda biriken öldürücü gazlar (karbon dioksit) gibi gazlar kimya biliminin ilerlemesiyle birlikte bilim insanlarının dikkatini çekmeye başlamıştır. ${ }^{5}$

Orta Çăğ'dan sonra çeşitli zehirli maddeler savaşlarda silah olarak kullanılmış ve zaman zaman bunların savaşlarda kullanılmasını̈̈nleme konusunda uluslararası girişimler yapılmıştır. Örneğin 1874 Brüksel Sözleşmesi ve 1899 Lahey Barış Konferansı gibi. Ancak kimyasal maddelerin savaşta kullanılması konusunda en dikkat çekici olay, Birinci Dünya Savaşı'nda 22 Nisan 1915'te Almanlar' tarafından Belçika'nın Ypres kenti yakınlarında Fransızlara karşı zehirli gaz olarak klorun kullanılmasıdır. ${ }^{7}$ Almanların bu etkili silahı dünyanın birçok yerinde

1 Nuri Refet Korur, “Gazların Tarihçesi,” Kimyager 3, 9 (1935): 153.

2 Balinaların başından çıkarılan bir yağ çeşididir. Günümüzde kozmetik ve mum yapımında kullanılmaktadır. Bkz. Türkçe Sözlük, 10. bs. (Ankara: Türk Dil Kurumu, 2005), 192.

3 Rum Ateşi; çok zor söndürülen ve etkileyici bir duman yayan petrol kökenli yanıcı bir madde karışımıdır.

4 Sadettin Tektaş, Gaz Harbinde Veteriner Hizmetleri: Orduda ve Memlekette (Ankara: Yüksek Ziraat Enstitüsü 1940), 12.

5 Gazlar konusunda yapılan çalışma ve ilerlemeler için bkz. Emre Dölen, Kimya Tarihinden Kesitler (İstanbul: Türkiye Kimya Derneği, 2018), 176-189.

6 Ali Korur, Gönüllü Hastabakıcılık Kursu Ders Notları Zehirli Gazlar ve İlk Yardımlar (Ankara: Başbakanlık Devlet Matbaas1, 1945), 7.

7 Mazlum [Boysan], “Zehirli Gazlar ve Biz,” Askeri Sihhiye Mecmuası 62, 2 (1933): 152. 
duyulmuş ve uzunca bir süre devam edecek olan korkutucu rüyayı başlatmıştır. Almanların boya, ilaç ve parfümeri sanayiinde ileri olmaları kimya araştırmalarındaki başarılarından ileri gelmektedir. Uzun yıllar kimya alanında yaptıkları çalışmalar neticesinde kimyasal bir savaş silahını da üretmiş olmaları tüm dünyayı ürkütmüştür. Birinci Dünya Savaşı'nda fosgen, difosgen, hardal gazı (iperit) ve klor gibi zehirli gazlar 100.000 kişinin ölmesine ve 900.000 kişide de çeşitli sekellerin kalmasına yol açmıştır. ${ }^{8}$

Birinci Dünya Savaşı sırasında büyük bir etki yaratan zehirli gaz kullanımı, savaş devam ederken de cephede bazı acil önlemlerin alınmasını beraberinde getirmiştir. Wood/wooden gas alarm rattle (Ahşaptan yapılmış [zehirli] gaz alarm çıngırağı) isimli bir alet cephede zehirli gaz kullanımını haber vermede kullanılabilecek en iyi yöntem olarak kabul edilmiştir. ${ }^{9}$

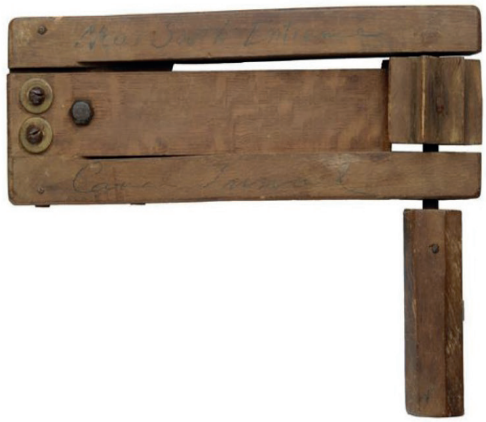

Şekil 1.1. Wood/wooden gas alarm rattle (Ahşaptan yapılmış [zehirli] gaz alarm çıngırağı), (Dăg, "Bir Şehir Efsanesi Olarak," 65).

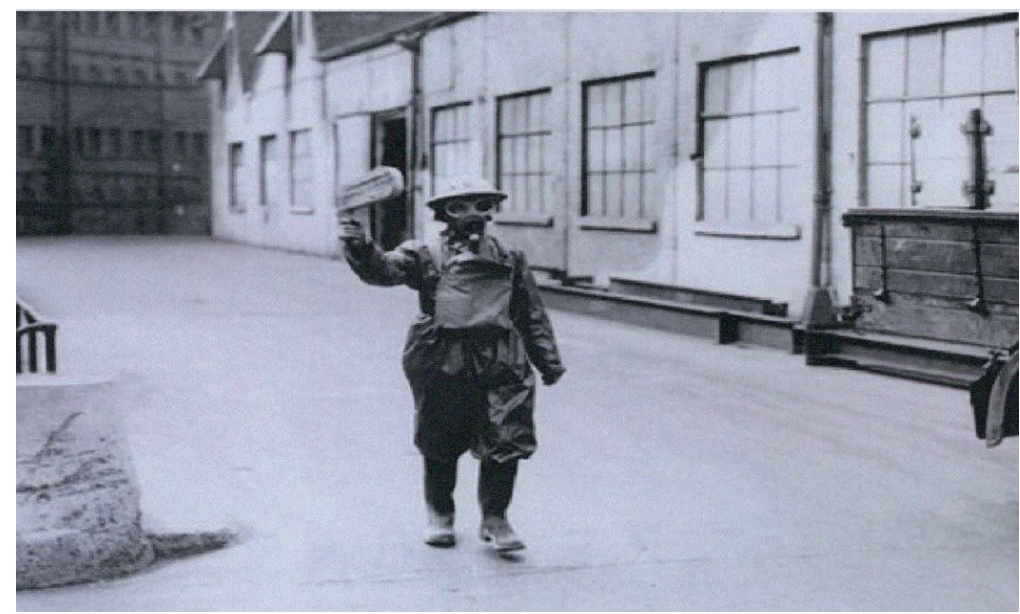

Şekil 1.2. Gaz alarm çıngırağı tutan asker (Dağ, "Bir Şehir Efsanesi Olarak," 66).

8 Pınar Erkekoğlu ve Belma Koçer-Gümüşel, "Kimyasal Savaş Ajanları: Tarihçeleri, Toksisiteleri, Saptanmaları ve Hazırlıklı Olma," Hacettepe University Journal of the Faculty of Pharmacy 38, 1 (January 2018): 25.

9 Murat Dağ, "Bir Şehir Efsanesi Olarak “Tak-Takı"nın Gizemi ve Fransızların Zehirli Gaz Kullandığının İşareti," Gaziantep Üniversitesi Ayıntâb Araştırmaları Dergisi 1, 1 (2018): 63. 


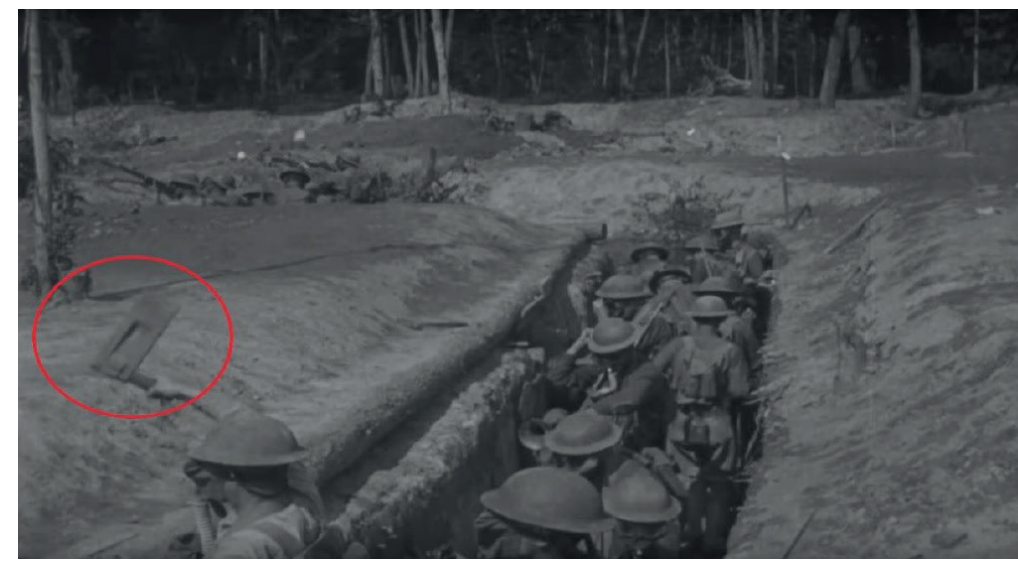

Şekil 1.3. Birinci Dünya Savaşı'nda Amerikalı askerler gaz çıngırağının uyarısıyla gaz maskelerini takıyor, 1918 (Dağ, "Bir Şehir Efsanesi Olarak,” 65).

Zehirli gazların bir savaş silahı olarak kullanılmasını sağlayan teknolojiyle askeri hava gücünün kullanılmaya başlanması paralellik göstermektedir. Zira zehirli gazların karadan atılmasının birtakım problemleri bulunmaktaydı. Karadan atılan zehirli gazların rüzgârın yön değiştirmesiyle gazı atan askerlere dönerek onları zehirlemesi gibi bir durum söz konusudur. Bu nedenle zehirli gazların hava kuvvetleri tarafından kullanılması daha uygun görülmüştür.

Dünya havacılık tarihinde uçaklar ilk kez 1911 yılında Trablusgarp'ta İtalyanlar tarafından Türklere karşı kullanılmıştır. İtalyanlar el bombalarını uçaktan Türk askerlerinin üzerine atarak uçağı bir savaş aracı haline getirmişlerdir. Daha sonra Çanakkale'de de Türklere karşı ciddi hava saldırıları yapılmıştır. ${ }^{10}$ Çanakkale'de İngilizlerin zehirli gaz kullandığı belgelere yansımışsa da çok etkili olmamıştır. ${ }^{11} 1911$ yılında uçakların savaş sahasına girmesiyle başlayıp, 1915 yılında Almanların zehirli gazları düşman askerine karşı kullanmasıyla devam eden yeni bir savaş yöntemi askeri literatüre girmiştir.

Birinci Dünya Savaşı'nda denenen zehirli gaz saldırıları ileriye dönük korkuları da tetiklemiştir. Zira uçaklarla zehirli gazların birleştirilmesiyle oluşturulan silahın sadece cephede kullanılması değil, cephe gerisinde sivil halka yönelik olarak da kullanılabilecek olması endişe uyandırmıştır. Türkiye Cumhuriyeti, kuruluşunun akabinde, bu konuyla ilgilenmiş ve bir takım önlemler almaya çalışmıştır. Henüz İkinci Dünya Savaşı’na yönelik öngörüler ortada yokken, genç Cumhuriyet zehirli gaz konusunu daima önemli gündem maddesi olarak masada tutmuştur.

10 Zafer Toprak, "Türkiye’de Barış Ortamında Savaş Travması: Hava Taarruzuna Karşı Pasif Korunma,” Toplumsal Tarih 163 (2007): 40-41.

11 Sena Coşğun Kandal, "Zehirli Gaz Saldırılarına Karşı Halkın Bilinçlendirilmesi ve Eğitimdeki Yansıması: Gazdan Korunma Dersi (1931-1940),” Turkish History Education Journal 5, 2 (2016): 550. 
Zehirli gazların savaş cephelerinde kullanılması uluslararası bir tehdit gibi görülmüş ve 17 Haziran 1925 tarihinde Cenevre'de, Milletler Cemiyeti'nin himayesinde düzenlenen uluslararası bir konferansta, Muhnik, Müsemmim veya Buna Mümasil Gazların ve Bakteriyolojik Vesaitin Harpte Ístimalinin Men'i [Boğucu, Zehirli veya Diğer Gazların ve Bakteriyolojik Savaş Yöntemlerinin Savaşta Kullanımının Yasaklanması]'na dair bir protokol imzalanmıştır. Türkiye bu konferansa katılmış ve protokolü 17 Haziran 1925 tarihinde imzalamıştır. Protokol 20 Ocak 1929 'da Resmi Gazete'de yayımlanarak kanunlaşmıştır. ${ }^{12}$ Bu protokol imzalanmış olmasına rağmen ülkeler zehirli gazları geliştirmeye devam etmişlerdir. 1929 yılında Salib-i Ahmer [Kızılhaç], ulusal cemiyetleri Lehistan'da [Polonya'da] toplantıya çağırmıştır. Toplantıda zehirli gazlardan korunma yöntemlerini belirlemek ve geliştirmek üzerine durulmuştur. ${ }^{13}$ Birinci Dünya Savaşı'ndan yenik çıkan Almanya yeniden güçlenebilmek için birçok alanda büyük yatırımlar yapmaya başlamıştır. Kimyasal silahların sentezlemesi ve üretilmesi için yeni çalışmaları desteklemiş ve 1930'lu yılarda I. G. Farbenindustrie'yle ${ }^{14}$ kimyasal silahlar üretmek üzere anlaşma yapmıştır. Bu işbirliği içerisinde 1936'da ilk defa üretilen kimyasal silah olan "tabun", 15 Auschwitz'deki toplama kamplarında kullanılmıştır. 1938'de ise, "sarin"”16 ismi verilen yeni bir kimyasal silah üretilmiştir. ${ }^{17}$

Birinci Dünya Savaşı’nda edinilen trajik tecrübeler neticesinde genç Türkiye Cumhuriyeti savaş bitiminden hemen sonra bir takım önlemler almaya başlamıştır. Cephelerde yapılan gaz saldırılarının etkilerini azaltmak veya etkisiz hale getirmek ve bununla birlikte hava saldırıları ve gaz taarruzları konusunda genel bir bilgi düzeyi oluşturmak adına kanun ve talimatnameler yayınlanmıştır. Sivil halkı bilinçlendirmek için günlük gazetelerde haberler yapılmış ve tedbirler sıralanmıştır. Resmi ve özel kurumlar üzerinden hareketle gazdan korunma kursları açılmış ve ülkede bulunan her vatandaşın eğitilmesi amaçlanmıştır. Ortaokul ve lise müfredatlarına zehirli gazdan korunma dersleri eklenmiştir. Neredeyse tüm yurtta genel bir seferberlik havasıyla zehirli gaz saldırıları konusu daima ülke gündeminde tutulmuştur. Zafer Toprak’ın bu konuyla ilgili olan makalesinin başlığı “Türkiye'de Barış Ortamında Savaş Travması: Hava Taarruzuna Karşı Pasif Korunma" ${ }^{18}$ dönemin psikolojisini çok iyi yansıtır.

12 T.C. Resmi Gazete, sayı 1097, 20 Kânunusâni [Ocak] 1929.

13 Coşğun-Kandal, "Zehirli Gaz," 551.

141925 yılında Almanya'da kimyasal madde üretimini ve ilaç endüstrisini tekelleştirmek amaciyla oluşturulan şirketler topluluğudur. Tam adı Interessen-Gemeinschaft Farbenindustrie AG'dir. Kuruluşla ilgili detaylı bilgi için bkz. F. Munoz Lopez, P. Garcia Garcia, ve C. Alamo, "The Pharmaceutical Industry and the German National Socialist Regime: I.G. Farben and Pharmacological Research," Journal of Clinical Pharmacy and Therapeutics 34,1 (2009): 67-77.

15 Canlının merkezi sinir sistemini bloke eden bir sinir ajanıdır. Çok zehirli bir maddedir.

16 Canlının sinir sitemlerinin dengesini bozarak felç meydana getiren zehirli bir gazdır.

17 Erkekoğlu ve Koçer-Gümüşel, "Kimyasal Savaş Ajanları," 25, 28.

18 Toprak, "Türkiye’de Barış," 40-47. 


\section{Türkiye’de Zehirli Gazlar Üzerine Erken Dönem Çalışmaları}

Türkiye Cumhuriyeti, 19201 yılların başından itibaren zehirli gazlar üzerine bir takım askeri ve sivil önlemler almaya başlamıştır. Büyük Erkânı Harbiye Reisliği [Genelkurmay Başkanlığı] zehirli gazlar ve gaz muharebesi üzerine bir dizi talimatname ve kitap yayımlar:

Miralay Sedad, Gaz Muharebesi (Dersaadet: Matbaa-y1 Askeriye, 1921).

Muharabe Gazlarından Korunma Talîmâtnâmesi (İstanbul: Askerî Matbaa, 1927).

Muharabe Gazlarından Korunma Malzemesinin Hazer Vaktinde Muhâfaza ve Bakımına Dâir Talîmât: Müsvedde Halinde (İstanbul: Askerî Matbaa, 1927).

Cephe Gerisinin Havaya Karşı Müdâfaa ve Muhâfazası Talîmâtnamesi (İstanbul: Askerî Matbaa, 1928).

Halk İ̧̧in Havaya Karşı Korunma Talîmâtı D.86 (Ankara: Büyük Erkân-1 Harbiye Reîsliği Matbaas1, 1931).

Gazdan Korunma Talîmâtnâmesi (İstanbul: Askerî Matbaa, 1932)

Büyük Erkânı Harbiye Reisliği'nin dışında yapılan şu yayın ise dikkat çekicidir: Hasan Kadri [Dirim]. Semli Gaz Muhaberesi ve Hastalıklarl (İstanbul: Kader Matbaas1, 1926). Bu kitapta zehirli gaz muharebesinin nasıl yapılacağı, zehirli gazdan ne şekilde korunacağ 1 ve ortaya çıkacak hastalıklarda ne gibi tedbirlerin alınacağı açıklanmaktadır. Kitap aslında doğrudan halka yönelik olmayıp bu işin uzmanı olanlar ve öğretmenler için hazırlanmıştır.

Erken dönem çalışmaları için verilebilecek bir başka örnek ise Darülfünun'da kurulması öngörülen 'Zehirli Gazlar Enstitüsü’dür. Millî Müdafaa Vekâleti 28 Ocak 1929 tarihinde bir yazı ile Başvekâlet'e başvurarak zehirli gazların incelenmesi konusuna verilen önemi ve memleketin savunması açısından bunların incelenmesinin gereği göz önüne alınarak ilerde ne gibi önlemler alınacağını sormuştur. Darülfünun Emaneti'ne iletilen yazıda "gerek kimya tedrisatını takip eden gençlerin taharriyat [araştırma] ve tedkikatta [incelemede] ve gerek Tıp Fakültesi talebe ve mezunlarının tatbikatta bulunabilmeleri için bir enstitünün teşkili için esaslı ve teferruatlı bir programın acilen ihzar [hazırlanması] ve Vekâlete teklif edilmesi” Darülfünun'dan önemle istenmiştir. ${ }^{19}$ Böyle bir enstitünün kurulduğu tam olarak doğrulanamamıştır. ${ }^{20}$

19 Başbakanlık Cumhuriyet Arşivi (BCA), Başbakanlık Muamelat Genel Müdürlüğü (B. MGM) 30.10/45.292.19, 13 Şubat 1929.

20 Emre Dölen, Türkiye Üniversite Tarihi 2: Cumhuriyet Döneminde Istanbul Darülfünunu (1922-1933) (İstanbul: İstanbul Bilgi Üniversitesi, 2010), 249-250. 


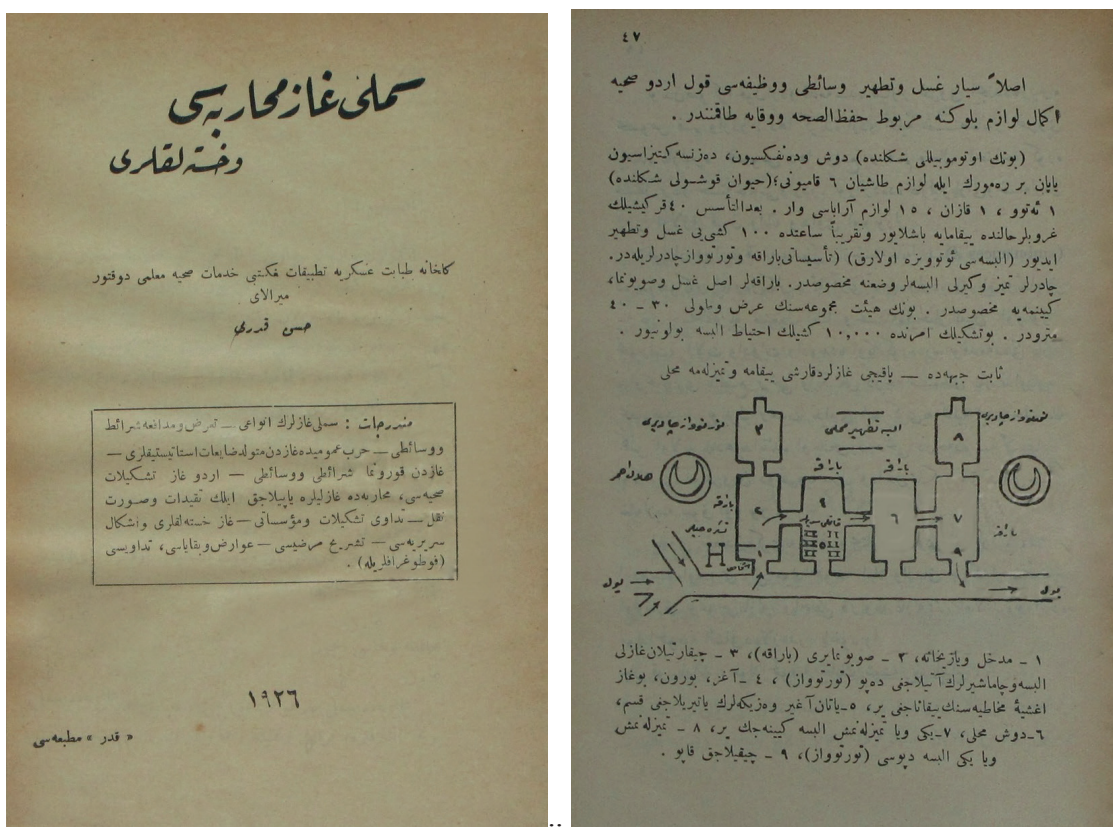

Şekil 2.1. ve 2.2. Hasan Kadri [Dirim], Semli Gaz Muharebesi ve Hastalıkları (1926) kitabının kapağ1 ve s. 47 (İstanbul Büyükşehir Belediyesi Atatürk Kitaplığ̣ K.01780/ 358.34 has 1926 k.1/1).

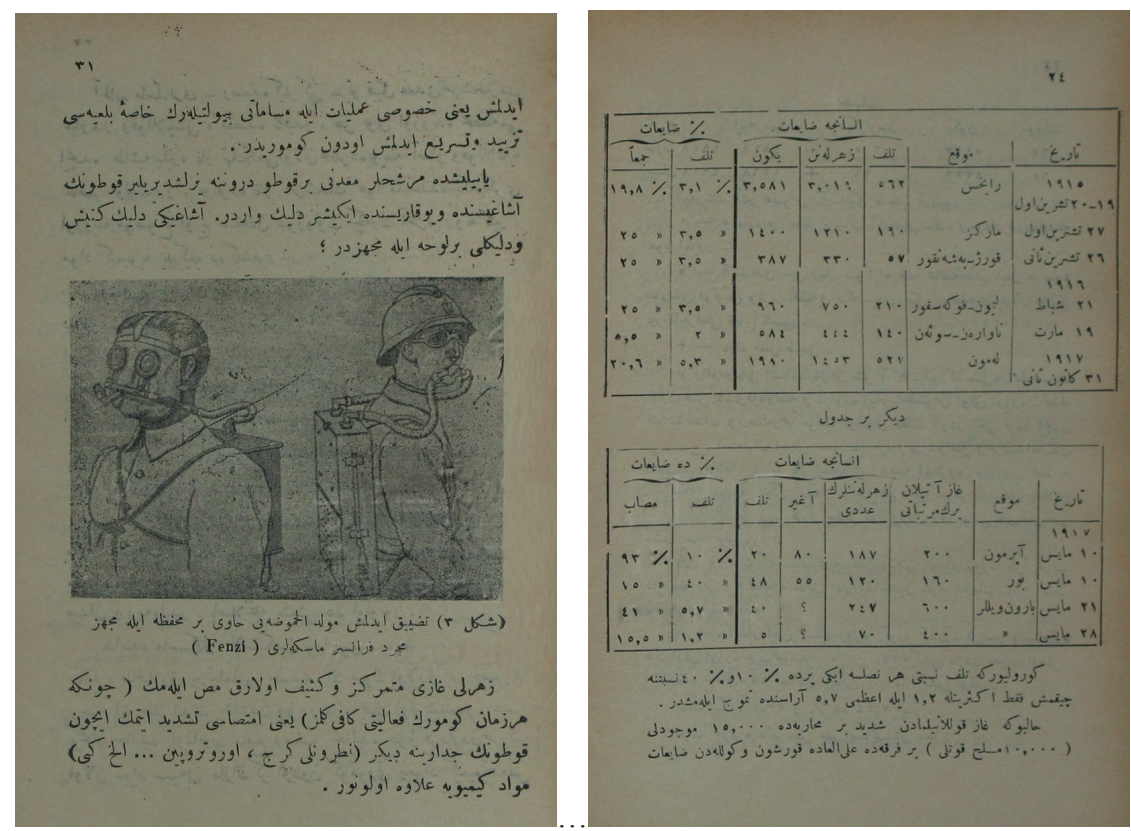

Şekil 2.3. ve 2.4. Hasan Kadri [Dirim], Semli Gaz Muharebesi ve Hastalıklarl (1926), s. 31, 24 (İstanbul Büyükşehir Belediyesi Atatürk Kitaplığ1 K.01780/ 358.34 has 1926 k.1/1). 
5 Ağustos 1931 tarihinde Büyük Erkânı Harbiye Reisi [Genelkurmay Başkanı] Müşir [Mareşal] Fevzi [Çakmak] Paşa (1876-1950), Halk İçin Havaya Karşı Korunma Talimatı başlıklı "kimyevî zehirli maddeler taarruzlarına karşı korunmayı öğreten” tüm resmi ve özel kurumlar ve halk tarafından uygulanmak üzere bir başemir yayınlamıştır. Başemir, altı bölümden oluşmakta olup ilk bölümde yeni savaş düzeninden bahsedilmiş ve savaşların artık sadece cephede değil ülkenin tamamında yapılacağı yani bir "millet harbi” olduğu vurgulanmıştır. ${ }^{21}$ Diğer bölümlerde sırasıyla; hava taarruz araçları, hava taarruzlarına karşı korunma yöntemleri, havaya karşı korunma tedbirleri ve teşkilleri, seferberlik hazırlıklarında ve düşman uçaklarının taarruzları halinde alınacak tedbirlerden söz edilmektedir.

1931 yılında Ankara'da askeri personel için zehirli gazlardan korunma kursları açılmıştır. 1932 yılından sonra ise bu kurslar Ankara dışındaki askeri birliklere de verilmeye başlanmıştır. ${ }^{22}$ 10 Mayıs 1932 tarihinde 14 ülkenin katıldığı Silahları Kaldırma Umumî Konferansı'nda zehirli gazların kullanımı tekrar gündeme gelmiş ve konferansa Türkiye adına katılan Hariciye Vekili Tevfik Rüştü Aras (1883-1972), Başvekâlete ayrıntılı bir rapor sunmuştur. Raporda olası bir saldırı karşısında ordunun ve halkın hazırlıklı olması gerektiği vurgulanmıştır. ${ }^{23}$

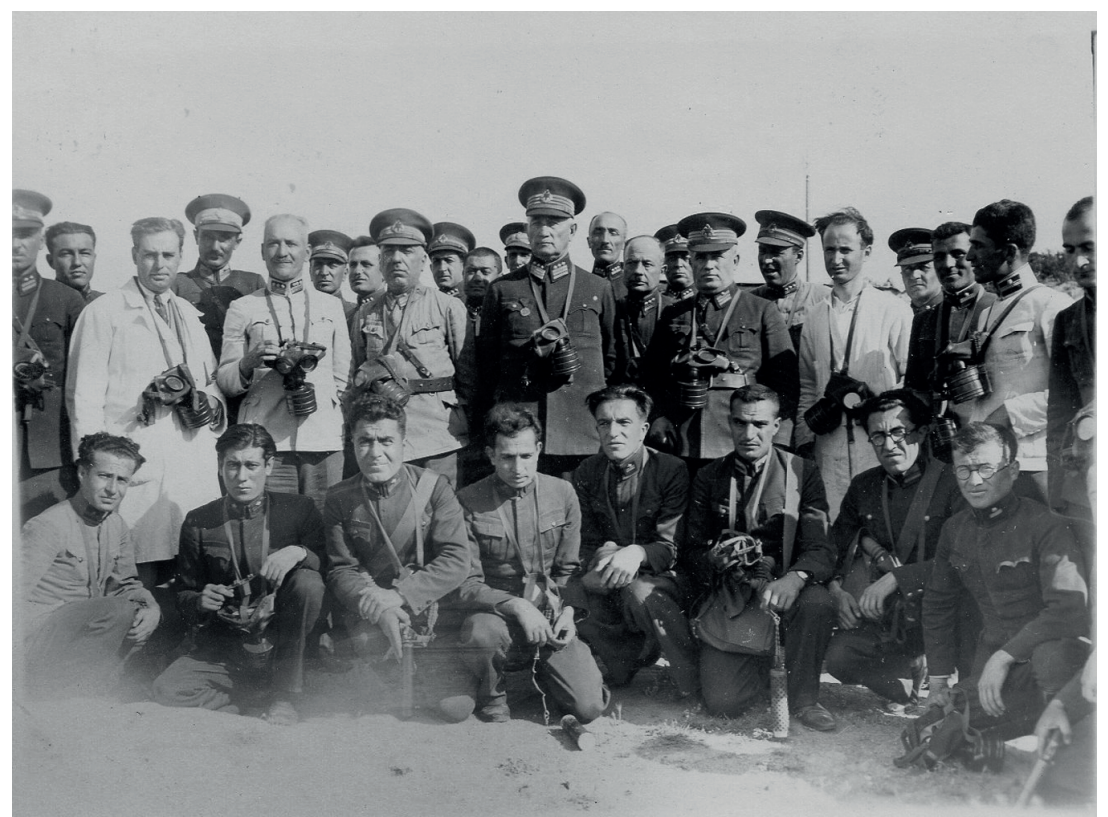

Şekil 3.1. 1932 yılından askerler tarafından yapılan bir zehirli gaz taarruzu tatbikatı (Eyüp Talha Kocacık Koleksiyonu).

21 Halk İçin Havaya Karşı Korunma Talimatı D. 86 (Ankara: Büyük Erkânıharbiye Reisliği Matbaası, 1931), 5-6.

22 Sabit Çetin, “İkinci Dünya Savaşı'nda İstanbul ve Trakya'da Alınan Tedbirler: Pasif Korunma ve Tahliye” (Yüksek Lisans tezi, Ankara Üniversitesi, 2008), 15.

23 Kandal, "Zehirli Gaz," 553. 


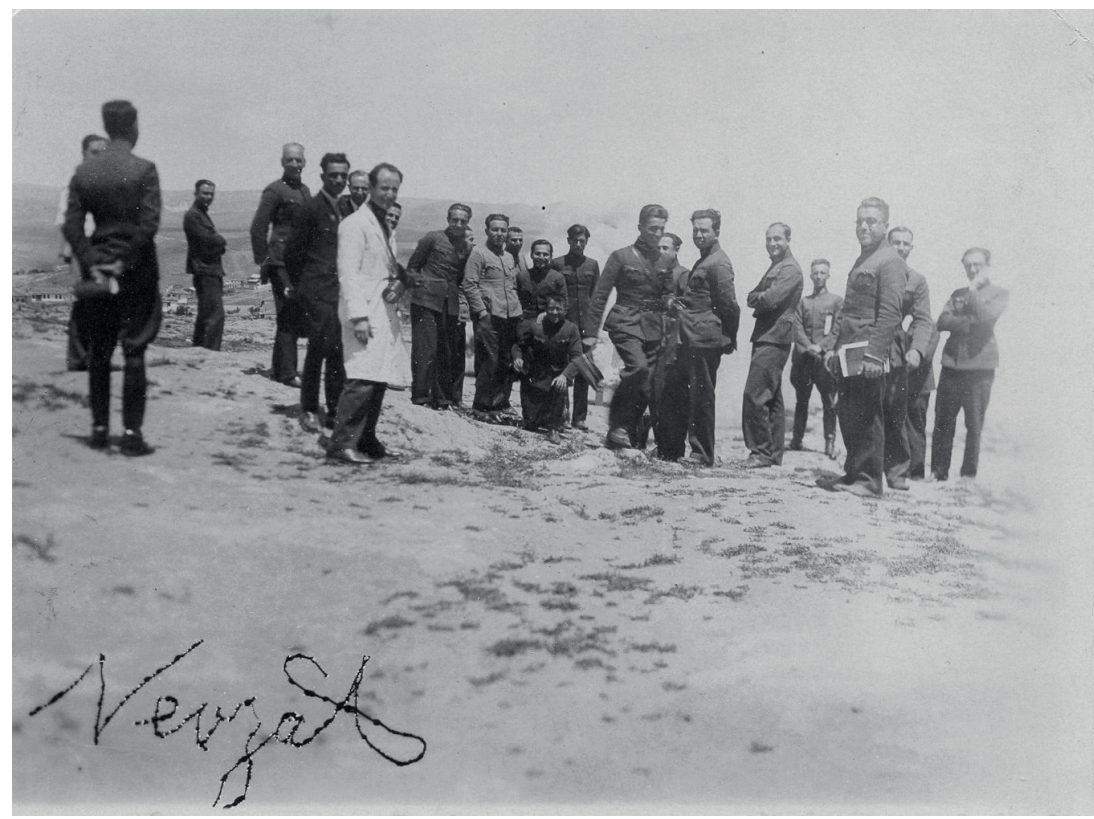

Şekil 3.2. 1932 yılından askerler tarafından yapılan bir zehirli gaz taarruzu tatbikatı (Eyüp Talha Kocacık Koleksiyonu).

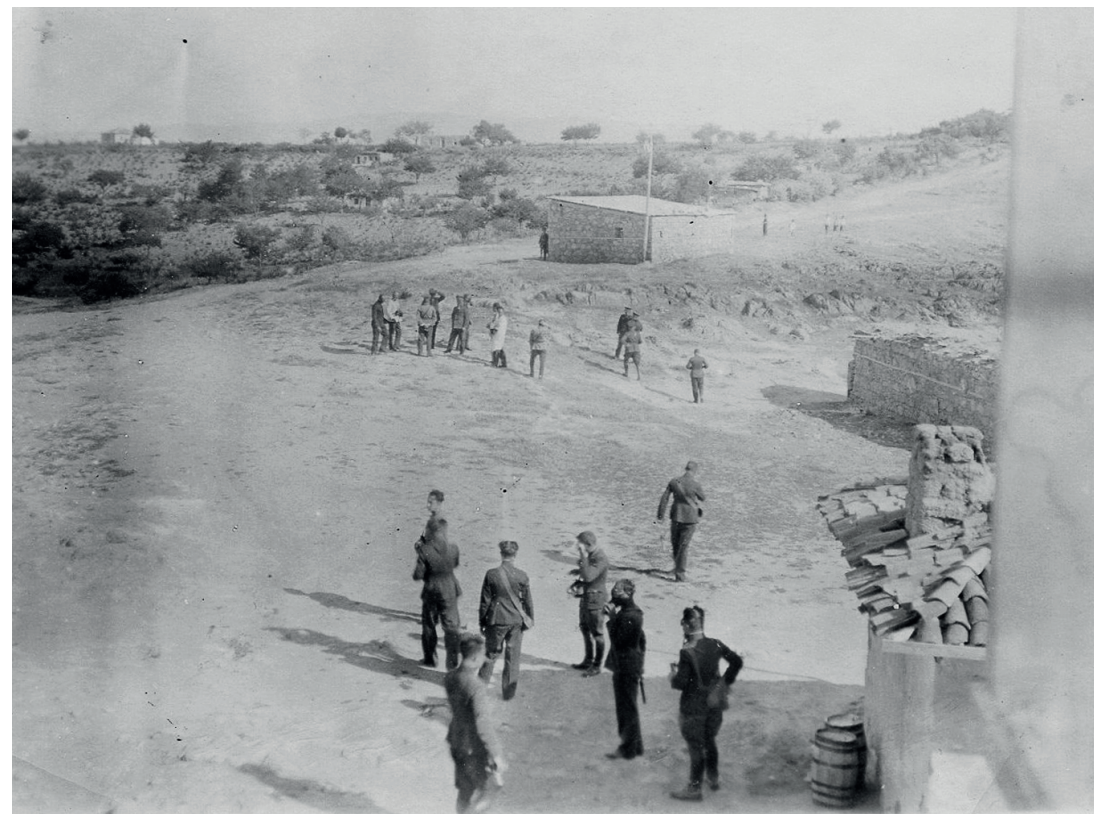

Şekil 3.3. 1932 yılında askerler tarafından yapılan bir zehirli gaz taarruzu tatbikatı (Eyüp Talha Kocacık Koleksiyonu). 


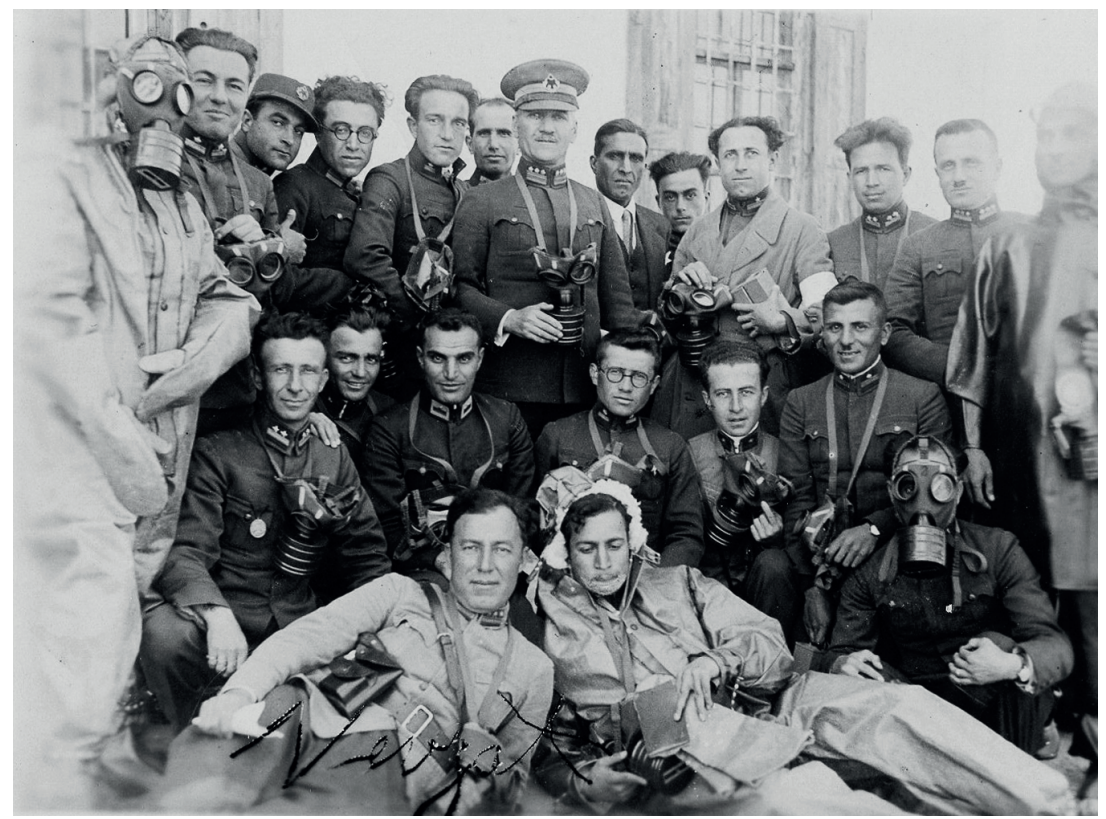

Şekil 3.4. 1932 yılında askerler tarafından yapılan bir zehirli gaz taarruzu tatbikatı (Eyüp Talha Kocacık Koleksiyonu).

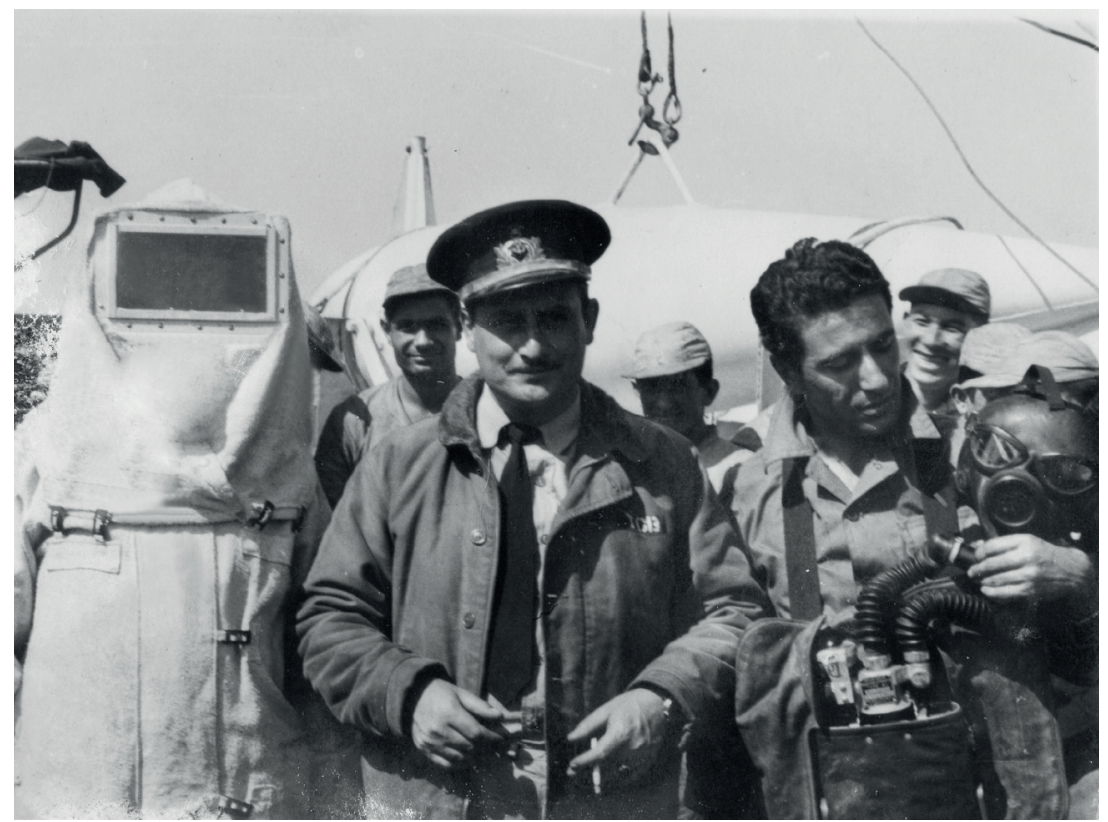

Şekil 3.5. 1930'lu yıllar askerler tarafından yapılan bir zehirli gaz tatbikatı (Eyüp Talha Kocacık Koleksiyonu). 
Ülkede bu tip talimatnameler ve kitapların yayınlanıyor olması, genel bir kimya savaşı dönemi hissiyatının uyandığını göstermektedir. Gazete ve dergilerde kimya savaşına yönelik yazılar yazılmış ve gaz konusu daima gündemde tutulmuştur. Gazetelerde yabancı ülkelerde yapılan gaz çalışmalarıyla ilgi manşetler atılmış ve haberler yayınlanmıştır. ${ }^{24}$ Türk Eczacıları Cemiyeti'nin yayın organı olan Türk Eczacı Âlemi dergisinde Eczacı Kimyager Fuad Mehmet [Mirel]'in yazığ 1 "Kimya-yı Harb" başlıklı dizi yazı1 ${ }^{25}$ ile, daha sonradan kurulan Türk Farmakoloğ Birliği’nin dergisi olan Farmakoloğ dergisinde de Eczacı Kimyager Yüzbaşı Mehmet Arif [Tekman] $]^{26}$ tarafından 1932 yılında yazılan "Kimya Harbi”" başlıklı dizi yazılar bu hissiyata örnek gösterilebilir. ${ }^{27}$

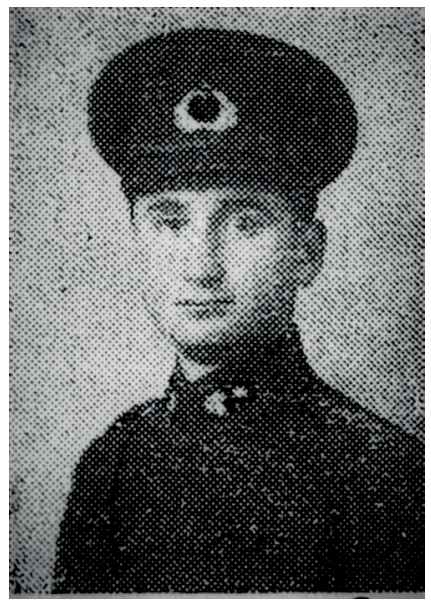

Şekil 4. Yüzbaşı Eczacı Kimyager Mehmet Arif [Tekman] ("Sıhhi Ayniyat Komisyonları,” Farmakoloğ 18, 9 (1948): 292.)

26 Haziran 1932 tarihinde Türkiye Büyük Millet Meclisi’nde Millî Müdafaa Vekâleti’nin bütçe görüşmeleri sırasında Artvin Mebusu Mehmet Ali [Okar] ${ }^{28}$ havacılığın önemi konusunda bir konuşma yapmıştır. Konuşmasında zehirli gazların önemine vurgu yapan şu

24 M. N., "Almanya Ne Yapabilir? Umumi Harpteki Askerî Dehadan Korkuluyor,” Cumhuriyet, 3 Teşrin-i Evvel [Ekim] 1932, 5.

25 Fuad Mehmet [Mirel], "Kimya-yı Harb," Türk Eczacl Âlemi 1, 1-2 (1928): 21-29.

26 Mehmet Arif[Tekman], 1927 yılından Eczacı Mektebi’nden mezun olmuş ve Tıbbiye Mektebi Müzakereciliğine atanmıştır. Ardından Gülhane'deki kimya laboratuvarına başasistan olan Arif Bey, buradaki sınavı başarıp uzman olduktan sonra, bir yll Tokat'ta görev yapmış ve sonra İstanbul'a dönmüştür. Bkz. "Meslek Haberleri," Farmakoloğ 4, 7-9 (1934): 900. Mehmet Arif [Tekman] daha sonra Mamak Gazdan Korunmaevi Kimyahane direktörlüğe atanmıştır. Bu görevindeyken, zehirli gaz kimyası konusundan eğitim almak üzere Avrupa'ya gönderilmiştir. "Meslek Haberleri," Farmakoloğ 8, 10-13 (1938): 131-132.

27 Eyüp Talha Kocacık, Farmakoloğ Dergisinin Özetli Bibliyoğrafyast ve İncelemesi (İstanbul: Eczacılık Tarihi Araştırma Derneği, 2016), 29, 32, 36.

28 Mehmet Ali [Okar], 1880 yllından Selanik’te doğmuştur. Yüzbaşı olan Mehmet Ali Bey, Buca Belediye Başkanlığı yapmıştır. III. ve IV. Dönem Artvin Milletvekilidir. 4. Mecidî Nişanı ve Almanya'dan verilen 2. Sınıf Demir Kızılhaç Madalyası sahibidir. 17.07.1935 tarihinden vefat etmiştir. Bkz. TBMM. Albümü 19202010, 1. Cilt 1920-1950, yay haz. Sema Yıldırım ve Behçet Kemal Zeynel (Ankara: TBMM Basın ve Halkla İlişkiler Müdürlüğü, 2010), 189. 
sözleri sarf etmiştir: "Zehirli gazlar hakkında ahalimizin tenvir edilmesini ve bir gün -lâzım olursa- zehirli gaz hücumlarına karşı ne yolda nefislerini müdafaa edebileceklerini muhtelif teşkilâtımız vasıtasıyla gösterilmesini rica ediyorum." ${ }^{29}$

Türkiye'de zehirli gazlar üzerine resmi düzenlemelerin yapılmasından önce zehirli gazlar üzerine konferanslar verilmiştir. İlk önce Darülfünun Fen Fakültesi Müderrisi Ömer Şevket [Öncel] zehirli gazlar üzerine Darülfünun konferans salonundan dört bölüm halinde bir dizi konferans vermiştir. 20 Nisan 1933 tarihinden verilen ilk konferansa; Darülfünun müderrisleri, Tayyare ve Hilâl-i Ahmer Cemiyeti üyeleri, Hilâl-i Ahmer Hastabakıcı Mektebi talebeleri, Darülfünun talebeleri ile kadın, erkek ve çocuklar katılmıştır. ${ }^{30}$ Konferanslarda harp esnasında düşman tarafından atılan gazların insanlara nasıl etki edeceği, etkinin nasıl bertaraf edileceği, maskelerin nasıl takılacağı ve muhafaza edileceği ve zehirli gazların tanınma yöntemleri gibi zehirli gaz taarruzundan korunmaya yönelik bilgiler verilmiştir. Ayrıca konferanslarda gaz maskeleri ve gaz taarruzlarına yönelik filmler gösterilmiş ve Darülfünun bahçesinde gaz ve sis tecrübeleri yapılmıştır. ${ }^{31}$ Ömer Şevket [Öncel]'in konuşmasındaki şu sözü zehirli gaz konusunun diğer ülkelerde de ne derece dikkate alındığ 1 göstermesi açısından önemlidir: "Rusya'da mendili olmayan var, fakat maskesi olmayan yoktur." 32

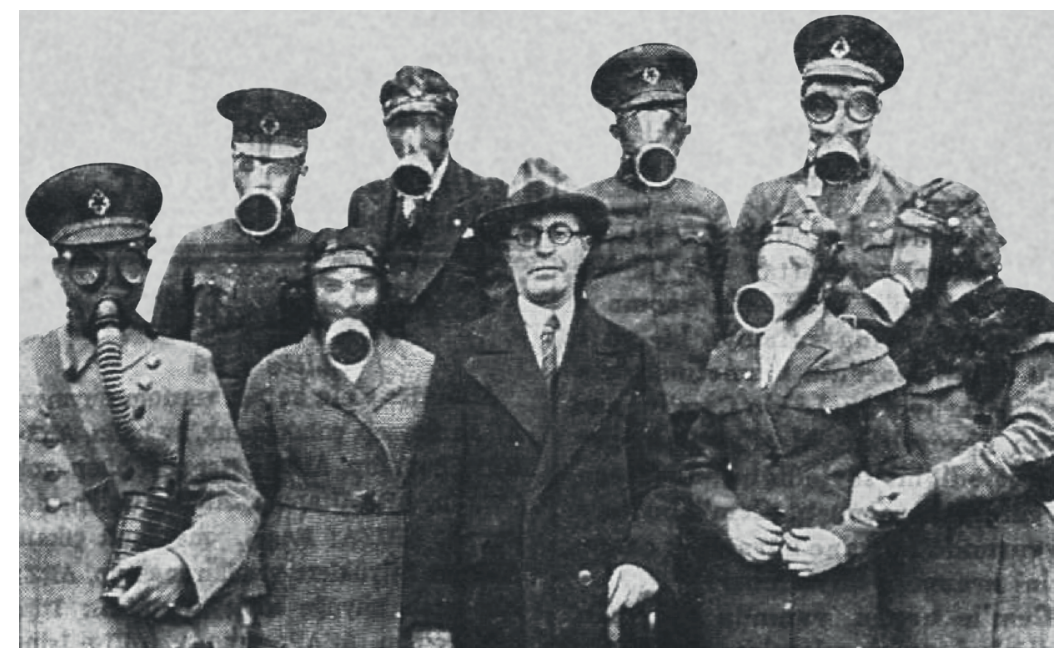

Şekil 5.1. Ömer Şevket [Öncel]'in Darülfünun'daki konferansından

(“Zehirli Gazlerden Korunma Çareleri,” Cumhuriyet, 28 Nisan 1933, 3.).

29 T.B.M.M. Zabıt Ceridesi, Devre 4, Cilt 9, İçtima 1, s. 341-344.

30 "Perşembe Günü Verilecek Konferanslar," Cumhuriyet, 25 Nisan 1933, 3; "Zehirli Gazlerden Korunma Çareleri," Cumhuriyet, 28 Nisan 1933, 3.

31 "Zehirli Gazler," Cumhuriyet, 26 Nisan 1933, 3; "Zehirli Gazlere Karşı Şimdiden Hazırlanmalı," Cumhuriyet, 5 Mayıs 1933, 1-2; “Darülfünun' da Dördüncü Gaz Konferans1," Cumhuriyet, 10 Mayıs 1933, 6; "Gazler ve Sisler," Cumhuriyet, 12 May1s 1933, 5.

32 “Zehirli Gazlerden Korunma Çareleri," Cumhuriyet, 28 Nisan 1933, 3. 


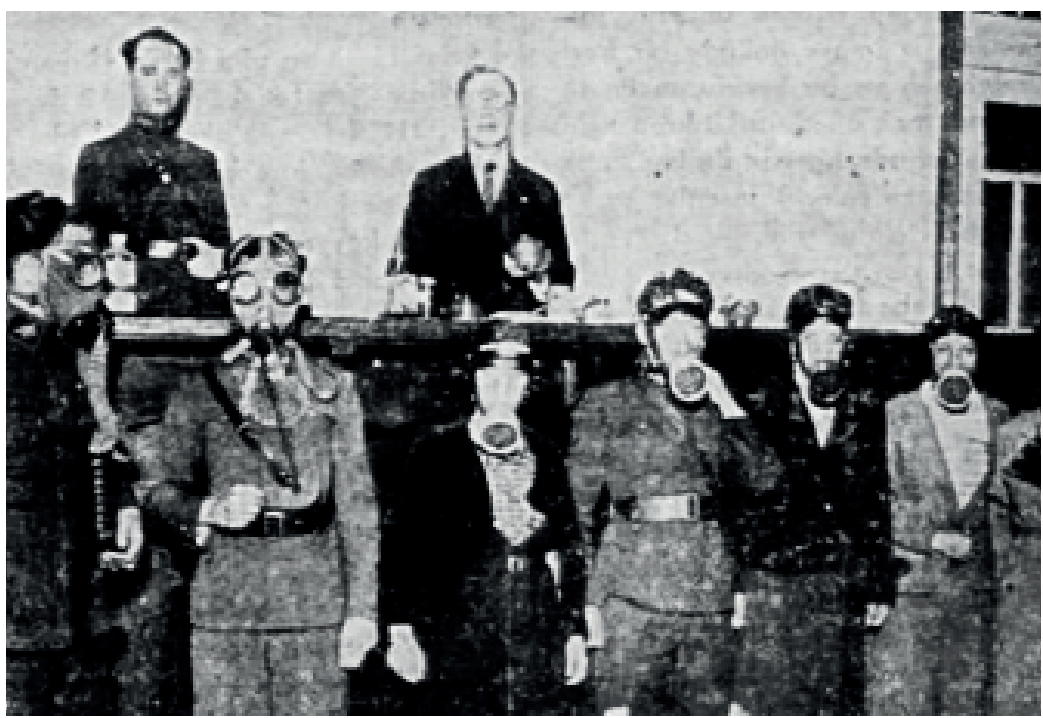

Şekil 5.2. Ömer Şevket [Öncel]'in Darülfünun'daki konferansından (“Zehirli Gazlere Karşı Şimdiden Hazırlanmalı,” Cumhuriyet, 5 Mayıs 1933, 1).

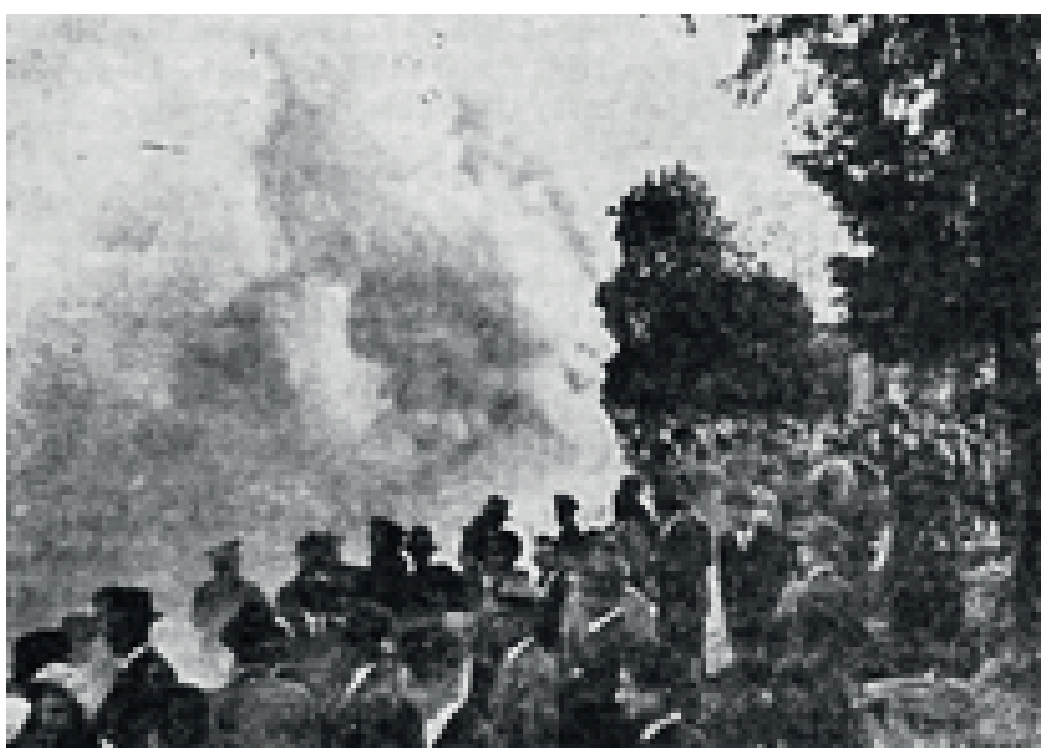

Şekil 5.3. Ömer Şevket [Öncel]'in Darülfünun'daki konferansından (“Gazler ve Sisler," Cumhuriyet, 12 May1s 1933, 5).

Ömer Şevket [Öncel]'in Darülfünun'da verdiği gaz konferanslarının bir benzeri de 1933 yılından Ankara' da yapılmıştır. Sıhhiye Müfettişi Miralay Doktor Mazlum [Boysan], Ankara 
Orduevi'nde milletvekillerine, askerlere, memurlara ve halka yönelik zehirli gaz konferansı vermiştir. Konferansta zehirli gazların kullanımının tarihi, yabancı ülkelerdeki zehirli gazlarla ilgili yapılan çalışmalar, ${ }^{33}$ gazların tanınması, gazlardan korunma yöntemleri ${ }^{34}$ gibi konular üzerinden durulmuştur. Mazlum [Boysan]'ın verdiği bu konferanslar daha sonra Askeri Sıhhiye Mecmuası'nda makale olarak yayınlamıştır.

1935 yılında da Eskişehir'de Doktor Nuri Kutkan tarafından dizi halinde üç konferans verilmiştir. Nuri Kutkan aynı zamanda Eskişehir Hilâl-i Ahmer [Kızılay] Kurumu'nun başkanlığını da yaptığından vermiş olduğu bu konferanslarda anlattıklarını kitap ${ }^{35}$ olarak bastırmış ve gelirini Kızılay’a bırakmıştır. Kutkan, birinci konferansında gazların tarihçesi, dünya savaşında gazların nasıl kullanıldığı, gelecek savaşlarda gazların kullanılma ihtimali ${ }^{36}$ üzerinden dururken, ikinci konferansında gaz çeşitleri ve gazların tanınması gibi hususlar ${ }^{37}$ ve üçüncü konferansında da gazdan korunma usulleri, gaz maskeleri, gaz elbiseleri, sığınaklar gibi konuları anlatmıştır. ${ }^{38}$

Ülke gündeminin tam ortasında duran zehirli gaz konusu üzerine devlet yetkililerin yanı sıra sivil vatandaşların da birtakım hazırlıklar yaptığı dikkatlerden kaçmaz. İzmirli Kimyager Abdüsselam Akgünlü zehirli gazlara karşı ürettiğini iddia ettiği ilaç için Ankara'da bir komisyona çağırılmış ve komisyonda ilacın hiçbir işe yaramadığı tespit edilmiştir. ${ }^{39}$ Keçiborlu tren istasyon memuru Halil Hamdi Çoburoğlu zehirli gazdan korunmaya yarayan bir elbise ürettiği ve ithal edilen elbiselere oranla çok uygun bir fiyata imal edilebileceği bilgisini paylaşmıştır. Yetkililer ise bu kumaşın denendiği ve son derece olumlu netice verdiğini kaydetmişlerdir. ${ }^{40}$ Halil Hamdi Bey'in bu icadı önce olumlu bulunmuşsa da daha sonra bu kumaşla ilgili herhangi bir bilgiye ve Halil Hamdi Bey'in adına rastlanılmamıştır.

\section{Zehirli Gazlar ve Hava Taarruzları Konulu Kanun ve Talimatnameler}

Büyük Erkânı Harbiye Reisliği tarafından 5 Ağustos 1931 tarihinde yayınlanan Halk İçin Havaya Karşı Korunma Talimatı'ndan sonra hava taarruzu ve gaz muharebesi üzerine bazı kanun ve talimatnameler çıkartılmaya başlanmıştır. Fevzi [Çakmak] Paşa imzalı bu talimattan hareketle 1934 yılında Büyük Erkânı Harbiye Reisliği tarafından Dahiliye, Milli Müdafaa, Sıhhat ve İçtimai Muavenet, Maarif ve Nafia Vekâletlerine ve Askerî Sıhhiye Müfettişliği’ne

33 Mazlum [Boysan], "Zehirli Gazlar ve Biz,” 152-153.

34 Mazlum [Boysan], "Zehirli Gazlar ve Biz," Askeri Sthhiye Mecmuast 62, 3 (1933): 179-180.

35 Nuri Kutkan, Zehirli Gaz Konferanslarım (Eskişehir: Yıldız Basımevi, 1935).

36 Kutkan, Zehirli Gaz, 5-14.

37 A.e., 15-41.

38 A.e., 41-60.

39 "Boşa Çıkan Zehirli Gaz İlacı," Cumhuriyet, 10 Mart 1934, 2.

40 "Bir Şimendifer Memurunun İcad1," Cumhuriyet, 21 Haziran 1934, 3; "Zehirli Gaz İçin Yapılan Elbise: Bir Türk Sanatkârının İcadı Beğenildi,” Cumhuriyet, 30 Haziran 1934, 4. 
gönderilmek üzere başka bir resmi yazı yazılmıştır. Bu yazıyı alan ilgili makamlar da kendilerine bağlı bulunan ve konuyla ilgili olan kurumlara bu yazıyı göndermişlerdir. Maarif Vekâleti'nden 20 Ağustos 1934 tarihinde İstanbul Üniversitesi Rektörlüğü’ne gönderilen yazı EK 1'de verilmiştir. Yazının içeriğine bakıldığında şu hususlar öne çıkmaktadır:

Milli seferberlik talimatnamesi uyarınca 1 Mayıs 1934 tarihinde Ankara'da açılmış olan Askerî Gaz Kursu'na her vilayetten bir sivil hekimin katılması zorunlu tutulmuşsa da maddi sebeplerden dolayı kursa tam katılım sağlanamamıştır. Ankara'daki askerî gaz kursuna sivil teşkilâta bağlı Ankara'dan bir kimyager, dört doktor, Kırıkkale'den bir kimyager, Ankara ve İstanbul İtfaiye teşkilâtlarından dört memur, Ankara'dan ve jandarma mekteplerinden altı jandarma, Devlet Demir Yolları'ndan üç doktor, dört mühendis ile İstanbul'dan bir profesör iştirak etmiştir. 27 Mayıs 1934 tarihinde yeni bir yazı ile kursa katılımın Özel İdare ve Belediyelere düşen maddi yükünü hafifletmek için bazı uygulamalar üzerinde durulmuştur.

1- İstanbul Üniversitesi Tip Fakültesi'nde bir kürsü kurularak kimya ve tıp eğitimi alan öğrenciler ile daha önceden bu bölümlerden mezun olan hekim ve kimyagerlerin muharebe gazları ve mikrop harbi için eğitilmesi planlanmıştır.

2- Tüm okullarda ve halkevlerinde gençlere ve yurttaşlara her sene muharebe gazlarını ve mikrop harbini anlatacak konferansların düzenlenmesi planlanmıştır.

3- Gaz taarruzlarına karşı halkın emniyet ve sıhhatini korumakla mükellef idare amirlerinin gaz kursundan geçirilmesi planlanmıştır.

4- Muharebe gazları ve hastalık yapıcı mikroplara karşı koruyucu önlemler almak için gerekli aletlerin temin edilerek demiryolu güzergâhındaki şehir ve kasabalarda hazır bulundurması planlanmıştır.

5- Gezici ve sabit gaz sergileriyle halkın bilgilendirilmesi planlanmıştır.

6- Radyo vasitasıyla zehirli gazlar ve korunması hakkında konferanslar verilmesi planlanmıştır.

7- Bütün bu tedbirlerin üzerine özel idare ve belediyelerin 1935 yılı bütçesine her vilayetten en az bir hekimin 1935 yılında Ankara'da yapılacak Askerî Gaz Kursu'na gönderilmesini sağlayacak tahsisatın ayrılması özel olarak istenmiştir.

7 Nisan 1934 tarihinde Zehirli Gazlarla Bunları Kullanmaya Mahsus Vasitaların Memlekete Sokulmasinin ve Memlekette Yaptırlmasinin Men'i Hakkında Kanun kabul edilmiştir. ${ }^{41} \mathrm{Bu}$ kanunda zehirli gazlar ile bu gazları kullanmayı sağlayan araçların ülkeye sokulması yasaklanmış ve sadece Millî Müdafaa, Sıhhat ve İçtimaî Muavenet, Ziraat, Dahiliye ve Gümrük ve İnhisarlar Vekâletlerine lazım olanların ithaline izin verileceği hükmü getirilmiştir [Madde 1].

41 T.C. Resmi Gazete, sayı 2676, 15 Nisan 1934. 
14 Haziran 1935 tarihinde Kimya Harbinden Korunmaya Mahsus Malzeme Hakkında Kanun kabul edilmiştir. ${ }^{42} \mathrm{Bu}$ kanunda gazdan korunmaya yarayan her türlü malzemeyi ve maskeyi yurda getirme ve satma hakkı Kızılay Cemiyeti'ne verilmiştir [Madde 1]. Kızılay Cemiyeti tarafından kurulan fabrikada ${ }^{43}$ üretilen maske ve ürünlerin Sıhhat ve İçtimaî Muavenet Vekâleti ve diğer teşkilatlar tarafından alınması mecburiyeti getirilmiştir [Madde 2].

Dahiliye Vekâleti tarafından Havaya Karşı Korunma Komisyonlarının Vazifeleri Hakkında Talimat, ${ }^{44} 1935$ yılında Sıhhat ve İçtimaî Muavenet Vekâleti'nce Hava Taarruzlarına Karşı Korunmada Yurt Sıhhat İsleri Talimatı, ${ }^{45} 1936$ yılında yine Dahiliye Vekâleti tarafindan Savaş Zamanında Işılkların Söndürülmesi ve Karartılması Talimatnamesi yayınlanmıştır. ${ }^{46}$

1936 yılında Sıhhat ve İçtimaî Muavenet Vekâleti tarafından Vilayetlerde Açılacak Hava ve Zehirli Gazdan Korunma Kursları Hakkında Talimat yayınlanmıştır. ${ }^{47}$ Beş maddeden oluşan bu talimatta; kurslara kimlerin katılacağı ve kursları kimlerin vereceği, açılacak kursların müfredatları, kurslarda yapılacak olan tecrübelerin yöntemleri, ayrıca şehirlerde verilecek konferansların içeriği, tecrübelerde kullanılacak malzemenin tedariki, okutulacak kitaplar gibi birçok konu belirlenmiştir [Talimatın tam metni için bkz. EK 2].

11 Haziran 1937 tarihinde yurdun hava taarruzlarına karşı koruntma işlerinił tek elden yürütülmesini sağlamak amacıyla Hava Müdafaa Genel Komutanlığı Teşkili ve Vazifesi Hakkında Kanun çıkarılmıştır. ${ }^{48}$ Bu kanunla Genelkurmay Başkanlığı'na bağlı Hava Müdafaa Genel Komutanlığı kurulmuş olup, yurdun tamamında aktif ve pasif korunma hazırlıklarının bu komutanlık bünyesinde yapılması sağlanmıştır.

27 Haziran 1938 tarihinde Hava Taarruzlarına Karşı Korunma Kanunu çıkartılmıştır. ${ }^{49}$ $\mathrm{Bu}$ kanunla hava taarruzlarına karşı korunmak ve etkilerini azaltmak maksadıyla halk ve resmi, milli, özel teşekküller tedbirler almaya ve teşkilatlar oluşturmaya zorunlu tutulmuştur [Madde 1]. 15 yaşını doldurmuş ve 60 yaşını tamamlamamış bütün yurttaşlar, nizamnamelere göre hava karşı korunma bilgisi almaya ve yılda otuz saat ders ve talim görmeye mecbur tutulmuştur [Madde-7].

Bu kanunun uygulanmasına yönelik bazı nizamname ve talimatnameler de çıkartılmıştır. Bunlar; 1939 Şubat ayında çıkartılan Hava Taarruzlarına Karşı Işıkların Söndürülmesi ve

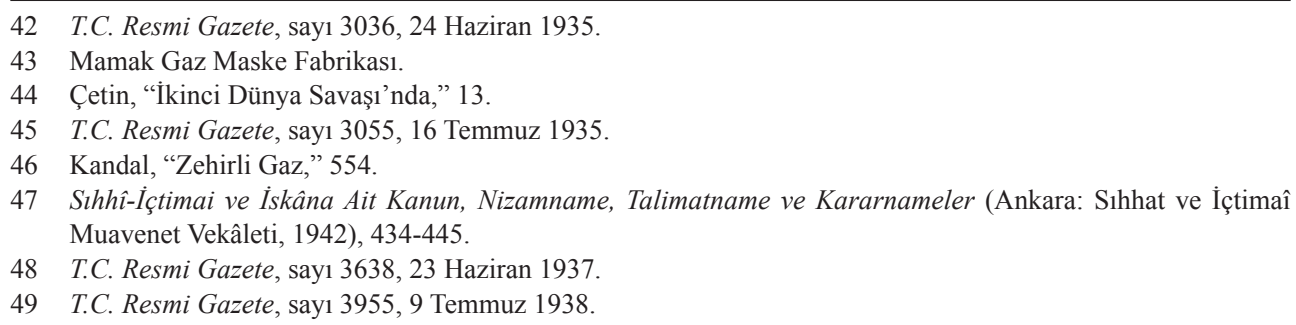


Karartılması Nizamnamesi ${ }^{50} 1939$ Nisan ayında çıkartılan Hava Taarruzlarına Karşı Pasif Korunma Nizamnamesi, ${ }^{51}$ Hava Hücumlarına Karşı Hayvanların ve Hayvanlardan Husule Gelen Yiyecek Maddelerinin Korunmasina Dair Talimatname ${ }^{52}$ ile Ticaret Gemilerinin Gaza Karşı Korunması Hakkında Nizamname, ${ }^{53} 1940$ Ocak ayında çıkartılan Yapılarda Pasif Korunma Bakımında Tatbik Olunacak Esaslar ve Slğınaklar Nizamnamesi ${ }^{54}$ ve 1940 Haziran ayında çıkartılan Şehir Planlarının Tanziminde ve Mühim Bina Yerlerinin Tayininde Tatbik Edilecek Pasif Korunma Şartlarina Dair Nizamname'dir. ${ }^{55}$

\section{Hava Hücumlarından Korunma Cemiyeti (1933)}

Eylül 1933 tarihinde İstanbul Valiliği'ne Hava Hücumlarindan Korunma Cemiyeti adında bir cemiyetin kurulması için müracaat edilmiştir. ${ }^{56} \mathrm{Cemiyet}$, hava hücumları ve zehirli gazlara karşı önlemler almak, halkı bilinçlendirmek ve hazırlıklara yol gösterme maksadıyla kurulmuştur. ${ }^{57}$ Cemiyetin beyannamesindeki şu sözler amacını tam olarak yansıtmaktadır: "Her müskülü sarsllmaz bir iman ile yenen ve bütün milletlerin takdir ve tahsinlerine mahzar olan asil halkımızın başaramayacağı hiçbir zorluk yoktur; yeter ki yapılacak ve yapılması lazım gelenler bilinsin de bu hedef etrafinda yurdumuza ve yuvalarımıza duyduğumuz bir sevgi ile toplanılsın. Hava Hücumlarından Korunma Cemiyeti'nin teşekkülündeki esas maksat yurdunu ve yuvasın seven yurttaşlara bu bilgiyi ve birikimi temindir." (Beyannamenin tam metni için bkz. EK 3)

Cemiyetin başkanlı̆̆ını Mütekait [Emekli] Erkânıharbiye Miralayı [Kurmay Albay] Mahmut Beliğ, genel sekreterliği ise Naci Bey üstlenmiştir. Cemiyetin merkezi İstanbul olmak üzere bazı şehirlerde şubeler açması planlanmıştır. Mahallelerde de hava hücumları ve zehirli gazlardan korunma hususunda görev yapacak gruplar oluşturulup, bu grupların kendi bölgelerinde "talim odaları" açarak tecrübeler yapması öngörülmüştür. $\mathrm{Bu}$ "talim odaları"nda kullanılması gerekecek malzemelerin cemiyet tarafindan sipariş ile getirtilmesi için çalışılmıştır. Cemiyetin nizamnamesi çok kısa bir sürede valilik tarafından onaylanmış ve çalışmalar başlamıştır. Cemiyet başkanı Mahmut Beliğ ve genel sekreteri Naci Bey Dolmabahçe Sarayı'nda Gazi Mustafa Kemal Paşa ile görüşü̈şler ve Gazi, bu konudaki çalışmaları teşvik ederek geliştirilmesi talimatını vermiş̧ir. ${ }^{58}$ Cemiyetin sembolü olarak da zehirli gazdan etkilenmiş bir vatandaşa müdahale eden özel elbiseli ve maskeli bir kadın resmi hazırlanmıştır.

50 T.C. Resmi Gazete, sayı 4142, 25 Şubat 1939.

51 T.C. Resmi Gazete, , say1 4178, 8 Nisan 1939.

52 T.C. Resmi Gazete, , say1 4186, 18 Nisan 1939.

53 T.C. Resmi Gazete, say1 4188, 20 Nisan 1939.

54 T.C. Resmi Gazete, say1 4418, 27 Kânunusani [Ocak] 1940.

55 T.C. Resmi Gazete, say1 4532, 11 Haziran 1940.

56 “Zehirli Gazlardan Korunma Cemiyeti," Cumhuriyet, 22 Eylül 1933, 2.

57 "Hava Hücumlarından Korunma Cemiyeti Beyannamesi," Cumhuriyet, 21 Teşrinievvel [Ekim] 1933, 6.

58 "Hava Koruma Cemiyeti Faaliyete Başliyor," Cumhuriyet, 30 Eylül 1933, 3. 


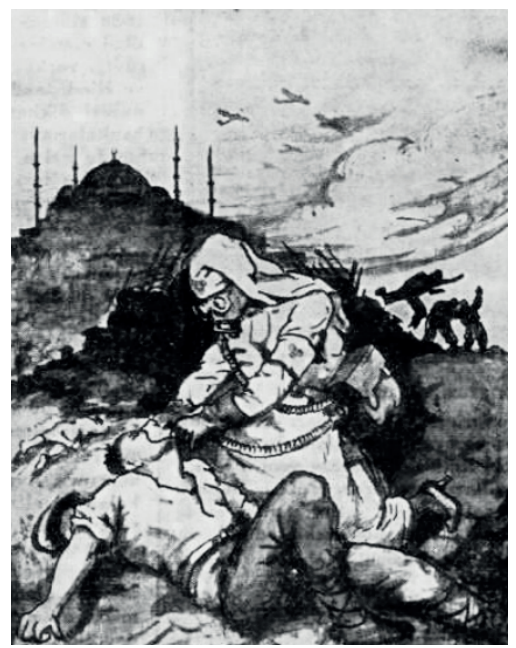

Şekil 6. Hava Hücumlarından Korunma Cemiyeti’nin sembolü

("Hava Koruma Cemiyeti Faaliyete Başliyor," Cumhuriyet, 30 Eylül 1933, 3.)

\section{Hava Hücumlarına Karşı Korunma Yerleri: Sığınaklar}

Binaların pasif korunmaya göre nasıl yapılacağı ve sığınaklarının nasıl olacağına dair hazırlanan Yapılarda Pasif Korunma Bakımında Tatbik Olunacak Esaslar ve Siğınaklar Nizamnamesi, ${ }^{59} 27$ Ocak 1940 tarihinde yürürlüğe girmiştir. Bu nizamnameden önce şehirlerde genel sığınaklar oluşturmak için birçok hazırlık yapılmıştır. ${ }^{60}$ Özellikle İstanbul'daki eski mahzen ve sarnıçları genel sığınaklara dönüştürmek için Avrupa'dan uzmanlar getirilmiştir. ${ }^{61}$

Yapılan incelemeler neticesinde İstanbul'da birçok yerde sığınaklar oluşturulmuştur. Beşiktaş ile Yıldız arasındaki mahzenlerin İstanbul'daki tüm memurları muhafaza edecek kadar geniş olduğu tespit edilmiş ve bunları sığınak haline getirmek için çalışmalar yapılmıştır. Ayrıca, İstanbul'da nüfusun yoğun olduğu Beyoğlu, Fatih ve Eminönü kazalarına dörder, diğer kazalara da ikişer sığınak inşası kararı alınmıştır. ${ }^{62}$

Şehrin sokaklarına, sığınakların yerini gösteren levhalar konularak üzerlerine "umumi sığınağa gider", “sığınağa gider” ifadeleri yazılmıştır. Sadece İstanbul'da 1941 yılına kadar oluşturulan sı̆̆ınak sayısı 12.500 'e ulaşmıştır. ${ }^{63}$

59 T.C. Resmi Gazete, sayı 4418, 27 Kânunusani [Ocak] 1940.

60 "Hava Hücumlarına Karşı Şehirlerde Sı̆̆ınaklar, Gaz Odaları Yapılacak," Cumhuriyet, 5 Kânunusani [Ocak] $1934,1,3$.

61 “Zehirli Gazlere Karşı Halkı Koruma Yerleri," Cumhuriyet, 24 Temmuz 1935, 1, 7; "Hava Tehlikesine Karşı Hazırlıklı Bulunacağız," Cumhuriyet, 26 Temmuz 1935, 1, 5.

62 Umut Karabulut, "Davetsiz Misafiri Beklerken İkinci Dünya Savaşı Türkiye’sinde Pasif Güvenlik Önlemleri (1939-1940)," Çăgdaş Türkiye Tarihi Araştırmaları Dergisi 14, 28 (Bahar 2014): 213.

63 Çağatay Benhür ve Mahir Selim Akçakaya, "İkinci Dünya Savaşı Sırasında Konya'da Alınan Askerî Önlemler," Gazi Akademik Bakış 5, 9 (Kış 2011): 180. 


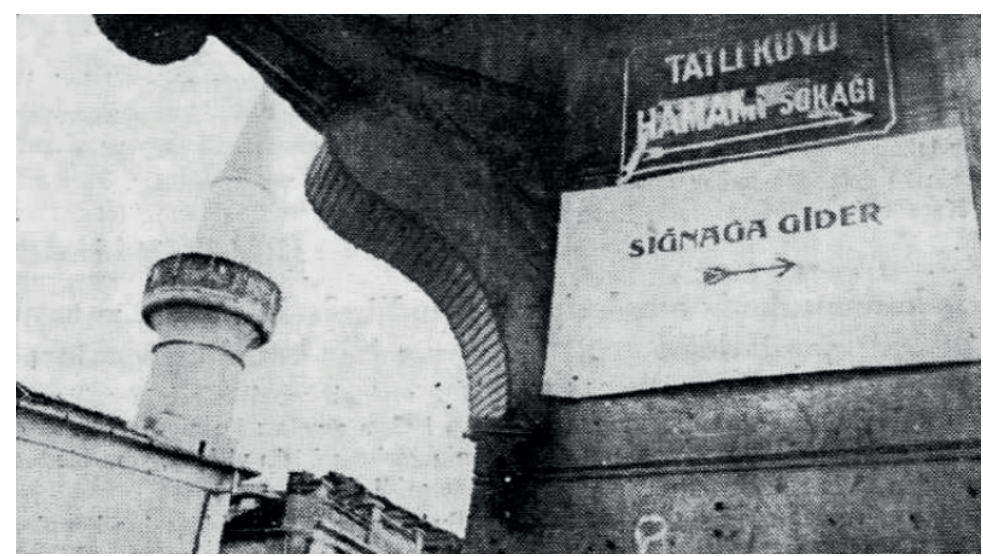

Şekil 7.1. İstanbul Fatih’teki bir sokakta sığınağın yönünü gösterir levha (“Hava Hücumlarına Karşı Alınan Korunma Tedbirleri," Cumhuriyet, 14 Ağustos 1939, 1.)

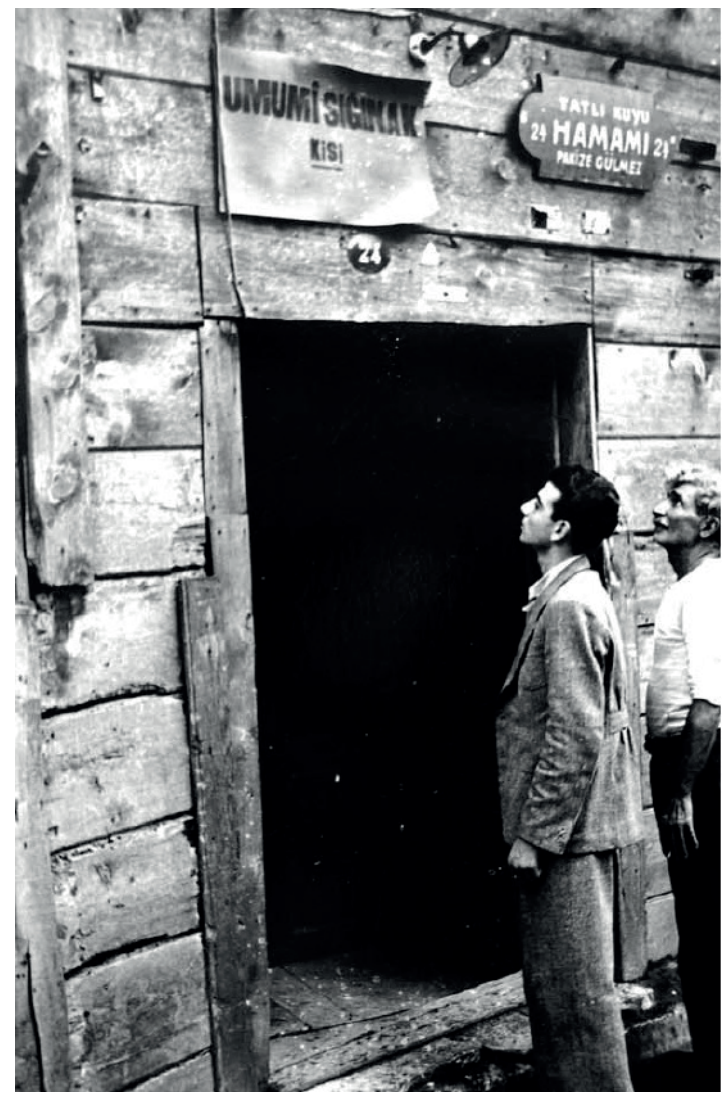

Şekil 7.2. İstanbul, Fatih’teki bir sığınak (Toprak, “Türkiye'de Barış Ortamında,” 41.) 
Sığınaklar yapıldıktan sonra farklı tarihlerde hava taarruzu tatbikatları yapılmış ve halkın olası bir saldırı anında nasıl yönlendirilmesi gerektiği denenmiştir. İstanbul Valiliği bu tatbikatlar ile ilgili emirler yayınlamıştır. Emirde tatbikatın ne zaman başlayacağı, tatbikat sırasında yapılması gerekenler ve bitiş saati gibi bilgiler bulunmaktadır. ${ }^{64}$ Tatbikatlarda, sığınakların ve pasif korunma yöntemlerinin önemi vurgulanarak halk bilinçlendirilmeye çalışılmıştır.

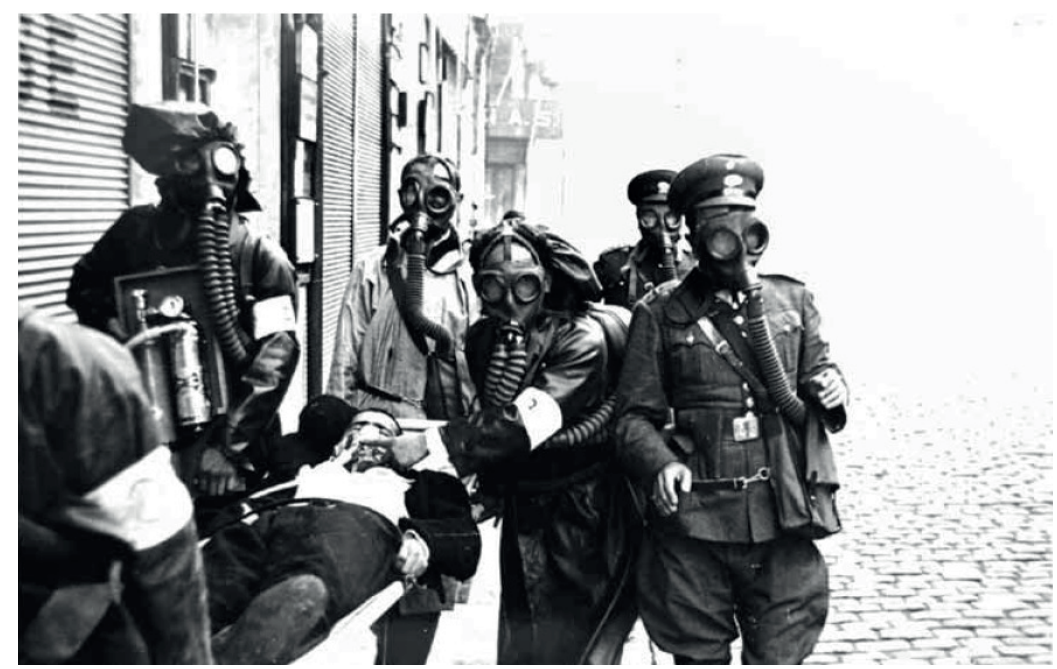

Şekil 8.1. İstanbul'da yapılan bir tatbikat (Toprak, "Türkiye'de Barış Ortamında,” 46).

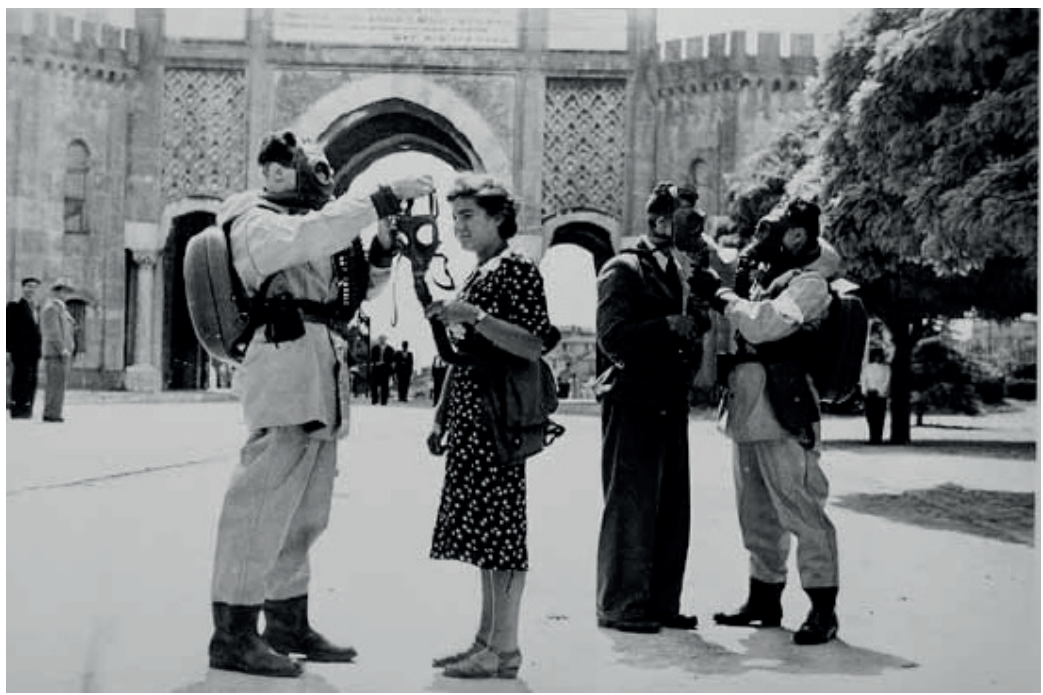

Şekil 8.2. İstanbul'da yapılan bir tatbikat (Toprak, "Türkiye'de Barış Ortamında," 42).

64 "Hava Hücumlarına Karşı Alınan Korunma Tedbirleri," Cumhuriyet, 14 Ağustos 1939, 3. 
Otuzlu yılların sonlarına doğru artan savaş tehlikesi sığınak yapılmasını arttırmışsa da 1942'den sonra azalan savaş ihtimali sığınakların önemini kaybetmesine yol açmıştır. Önemini kaybeden bu yerlerin zamanla çöp alanına dönüşmesi buraların temizlenmesi problemini de beraberinden getirmiştir. ${ }^{65}$

\section{Mamak Gaz Maske Fabrikası}

1927 yılında askeri alanda kullanılmak üzere bir kimya laboratuvarı açılması için çalışmalara başlanmış ve 22 Temmuz 1933 tarihinde Mamak’ta bir kimya laboratuvarı açılmıştır. Bu laboratuvarda maske üretimi çalışmaları yapılmıştır. ${ }^{66} 14$ Haziran 1935 tarihinde çıkarılan Kimya Harbinden Korunmaya Mahsus Malzeme Hakkında Kanun ile zehirli gazlardan korunmaya yarayan her türlü malzemenin ve maskelerin yurda sokulmas1, satılması ve bir maske fabrikasının kurulma hakkı Kızılay Cemiyeti’ne verilmiştir.

Bu kanundan sonra askeri ve sivil amaca hizmet eden bir maske fabrikasının Mamak’ta bulunan kimya laboratuvarının yanında devlete ait olan 150.000 metrekarelik araziye kurulması kararlaştırılmıştır. Fabrikanın kuruluş kanunu 6 Ekim 1933 'te yürürlüğe girmiştir. ${ }^{67}$

Mamak Gaz Maske Fabrikası 31 Ekim 1935 tarihinde büyük bir törenle açılmış ve üretime başlamıştır. ${ }^{68}$ Fabrikanın açılışını yapan Başbakan İsmet İnönü, yaptığı konuşmada, maskelerin ve maske fabrikasının ne derece önemsendiğini vurgulamıştır:

Bir buçuk yıldan beri, böyle bir fabrikanın kurulmasına çok ehemmiyet verdik. Maske, ordu silahı halinden çoktan çıktı ve her evde bulunması gerekli bir eşya halini aldı. $\mathrm{Bu}$ sebepledir ki bu fabrikanın memlekete hizmetleriyle çok övüneceğiz.

İsmet İnönü, burada gaz maskesi meselesinin, bir halk meselesi, bir vatandaş meselesi addedildiğini ve bunun için işi Kızılay’a verdiklerini belirtmiş ve Kızılay kurumu ile değerli başkanı Refik Saydam'ın bu önemli işi muvaffakiyetle başardığını ifade etmiştir. ${ }^{69}$

65 Çetin, "İkinci Dünya Savaşı'nda," 56.

66 Hüsnü Özlü, "II. Dünya Savaşında Günümüze Türkiye'de Savunma Sanayii'nin Gelişimi (1939-1990)" (Doktora tezi, Dokuz Eylül Üniversitesi, 2006), 24.

67 Çetin, "İkinci Dünya Savaşı'nda," 21.

68 "Maske Fabrikamız Dün Çalışmaya Başladı," Cumhuriyet, 1 İkinci Teşrin [Kasım] 1935, 1.

69 “Ankara Mamak'ta Kurulan Zehirli Gaz Maskesi Fabrikası'nın Açılış Töreninde Yapılan Konuşma," erişim 20 Haziran 2019, http://www.ismetinonu.org.tr/ismet-inonu-1933-1938.htm\#_ftn137 

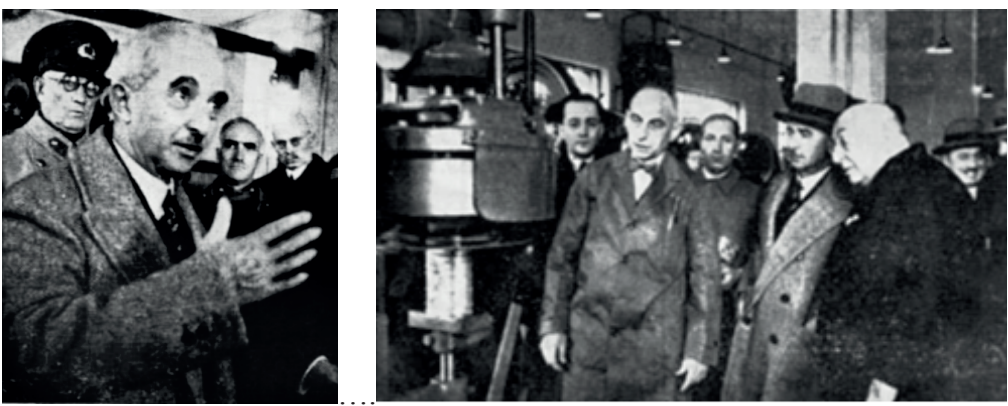

Şekil 9.1. (solda). Mamak Gaz Maske Fabrikası'nın açı1ış töreninde Başbakan İsmet İnönü (Cumhuriyet, 2 İkinci Teşrin [Kasım] 1935, 1); Şekil 9.2. (sağda). Mamak Gaz Maske Fabrikası'nın açı1ış töreninde Başbakan İsmet İnönü ve Refik Saydam (Cumhuriyet, 2 İkinci Teşrin [Kasım] 1935, 1).

31 Ekim 1935 tarihinde açılan maske fabrikası 1938 yılında halk için maske üretip satmaya başlamıştır. ${ }^{70}$ Fabrikanın açıldığı tarihten yaklaşık üç yıl sonra halk tipi maskelerin satışa sunulması, üretimde önceliğin askeri kullanım amaçlı maskelere verilmiş olmasıyla açıklanabilir. Halk tipi maskeler Kızılay merkezlerinde Aralık 1938 başından itibaren 6 liraya satışa çıkarılmıştır. ${ }^{71}$ Her vatandaşın maskeye sahip olması özendirilmeye çalışılmış, gazetelerde, maskelerin nasıl takılacağı, nelere dikkat edileceği ile ilgili makaleler yayınlanmıştır. ${ }^{72}$

Okullarda öğrencilere maske alma zorunluğu getirilmiş, birden fazla çocuğu olan ailelerin maddi sıkıntıya düşmelerini önlemek için taksitle maske almaları sağlanmıştır. Hükümet memurların maske temin etmeleri için bir genelge yayımlamış, memurlara üç taksitle altı liraya maske alınabileceği duyurulmuştur. ${ }^{73}$

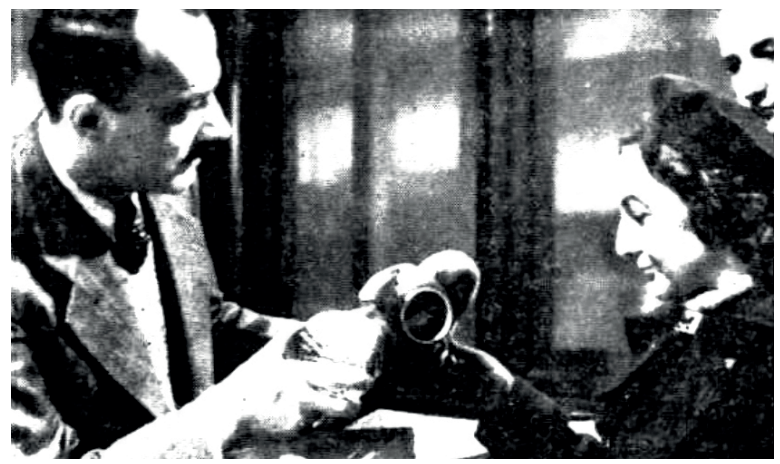

Şekil 10. Kızılay merkezinde yapılan bir maske satışı

(“"Halk Maskeleri Satış1," Cumhuriyet, 10 Birinci Kanun [Aralık] 1938, 5).

70 "Maske Fabrikası Yakında Halk İçin Maske İmaline Başlıyor," Cumhuriyet, 27 İkinci Teşrin [Kasım] 1938, 2.

71 "Gaz Maskeleri," Cumhuriyet, 9 Birinci Kanun [Aralık] 1938, s. 5; "Halk Maskeleri Satışı," Cumhuriyet, 10 Birinci Kanun [Aralık] 1938, 11; "Halk Maskeleri Satış1," Akşam, 22 Nisan 1939, 16.

72 Selahattin Güngör, "Gaz Maskesi Satışı Hararetle Devam Ediyor," Cumhuriyet, 20 Birinci Kanun [Aralık] 1938, 5.

73 Karabulut, "Davetsiz Misafiri Beklerken," 211. 
Gaz maskelerinin yeterli sayıda üretilip halka satışa sunulamadığı gösteren karikatür ise ilginçtir. ${ }^{74}$ Otuzlu yılların başından itibaren alınan birçok önleme karşı, maskelerin halka ulaştırılması konusunda mali nedenlerden dolayı bazı aksaklıkların yaşanmış olması muhtemeldir.

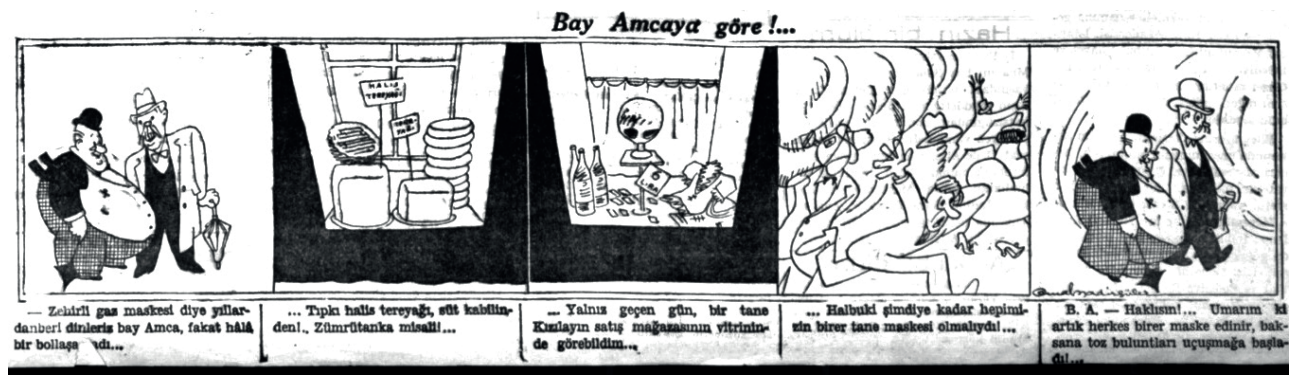

Şekil 11. Maskelerin Kızılay merkezlerinde bulunmadığını eleştiren karikatür (Akşam, 20 Nisan 1939, 3).

Mamak Gaz Maske Fabrikası, 14 Temmuz 1943 tarihinde kabul edilen Mamak Gaz Maske Fabrikasının Millî Müdafaa Vekâletine Devri Hakkında Kanun ile Millî Müdafaa Vekâleti’ne devredilmiştir. ${ }^{75}$

\section{Zehirli Gazdan Korunma Kurslarının Başlaması ve Anadolu Şehirlerindeki Kurs/Konferans Faaliyetleri}

1931 yılında Ankara'da askeri gaz kursu açılarak askeri personele zehirli gazdan korunma eğitimi verilmiş, 1932 yılında ise bu kursa Ankara dişında bulunan askeri personelin de katılması sağlanmıştır. Askerlere yönelik bu kurs faaliyetlerini, sivil vatandaşlara verilen kurslar izlemiştir. Öncelikli olarak Aralık 1934 tarihinde Ankara'da hekimlere yönelik zehirli gazdan korunma eğitimi verilmiştir. Bu kurs için gerekli olan malzemeler Fransa'dan ithal edilmiştir. ${ }^{76} \mathrm{Bu}$ eğitimlerdeki amaç her vilayette gazdan korunma konusunda eğitilmiş birer öğretmenin bulunmasını sağlamak olmuştur. Eğitici eğitimini almış olan bu hekimler, kendi şehirlerinde öncelikli olarak doktor, eczac1, kimyager, veteriner hekim, küçük sıhhat memuru gibi meslek mensuplarının eğitmesini ve kitleler halinde tüm yurttaşların da bu eğitimi almalarını sağlamaya çalışmışlardır. Hekimlere verilen eğitimden sonra kısım kısım farklı meslek mensupları da eğitilmiştir. Ağustos 1935 tarihinde yine Ankara' da 43 vilayetten gelen maarif müfettişleri ve öğretmenlere on beş gün sürecek bir kurs açılmış ve akabinde, şehirlerde kurs ve konferanslar verilmesi planlanmıştır. ${ }^{77}$ Ankara'daki kurstan sonra

74 Akşam, 20 Nisan 1939, 3.

75 T.C. Resmi Gazete, sayı 5460, 20 Temmuz 1943.

76 Çetin, “İkinci Dünya Savaşı'nda,” 19.

77 “Ankara'da Bir Zehirli Gaz Kursu Açıldı,” Cumhuriyet, 13 Ağustos 1935, 3. 
İstanbul'da da eğitici olarak görev yapacaklara da eğitim verilmiştir. Kimyager Necmettin Gülgeç, İstanbul'daki eğitimleri organize etmiş ve dersleri vermiştir. ${ }^{78}$ İstanbul' daki ilk kursa kırktan fazla Hükümet ve Belediye doktoru katılmış olup, kurs sekiz hafta boyunca devam etmiştir. ${ }^{79}$ Hekimlere yönelik verilen eğitimleri, Necmettin Gülgeç tarafından memurlara ve öğretmenlere verilen kurslar takip etmiştir.
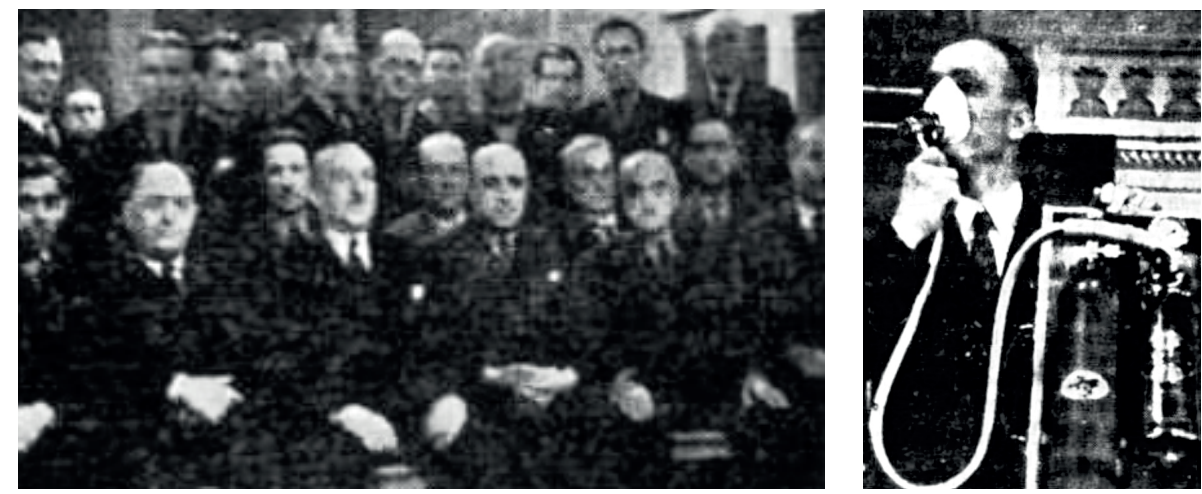

Şekil 12.1. 18 Şubat 1936'da İstanbul'da doktorlara verilen eğitici kursu (“Zehirli Gazlar İçin Dün Hükümet ve Belediye Doktorlarına Bir Konferans Verildi," Cumhuriyet, 19 Şubat 1936, 2).

Şekil 12.2. Kimyager Necmettin Gülgeç, İstanbul Üniversitesi konferans salonunda öğretmenlere yönelik kurs verirken (“Zehirli Gaz Kursu Bitti”, Cumhuriyet, 9 Haziran 1936, 4).

Ankara ve İstanbul'da eğitici olacaklara verilen kurslar devam ederken 1936 y1lında bir talimat yayınlamıştır. Beş maddeden oluşan Vilayetlerde Açılacak Hava ve Zehirli Gazdan Korunma Kursları Hakkında Talimat' da şehirlerde açılacak olan korunma kurslarının süreleri, müfredatları, anlatılacak konular, yapılacak olan tecrübe usulleri gibi birçok ayrıntıya yer verilmiştir.

Vilayet merkezlerinde açılacak kursları, 1934 yılında Ankara'da eğitim almış doktorlarla Genelkurmay Gaz Mektebi'nde yetişmiş tabip, kimyager ve zabitlerin vereceği ilan edilmiştir [Madde 2]. Kurslara katılması zorunlu olan meslek grupları ise doktor, kimyager, eczac1, diş hekimi, hemşire, küçük sıhhat memurları, dezenfensiyon memurları, hastabakıcı ve yardımcıları, baytar, ziraat memurları, mühendisler, jandarma, polis, itfaiye, zabıta ve gerekli belediye memurları olarak belirlenmiştir [Madde 2/a]. Yukarıda isimleri yazılan meslek mensupları, 15-20 gün devam eden bu kursa katılacak ve kendilerine, kurs sonunda yapılan sınav puanına göre sertifika verilecektir [Madde 2/a].

78 "Yakında Korunma Kursları Açılacak," Cumhuriyet, 9 İkinci Kanun [Ocak] 1936, 2.

79 "Doktorlar İçin Bir Kurs Aç1lyyor," Cumhuriyet, 18 Şubat 1936, 2; "Zehirli Gazlar İçin Dün Hükümet ve Belediye Doktorlarına Bir Konferans Verildi," Cumhuriyet, 19 Şubat 1936, 2. 
Bu talimatta hem eğiticiler ve hem de halk için iki farklı program açıklanmıştır: Eğiticiler için 15-20 gün süren "1 numaralı müfredat programı", halk için ise gece ve gündüz münasip zamanlarda sık sık verilecek konferanslardan oluşan "2 numaralı müfredat programı" belirlenmiştir [Müfredatlar için bkz. EK 2].

Kurs ve konferanslar için duruma göre halkevleri, mektepler, hastane konferans salonları, kimya, fizik, tabiiye laboratuvarlarının kullanılması planlamıştır [Madde 3/a]. Kurs ve konferansların yapılacağı mekânlarda münasip bir sığınak yapılması istenmiştir [Madde 3/b]. Kurs ve konferanslarda kullanılmak üzere gerekli kitapların listesi de [Madde 4] verilmiştir.

İstanbul'da Üsküdar, Adalar, Kadıköy, Fatih, Beykoz, Kartal, Bakırköy gibi ilçelerde kurslar açıldıktan sonra diğer semtlerde de gazdan korunma kursları açılmıştır. Beyoğlu'nda CHP binasında, Galata'da Rum İlk Mektebi’nde, Taksim'de Zapyon Lisesi’nde, Şişli’de Halkevi'nde, Kasımpaşa'da Dokuzuncu İlk Mekteb'de haftada 2-3 gün akşam 20.30'dan sonra kurslar verilmiştir. ${ }^{80}$ İstanbul'daki bu kurslara katılımı sağlamak daha doğrusu İstanbul'daki her aileden en az bir kişinin bu eğitimleri almasını sağlamak için evlere ilmühaberler gönderilmiş, grup grup aile üyeleri eğitime alınmıştır. ${ }^{81} 1938$ yılı ortasında 940.000 nüfusa sahip İstanbul'da zehirli gazdan korunma kursuna katılmış kişi sayısı ise 13.644 kadın ve 24.809 erkek olmak üzere toplam 38.453 'tür. ${ }^{82}$

İstanbul'daki kurslarda görev yapacak öğretmenlere 15 Temmuz 1936 tarihli Bakanlar Kurulu'nda isimsiz kadrolar çıkarılmıştır. ${ }^{83} 17$ Mart 1941 tarihinde çıkarılan kararnamede ise sadece Siyasal Bilgiler Fakültesi'ndeki öğrencilere zehirli gaz ve pasif korunma konuları üzerine konferans verecek uzmanlara her konferans için 8 lira ücret verilmesi kabul edilmiştir. ${ }^{84}$

Vilayetlerde açılan gazdan korunma kurslarına katılımın tam olarak sağlanmaması hatta bazı memurların kurs yoklamalarında eksik imzalarının bulunması üzerine 1937 yılında Sihhat ve İçtimaî Muavenet Vekâleti tarafından Başvekâlete bir resmi yazı yazılmış ve bu hususun takip edilmesi istenmiştir. ${ }^{85} \mathrm{Bu}$ yazı üzerine 8 Mart 1937 tarihinde bir tamim yayınlanarak, kurslara katılımın valiliklerce denetlenmesi sağlanmıştır. ${ }^{86}$ Memurların kursa katılımının zorunlu olduğu gazetelerde ilan edilmiştir. ${ }^{87}$ İstanbul'da faaliyete geçirilen

80 "Şehirde 45 Gaz Kursu Açılıyor," Cumhuriyet, 10 İkinci Teşrin [Kasım] 1937, 2; "Zehirli Gaz Kursları Faaliyete Geçti," Cumhuriyet, 5 Birinci Teşrin [Ekim] 1939, 2.

81 “Yüksek Gaz Kursu Açılıyor," Cumhuriyet, 18 İkinci Teşrin [Kasım] 1937, 2.

82 “1937-1938 Senesi Kış Devresinde İstanbul Zehirli Gaz Kurslarına Devam Edenlerin Listesi,” Zehirli Gazlar ve Bunlardan Korunma Mecmuası 1, 2 (1 Ağustos 1938): 19.

83 BCA, Başbakanlık Kararlar Daire Başkanlığg (B.KDB) 30.18.1.2/66.60.010, 15 Temmuz 1936.

84 BCA, B.KDB 30.18.1.2/94.21.14, 17 Mart 1941.

85 BCA, B.MGM 30.10/51.331.4, 20 Şubat 1937.

86 T.C. Resmi Gazete, say1 3548, 8 Mart 1937.

87 “Zehirli Gazler Kursularına Devam Edecek Memurlar,” Cumhuriyet, 8 Mart 1937, 2. 
kurslara memurların dışında da her evden iki kişinin katılmasının zorunlu olduğu ve kursa katılmayanlara 5 liradan 25 liraya kadar para cezası verileceği duyuruluştur. ${ }^{88}$

1939 yılında Genelkurmay Başkanı Fevzi Çakmak Paşa tarafından Başvekâlete gönderilen yazıda gaz mektebi inşası bütçesinin ve yurdun her tarafından açılmaya çalışılan gazdan korunma kurslarının öğretmen ve malzeme tedarikinin yeterli olamadığı bu ihtiyacın karşılanması adına her vekâletten belirlenmiş bir bütçenin Milli Müdafaa Vekâleti'ne aktarılması istenmiştir. ${ }^{89}$ Konu Maliye Vekâleti'ne yazılı olarak iletilmiş ve Vekâlet'ten gelen yazılı cevap 1939 yılı bütçesi yapılmış olduğundan bu talebin karşılanamayacağı yönünde olmuştur. Benzer bir talep ise 1939 yılında Adliye Vekili Fethi Okyar'dan gelmiştir. Başvekâlete yazılan yazıda ${ }^{90}$ adliyelerde bulunması zorunlu olan sı̆̆ınak ve gazdan korunma malzemelerinin tedariki için bütçede ayrı bir tahsisatın olmaması nedeniyle ayrı bir tahsisat istenmiştir. Maliye Vekâleti'nden verilen cevapta da bütçeye başlangıçta bu tahsisatın konulduğu ve fakat İcra Vekilleri Heyeti tarafından bütçeden çıkartılması nedeniyle tekraren bütçeye böyle bir tahsisatın konulamayacağı yönündedir. ${ }^{91}$

Türkiye Eczacılar Cemiyeti Merkez Heyeti kendi bünyesinde sadece eczacilara yönelik olacak zehirli gazlardan korunma kursu açmak için faaliyete geçmiştir.92 1937 yılında sadece eczacıların katılığı hususi bir kurs açılmıştır. ${ }^{93} \mathrm{Bu}$ olay, resmi girişimlerin yanında sivil toplum girişimlerine örnek gösterilebilir.

\section{Anadolu Şehirlerindeki Kurs/Konferans Faaliyetleri}

İstanbul ve Ankara'da yapılan kurs faaliyetlerinin benzerleri de farklı şehirlerde yapılmıştır. Bu kursları, 1934 yılında Ankara'da eğitim alan doktorlar ile ilk kursları başarılı notla bitirenler vermişlerdir. 1936 yılında Ordu'da doktor, eczacı, diş hekimi, sağlık memuru ve öğretmenler için iki ay süren bir kurs yapılmış ve kursun sonunda talimatname gereğince sertifika verilmiştir. ${ }^{94}$ Yine 1936 y1lında Kastamonu'da, Kastamonu Lisesinin konferans salonunda on gün boyunca devam eden zehirli gazdan korunma kursları verilmiştir. ${ }^{95}$

Sivas’taki kurslar üç devre halinde yapılmış ve kursları Kuduz Tedavi Müessesesi Direktörü ve Numune Hastanesi Dâhiliye Mütehassısı Dr. Celal Yarkinöz vermiştir. Birinci devre kurs haftada üç gün olarak ikişer saatlik dersler halinde yapılmış ve otuz kişi katılmıştır. İkinci devre kursa ise seksen iki kişi katılmıştır. Kurslara doktorlar, hemşireler,

88 “Zehirli Gaz Kursu: Kursa Devam Etmeyenler Para Cezası Alacak,” Cumhuriyet, 24 Mart 1937, 2.

89 BCA, B.MGM 30.10/51.332.9, 12 Temmuz 1939.

90 BCA, B.MGM 30.10/51.332.17.4, 8 Kasim 1939.

91 BCA, B.MGM 30.10/51.332.17.2, 8 Kasim 1939; BCA, B. MGM 30.10/51.332.17.3, 8 Kasim 1939.

92 “Meslek Haberleri," Farmakoloğ 7, 3-4 (1937): 67.

93 “1937-1938 Yılı Birliğin Mesai Raporudur,” Farmakoloğ 8, 4-6 (1938): 51.

94 “Ordu'da Zehirli Gaz Kursu,” Cumhuriyet, 24 Temmuz 1936, 2.

95 “Kastamonu'da Zehirli Gaz Kursu,” Cumhuriyet, 10 Ağustos 1936, 2. 
sıhhat memurları; belediye, itfaiye ve zabıta memurları, ziraatçı, baytar ve öğretmenler katılmıştır. Sivil halka ise camilerde, sinema salonlarında ve hükümet konağında konferanslar verilmiştir. ${ }^{96}$

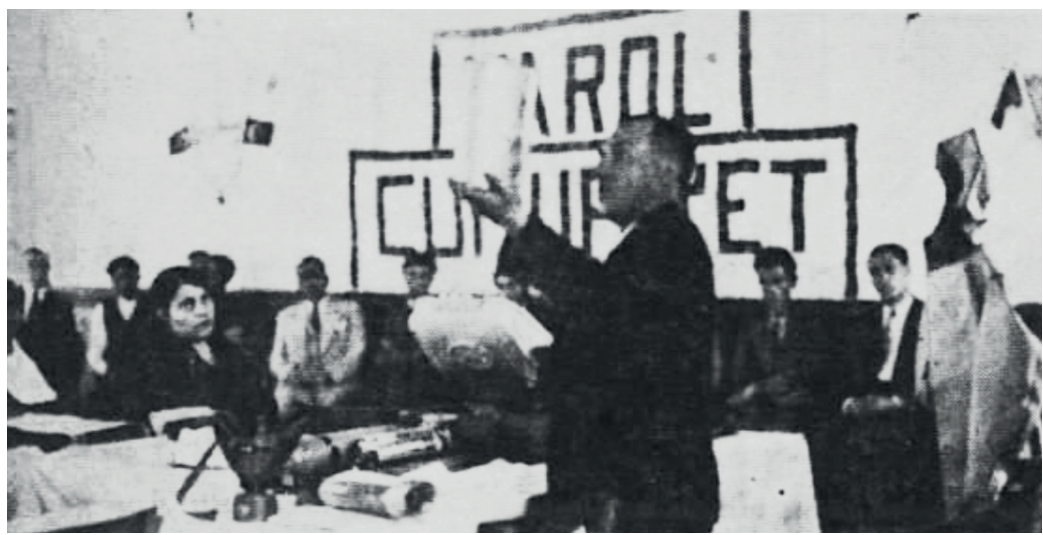

Şekil 13.1. Ordu'daki gaz kursu, 1936

(“Ordu'da Zehirli Gaz Kursu,” Cumhuriyet, 24 Temmuz 1936, 2).

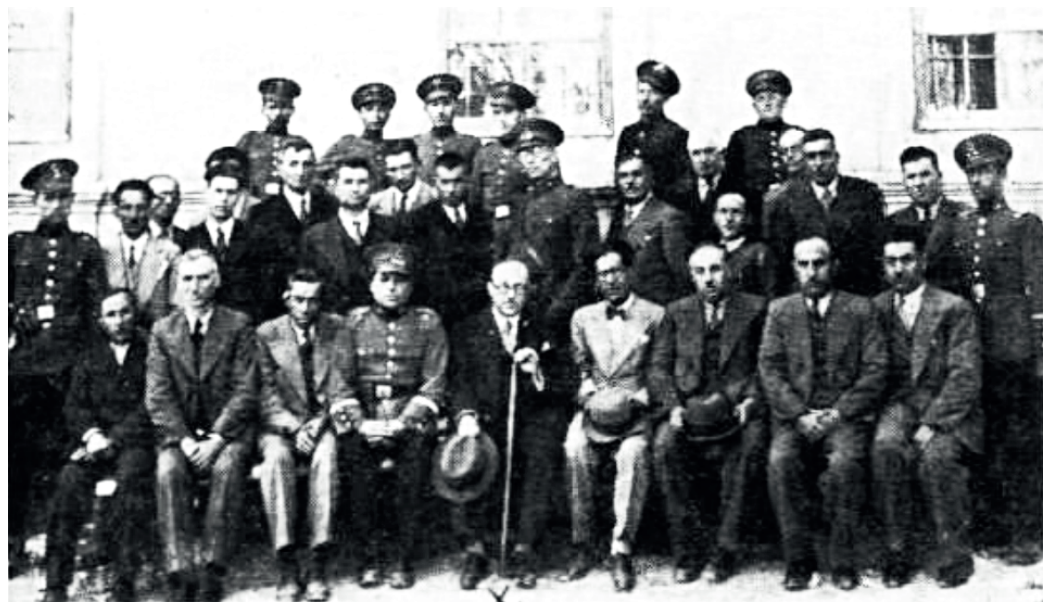

Şekil 13.2. Sivas'taki gaz kursu, 1936

(“Sivas’ta Zehirli Gaz Kursu,” Cumhuriyet, 20 İkinci Teşrin [Kasım] 1936, 2).

1937 yılında Trabzon'da on iki gün boyunca iki devre halinde devam eden zehirli gazdan korunma kursları Ordu Memleket Hastanesi Dahiliye Mütehassısı Zeki Mesud Bey tarafından verilmiştir. Kurslara itfaiye, zabıta, belediye memurları; doktorlar, polis ve askerler katılmıştır. Kursa toplam 160 kişi katılmış olup bunlardan 38'i halka konferans verebilecek düzeyde eğitilmiştir. Zeki Mesud Bey Trabzon'da ayrıca halka yönelik üç konferans da vermiştir.97

96 “Sivas’ta Zehirli Gaz Kursu," Cumhuriyet, 20 İkinci Teşrin [Kasım] 1936, 2.

97 “Trabzon'da Zehirli Gaz Kursları Açıldı,” Cumhuriyet, 25 Nisan 1937, 2. 
Bursa, Mustafakemalpaşa'da Maarif Müfettişi İhsan Bey tarafından beş gün süren kurs verilmiştir. Kursa, kazadaki tüm memur ve öğretmenler katılmıştır. ${ }^{98}$

Niğde'de memurlar için gaz kursu açılmıştır. Şehirdeki tüm memurlar kursa iştirak etmişlerdir. ${ }^{99}$

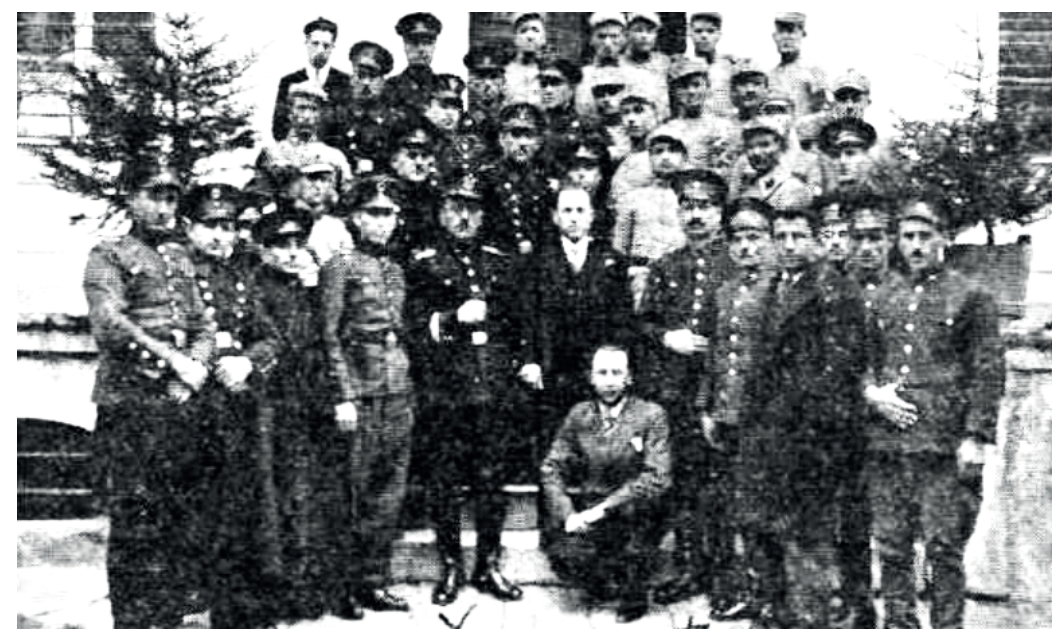

Şekil 13.3. Trabzon'daki gaz kursu, 1937

(“Trabzon'da Zehirli Gaz Kursları Açıldı,” Cumhuriyet, 25 Nisan 1937, 2).

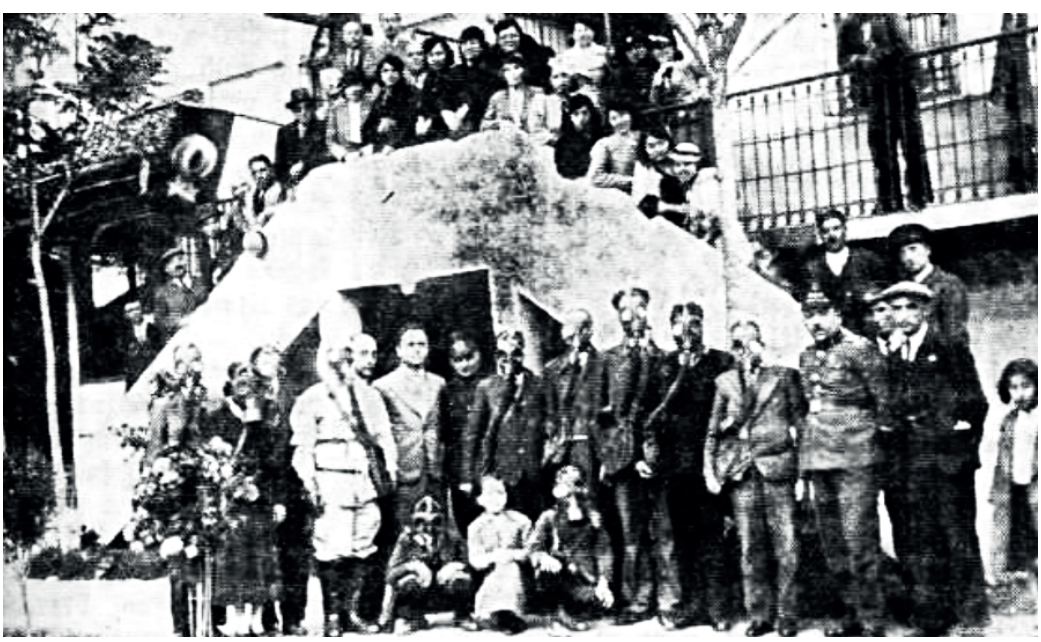

Şekil 13.4. Bursa, Mustafakemalpaşa' daki gaz kursu, 1937

(“Mustafakemalpaşa Kazasında Açılan Gaz Kursu,” Cumhuriyet, 30 Mayıs 1937, 2).

98 "Mustafakemalpaşa Kazasında Açılan Gaz Kursu," Cumhuriyet, 30 Mayıs 1937, 2.

99 "Niğde Memurları İçin Zehirli Gaz Kursu Açıldı," Cumhuriyet, 7 Haziran 1937, 7. 


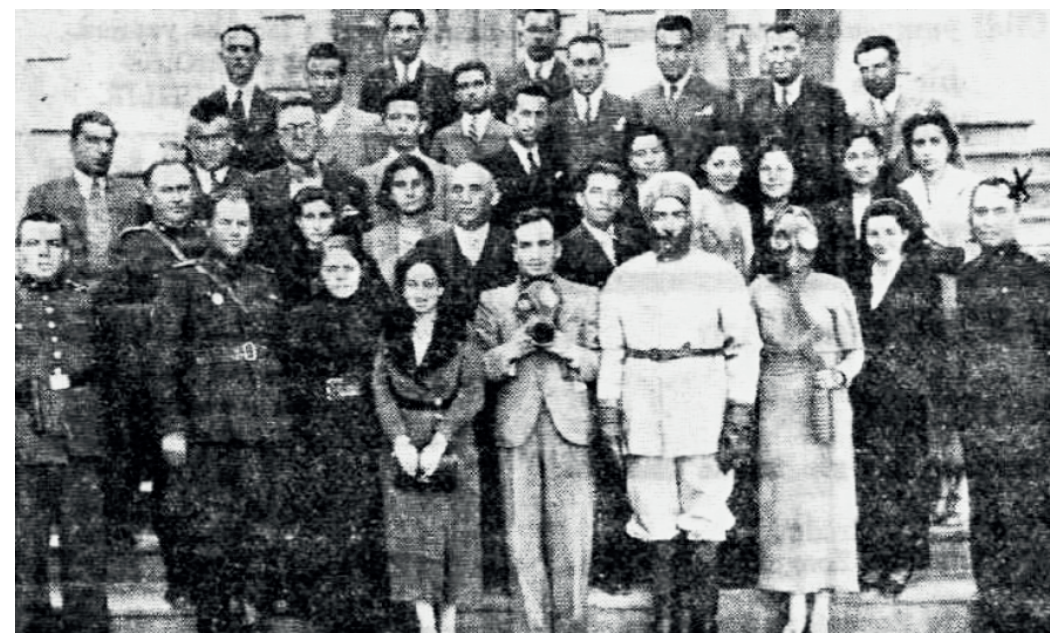

Şekil 13.5. Niğgde'deki gaz kursu, 1937

("Niğde Memurları İçin Zehirli Gaz Kursu Açıldı," Cumhuriyet, 7 Haziran 1937, 7).

1938 yılında, Edirne'de yoğun katılımlı bir gaz konferansı gerçekleşmiştir. Konferansı Gaz Genel Komutanı Hüsnü Rıza Ünsal, Edirne Halkevi binasında vermiştir. Konferansa şehir protokolü ve sivil halk katılmıştır. Bu konferanstan sonra Kimyager Yüzbaşı Arif Tekman zehirli gazlar hakkında bir konferans vermiş, hava tehlikesi konulu bir film sinemada izlenmiş ve sinema bahçesinde sis denemeleri yapılarak maske takma usulleri gösterilmiştir. ${ }^{100}$

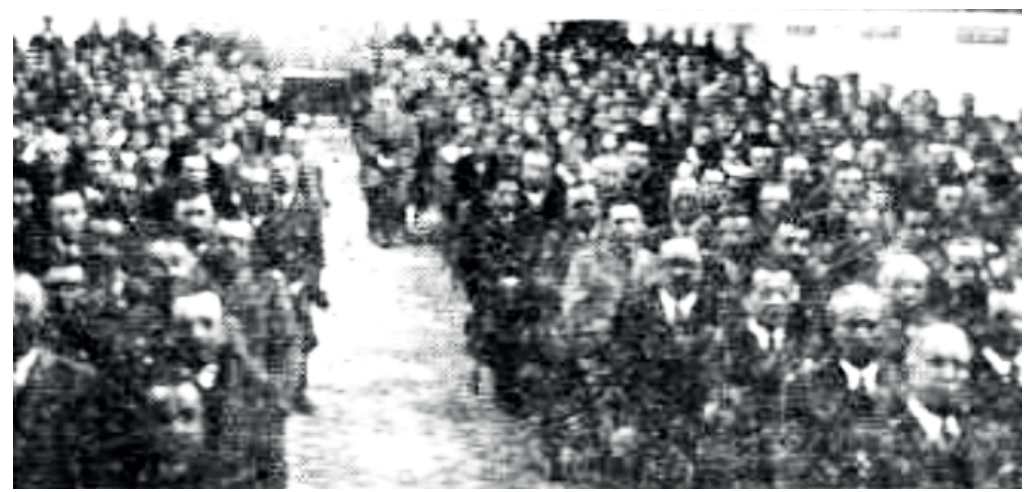

Şekil 13.6. Edirne'deki gaz konferans1 ve kursu, 1938

("Edirne'de Gaz Konferans1," Cumhuriyet, 10 Nisan 1938, 6).

Bursa, İnegöl'de halkevi binasında zehirli gaz kursları açılmış ve konferans şeklinde yapılmıştır. Kursa iki yüzden fazla vatandaş katılmıştır. ${ }^{101}$ Bursa merkezde CHP binasında 
on beş gün süren bir kurs açılmıştır. Kursun öğretmenliklerini Asteğmen Recai Bey ile Bakteriyolog Lütfi Bey yapmış, kursa doktor ve askerler katılmıştır. Her gün saat 14.00'den 17.00’ye kadar devam eden kursa katılanlardan imtihanları başarıyla geçenler şehrin farklı noktalarından açılacak kurslarda öğretmenlik yapmışlardır. ${ }^{102}$ Bu kurstan başarıyla geçenler tarafından şehir merkezinde dört ayrı kurs daha açılmıştır. ${ }^{103} 1939$ yılında dört ayrı kurs açılmış ve kursları Dr. Lütfi Karlova, Dr. Hüdai Rona, Teğmen Recai Bey ve orta mektep müdür muavini Ahmet Muhtar Bey idare etmiştir. ${ }^{104}$

1939 yılında Kırklareli Halkevi'nde gaz kursu açılmıştır. Kursu 68. Alay subayı İhsan Akacun idare etmiş ve kurs on beş gün boyunca devam etmiştir. Kursa tüm memurlar katılmıştır. ${ }^{105}$ Manisa Halkevi’nde de 1939 yılında gaz kursu açılmıştır. ${ }^{106}$

Kurslarda gazların tanınması, kullanılması, saklanma gibi yöntemlerin yanında gazdan etkilenmiş bireylere müdahale etme ve tedavi metotları üzerine bilgiler verilmiştir. $\mathrm{Bu}$ konuda özel olarak yazılmış kitaplar ${ }^{107}$ olmakla birlikte kurslar için hazırlanmış kitaplarda da bölümler halinde tedavi metotlarından bahsedilmiştir. Açılan gazdan korunma kursları tamamlayan vatandaşlara diploma verilmiştir.

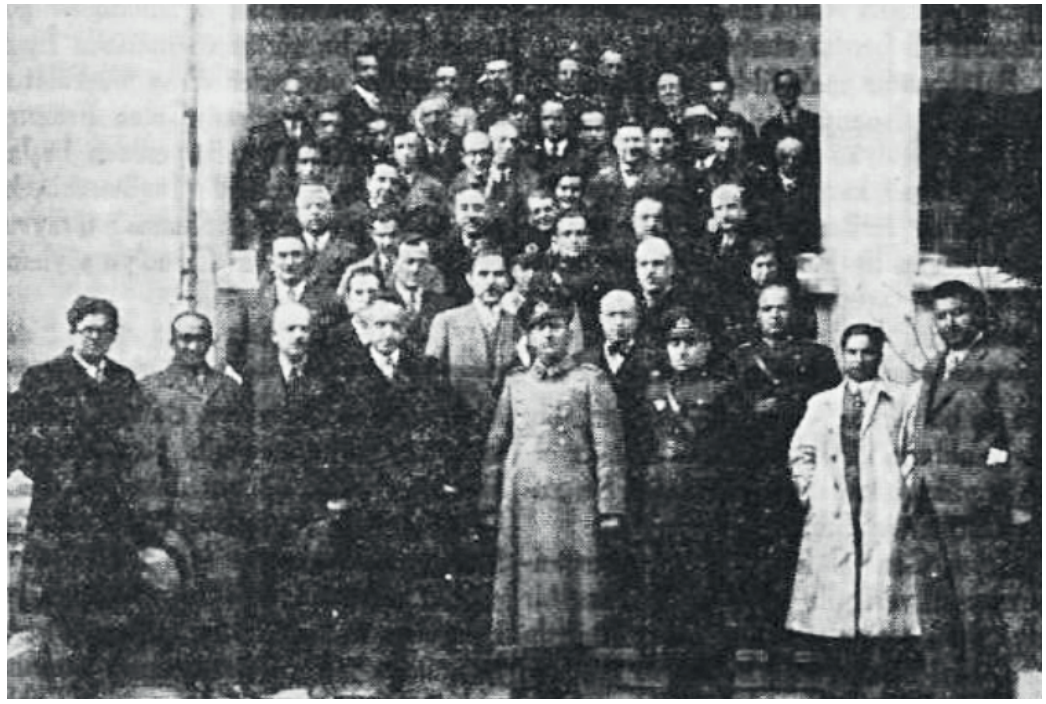

Şekil 13.7. Bursa merkezdeki gaz kursu, 1938

("Bursa'da Zehirli Gaz Kursu," Cumhuriyet, 14 Nisan 1938, 2).

102 "Bursa'da Zehirli Gaz Kursu," Cumhuriyet, 14 Nisan 1938, 2.

103 “Bursa'daki Zehirli Gaz Kursları," Cumhuriyet, 20 Mayıs 1938, 2.

104 “Bursa'da Zehirli Gaz Kursları,” Cumhuriyet, 19 Nisan 1939, 2.

105 “Kurklareli’nde Zehirli Gaz Kursu," Cumhuriyet, 17 Mart 1939, 7.

106 “Manisa Halkevinde Yeni Bir Kurs Açıldı,” Akşam, 21 Nisan 1939, 7.

107 Akil Muhtar Özden, Hava-Kimya Muharebelerine Karşı İlkyardım ve Tedavi (İstanbul: Ahmed İhsan Basımevi, 1939). 


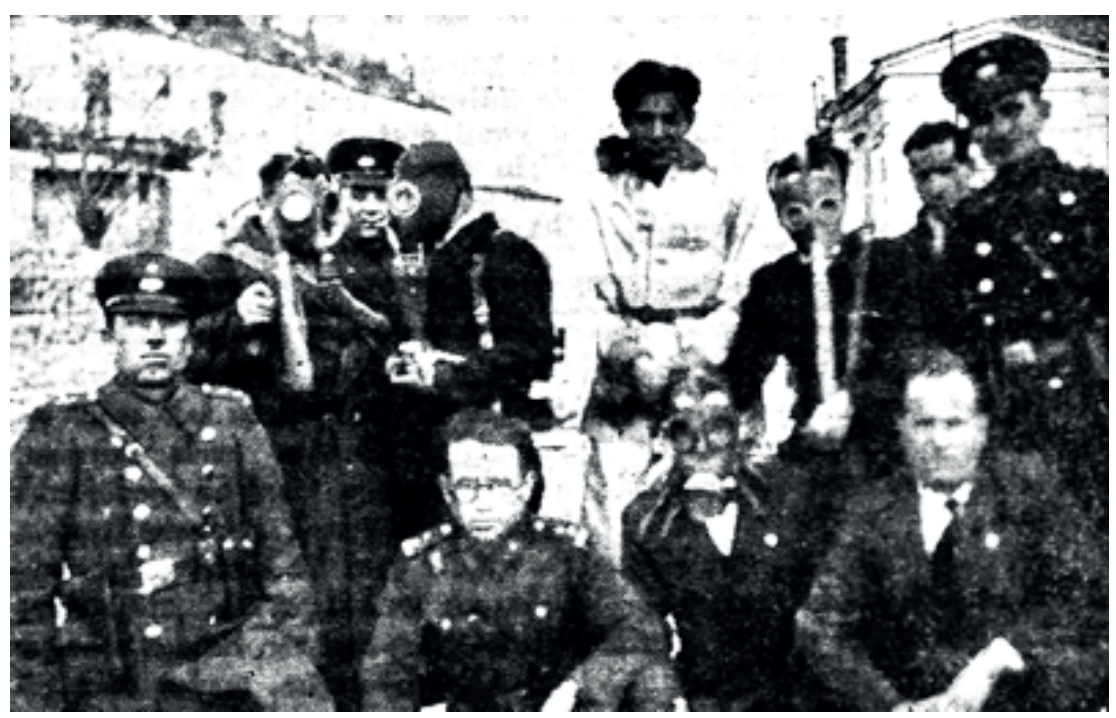

Şekil 13.8. Kırklareli'ndeki gaz kursu, 1939

(“Kurklareli’nde Zehirli Gaz Kursu," Cumhuriyet, 17 Mart 1939, 7).

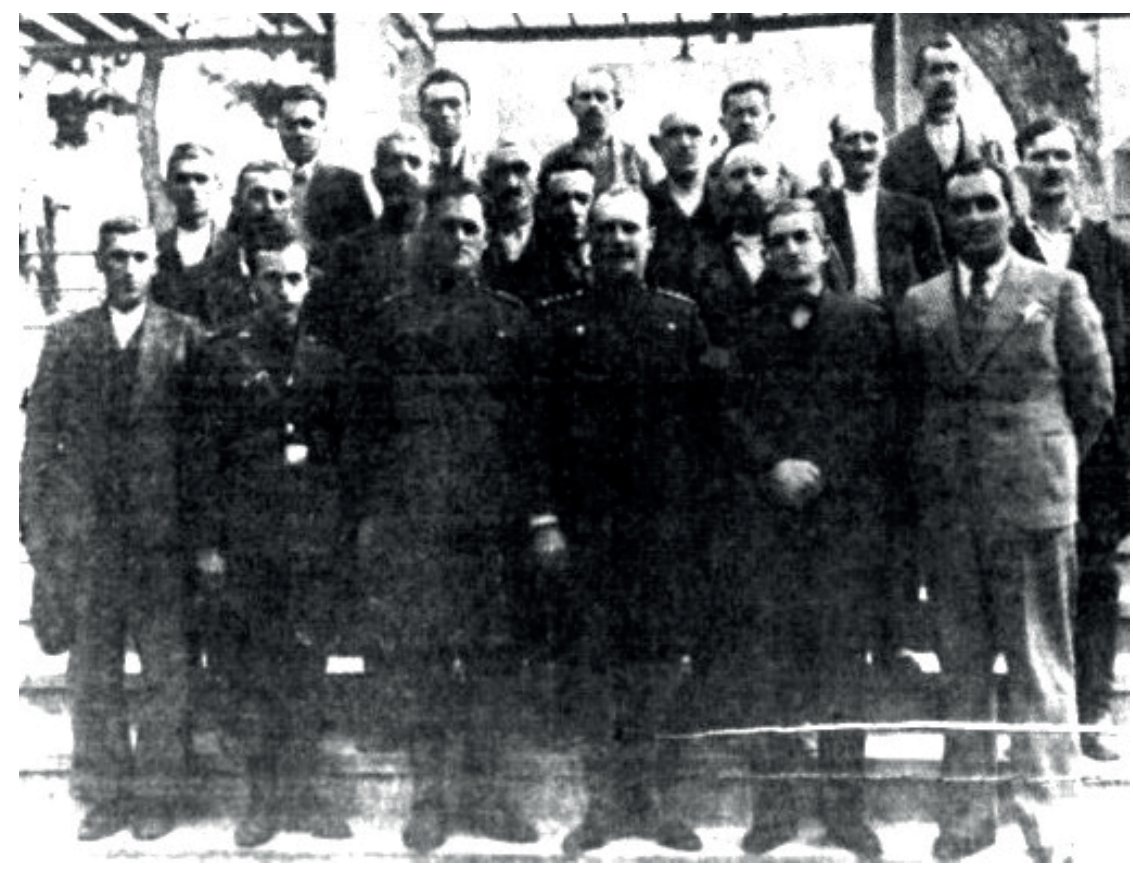

Şekil 13.9. Manisa'daki gaz kursu, 1939.

("Manisa Halkevinde Yeni Bir Kurs Açıldı," Akşam, 21 Nisan 1939, 7.) 


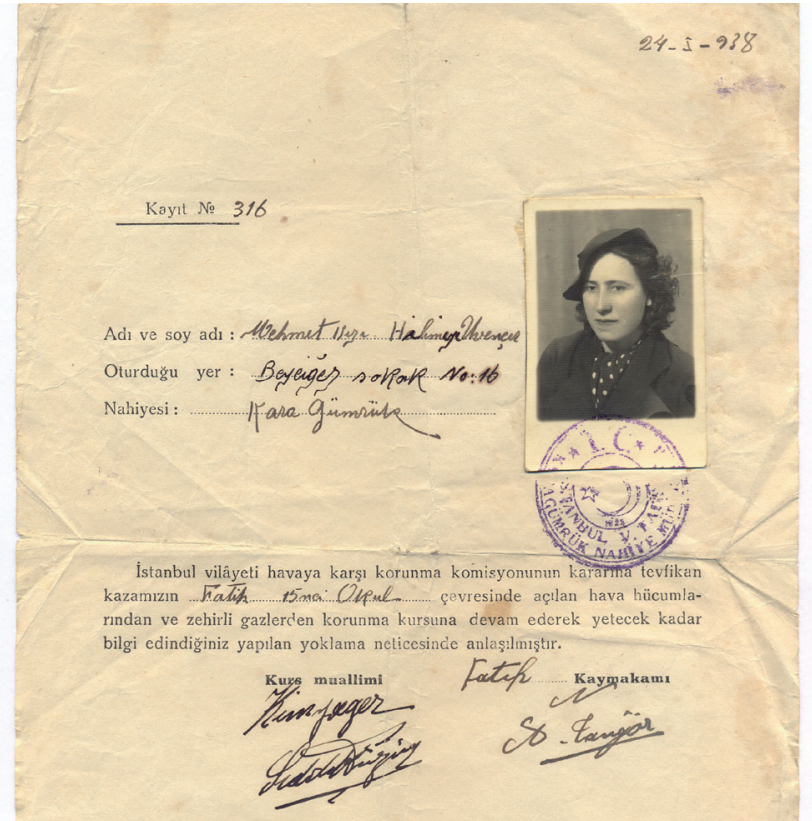

Şekil 14.1. 1938 yılında Fatih Kaymakamlığı'ndan verilen diploma (Emre Dölen Koleksiyonu).

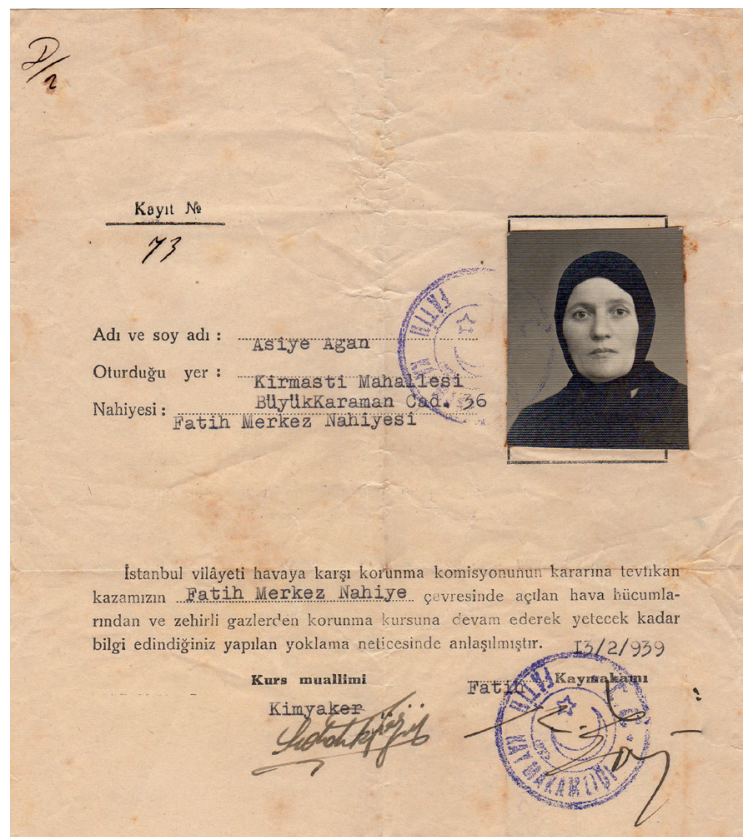

Şekil 14.2. 1939 yılında Fatih Kaymakamlı̆̆ı'ndan verilen diploma (Eyüp Talha Kocacık Koleksiyonu). 


\section{Veteriner Hekimlere Yönelik Kurslar}

8 Nisan 1939 tarihinden yürürlüğe giren Hava Taarruzlarına Karşı Pasif Korunma Nizamnamesi'nin Veteriner Hizmetleri bölümünde pasif korunmaya tabi olan şehir ve kasabalarda hava taarruzlarına karşı hayvanları korumak ve hayvan mevcuduna göre mahalli korunma komisyonunca veteriner hizmeti teşekküllerini hayata geçirmek mecburiyeti getirilmiştir. Mahalli veteriner müdürü, teşekküllerin oluşturulması için pasif korunma veteriner amiri olarak kaydedilmiştir [Madde 117]. Vilayet veteriner müdürleri tarafindan veteriner hekimler Ziraat Vekâleti'nce açılacak kurslara yerleştirilecek ve yılda otuz saatten oluşacak bu kurslarda eğitim almış veteriner hekimler de vilayet merkezleri ile kazalarda kurs açarak veteriner hekimleri eğiteceklerdir [Madde 119]. Kurslara; askerlikle ilgisi olmayan altmış yaşına kadar olan veteriner hekimler ile emekli nalbantbaşılar, veteriner ve nalbant gediklisi olanlar, haralarda ve çiftliklerde hayvan bakımında bulunmuş olanlar, nalbantlar ve hayvan bakımına alışkın olanlar da alınabilecektir [Madde 120].

Nizamnamede gazdan zarar görmüş hayvanları tedavi etmek için açılacak hayvan hastanelerinin yerleri ve özellikleri de belirtilmiştir [Madde 121, 122, 123]. Bu nizamnameden hareketle 18 Nisan 1939 tarihinde Hava Hücumlarına Karşı Hayvanların ve Hayvanlardan Husule Gelen Yiyecek Maddelerinin Korunmasına Dair Talimatname yayınlanmıştır. Talimatnamede gaz saldırısı sonucunda zarar görmüş hayvanların nasıl tedavi edileceği, ne şekilde korunacağı, mezbahalarda kesim yöntemleri, hizmette bulunan hayvanların korunma ve tedavi yöntemleri gibi birçok konu açıkça belirtilmiştir. ${ }^{108}$

Hava Taarruzlarına Karşı Pasif Korunma Nizamnamesi 'nin 119. maddesi uyarınca Ziraat Vekâleti "Havaya Karşı Veteriner Pasif Korunma Kursları" açmıştır. Ankara Yüksek Ziraat Enstitüsü'nde 1 Nisan 1940 tarihinde açılan kursa 90 lira ücretle öğretmen olarak Veteriner Yarbay Sadettin Tektaş atanmıştır. ${ }^{109}$ On sekiz gün süren kursa, vilayet veteriner müdürleri ile Veteriner Fakültesi son sınıf öğrencileri katılmıştır. Tektaş, kursta verdiği ders notlarını bir araya getirmiş, bunlar ders kitabı olarak Yüksek Ziraat Enstitüsü tarafından basılmıştır. Kitapta gazlar hakkında genel bilgiler, gazların sınıflandırılması, gazların kullanım usulleri, gazlara karşı korunma ve temizlenme, hayvan kaynaklı yiyeceklerin ve suların korunma ve temizliği gibi birçok hususta bilgiler bulunmaktadır.

108 T.C. Resmi Gazete, say1 4186, 18 Nisan 1939.

109 BCA, B.KDB 30.18.1.2/90.13.1, 3 Şubat 1940. Sadettin Tektaş, 1919 yılında askeri veteriner hekim olarak mezun olmuştur. Bkz. Muzaffer Bekman, Veteriner Tarihi (Ankara: Ankara Basım ve Ciltevi, 1940), 262. Tektaş, 30.8.1953 tarihinde generalliğe terfi etmiştir. Bkz. Ferruh Dinçer, "Türkiye'de Askeri Veteriner Hekimlik Tarihi Üzerinde Araştırmalar-II," Ankara Üniversitesi Veteriner Fakültesi Dergisi 27, 1-2 (1980): 265 . 


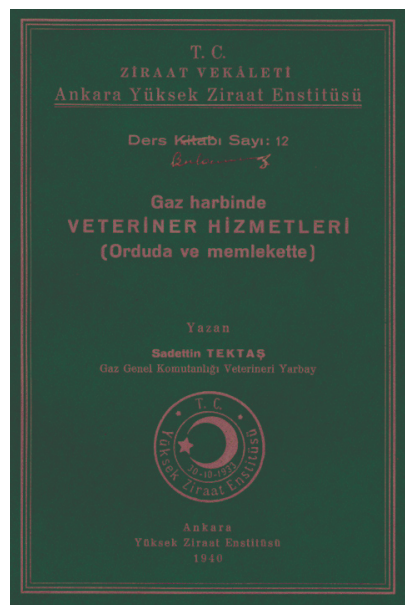

Şekil 15. Veteriner Yarbay Sadettin Tektaş'ın hazırladığı kitabın (1940) kapağı (Eyüp Talha Kocacık Koleksiyonu).

\section{Zehirli Gazlar ve Bunlardan Korunma Mecmuası (1938)}

Eczacı Kimyager Hikmet Konuralp ile Eczacı Kimyager Abidin Özger tarafından 1 Temmuz 1938 tarihinde yayınlanmaya başlamış olan dergi, özellikle sivil vatandaşlara zehirli gazlar hakkından genel bilgiler vermeyi amaçlamıştır. Merkezi İstanbul'da olan dergi on kuruşa satılmaktadır. Dergide, hava taaruzu tehlikesi, maske kullanımı, yeni keşfedilen zehirli gazlar ve korunma yöntemleri, gaz üretimi gibi konularda yazılar yayınlanmıştır. Dergide ayrıca gaz kurslarında üstün başarı gösteren öğretmenlerin isimleri, kurslara katılan erkek-kadın sayı ve oranları da yayınlamıştır.
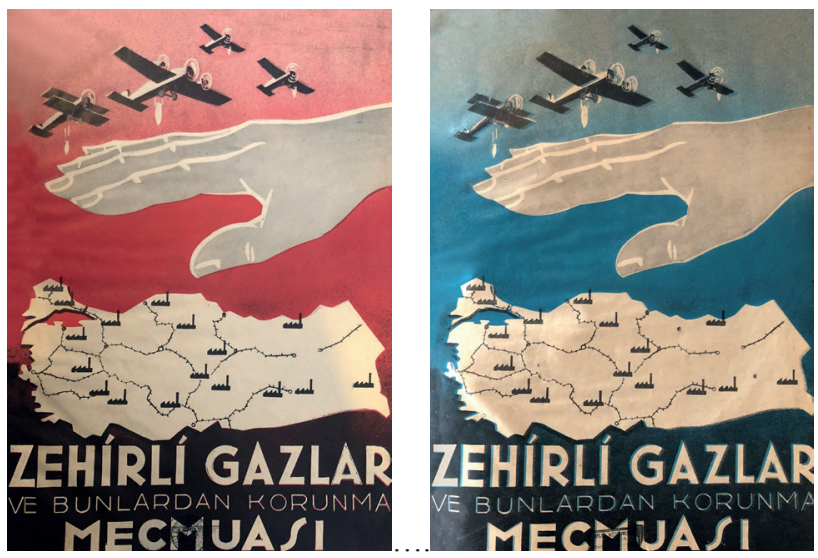

Şekil 16.1. (solda) Zehirli Gazlar ve Bunlardan Korunma Mecmuası Sayı 1, 1 (1 Temmuz 1938).

(BCA Siyasi Partiler Cumhuriyet Halk Partisi (SP. CHP) 490.1/1363.523.3, 12 Ağustos 1938).

Şekil 16.2. (sağda) Zehirli Gazlar ve Bunlardan Korunma Mecmuası Sayı 1, 2 (1 Ağustos 1938) (Milli Kütüphane Koleksiyonu No. 1957. SB. 172). 


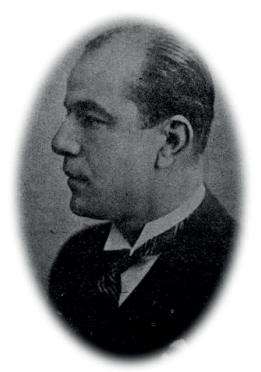

Şekil 16.3. Eczac1 Kimyager Hikmet Konuralp

(Zehirli Gazlar ve Bunlardan Korunma Mecmuası 1, 1 (1 Temmuz 1938): 9.)

\section{Gönüllü Hastabakıcılık Kursları ve Gazdan Korunma Dersleri}

İkinci Dünya Savaşı esnasında zehirli gazdan korunma kursları açıldığı gibi bir başka hassasiyetin ürünü olan bir kurs daha hayata geçirilmiştir. Gönüllü hastabakıcılık ve hemşirelik kursu, bir savaş durumunda ihtiyacı karşılamak üzere açılmıştır. Kızılay bünyesinde kurslar açılmış, gazetelere hastabakıcılık kursuna başvuru ilanları yayınlamıştır. ${ }^{110}$

İstanbul'da Gümüşsuyu Askeri Hastanesi'nde gönüllü hastabakıcıllk ve hemşirelik kursu açılmış ve iki buçuk aylık dönemler halinde hemşire yetiştirmiştir. Bu kursların dördüncü dönemi de Temmuz 1941 'de tamamlanmış olup, kurslarda genel sağlık eğitiminin yanında zehirli gazdan korunma ve tedavi yöntemleri üzerine eğitim verilmiştir. ${ }^{111}$

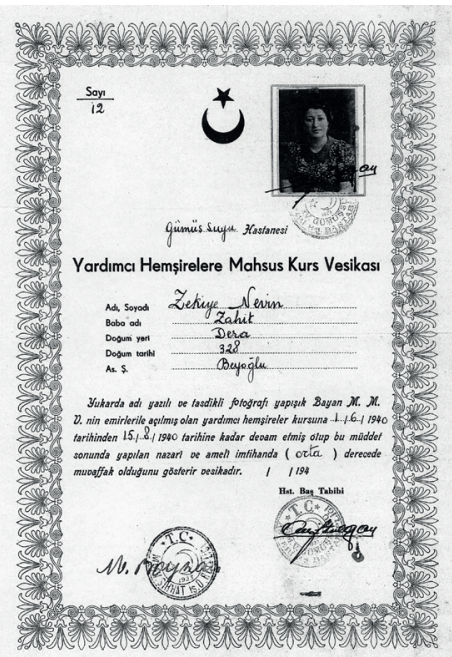

Şekil 17.1. Gümüşsuyu Hastanesi'nde gönüllü hemşirelik kursuna katılan Zekiye Nevin Zahit'e verilen 'Kurs Vesikası' (Emre Dölen Koleksiyonu.)

110 Gülhan Seyhun, Tıp Tarihimizde Askerî Sağlık Hizmetleri II. Dünya Savaşı Dönemi (İstanbul: Altınbaş Üniversitesi, 2018), 146-152.

111 “Gümüşsuyu’ndaki Kurs Bitti,” Cumhuriyet, 23 Temmuz 1941, 5. 


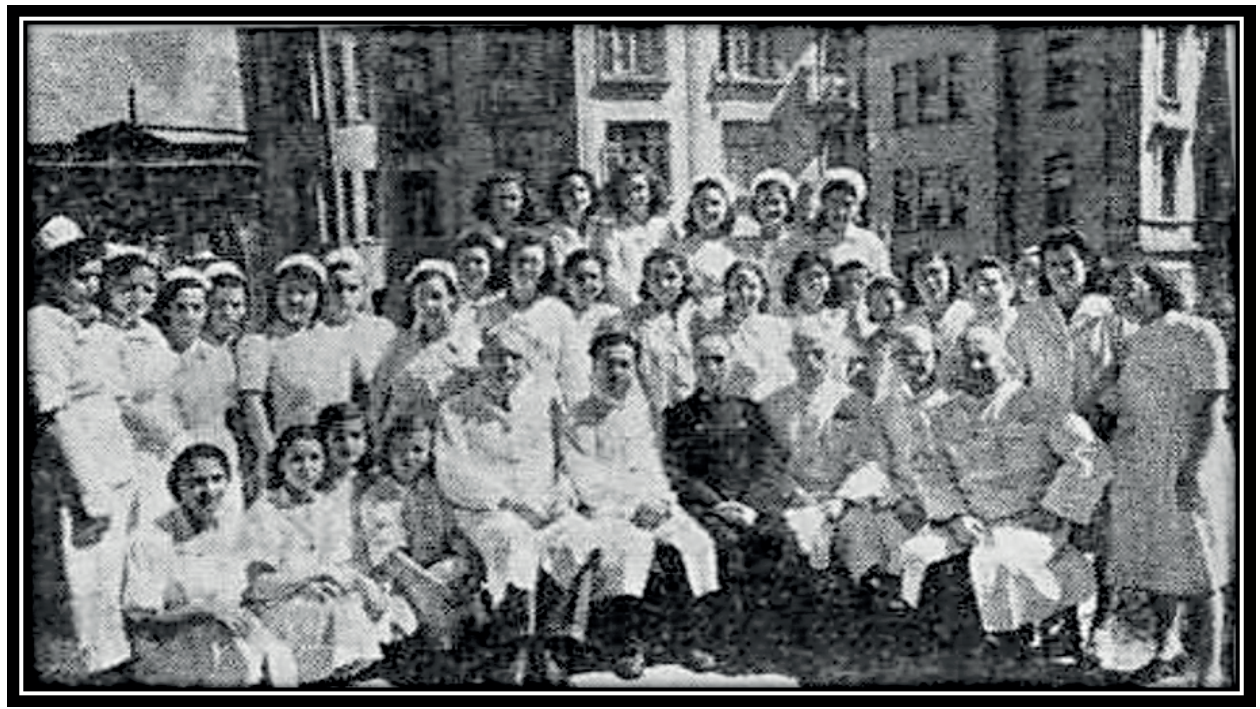

Şekil 17.2. Gümüşsuyu Hastanesi’nde açılan gönüllü hastabakıcılık kursu (“Gümüşsuyu'ndaki Kurs Bitti,” Cumhuriyet, 23 Temmuz 1941, 5).

İstanbul'daki kurstan sonra Ankara' da 1 Mart 1944 tarihinde gönüllü hastabakıcılık kursu açılmıştır. Kursa 1 numaralı kaydı Mevhibe İnönü Hanım yaptırmış ve diploma almıştır. Ankara'daki ilk kursa 150 bayan kayıt yaptırmış ve diploma almıştır. ${ }^{112}$ Ankara'daki bu kurslarda, ders arasında da zehirli gazdan korunma ve ilkyardım eğitimi verilmiştir.

\section{Sonuç ve Değerlendirme}

Yeni kurulan Türkiye Cumhuriyeti, Birinci Dünya Savaşı'nda edilen tecrübeler neticesinde herhangi bir savaşta olası kimyasal saldırılara karşı korunmada halkı eğitme ve koruma konusunda oldukça erken tarihte düzenlemeler yapmaya başlamıştır. Öncelikle askeri ve kamu personelini zehirli gaz konusunda bilinçlendirmekle başlayan süreç, Anadolu şehirlerinde sivil halkın eğitilmesine kadar sürdürülmüştür.

1930'lu yılların başından itibaren öncelikli olarak konferanslar şeklinde gazdan korunma bilgileri öğretilirken daha sonraki dönemlerde gazdan korunma kursları adı altında hemen hemen tüm yurtta, halka yönelik kurslar açılmıştır. Kurslarda maske kullanmak, gazdan korunmak ve gaz maruziyetine karşı tedavi yöntemleri, sığınak yapmak ve sığınağı kullanmak gibi birçok konuda farkındalık yaratılmaya çalışılmıştır.

İlk etapta, halka kurs açabilmek ve halkı bilinçlendirmek maksadiyla hekimlere, eczacılara ve öğretmenlere yönelik eğitim verilmiş ve ardından, Anadolu'daki şehir ve kaza

112 Ali Korur, Gönüllü Hastabakıcılık, 3. 
merkezlerinde gazdan korunma kursları açılmıştır. Bu kurslara devam mecburiyeti getirilmiş ve kurs sonunda verilen diplomalarla eğitimden geçirilen vatandaşların kaydı tutulmuştur.

Toplumun tüm tabakalarını ilgilendiren gaz saldırısı konusunda veteriner hekim ve hemşirelere özel kurslar açılmış ve toplum sağlığı korunmaya çalışılmıştır. Halka pasif korunma yöntemlerinin öğretilmesinin yanı sıra bir maske fabrikası açılmış, Hava Hücumlarından Korunma Cemiyeti faaliyete başlamış, zehirli gazlar konuları üzerine dergi ve kitaplar yayınlanmıştır. Zehirli gazdan korunma yöntemleri ile ilgili bazı kitapların kapakları [EK 4’te] verilmiştir.

\section{Zehirli gazlar ve kurslar ile ilgili olarak}

Türkiye'de yapılan başlıca faaliyet ve yasal düzenlemelerin kronolojisi (1931-1940)

\begin{tabular}{|c|c|}
\hline Olaylar & Tarih \\
\hline Halk İçin Havaya Karşı Korunma Talimatı & 1931 \\
\hline Askeri Gaz Kursu, Ankara & 1931 \\
\hline Darülfünun'da Ömer Şevket Öncel tarafından verilen konferanslar & 1933 \\
\hline Mazlum Boysan tarafindan verilen konferansalar & 1933 \\
\hline Hava Hücumlarından Korunma Cemiyeti & 1933 \\
\hline Hekimlere yönelik eğitimler & 1934 \\
\hline $\begin{array}{l}\text { Zehirli Gazlarla Bunları Kullanmaya Mahsus Vasıtaların Memlekete Sokulmasının ve Memlekette } \\
\text { Yaptırılmasının Men'i Hakkında Kanun }\end{array}$ & 1934 \\
\hline Nuri Kutkan tarafindan verilen konferanslar & 1935 \\
\hline Mamak Gaz Maske Fabrikası & 1935 \\
\hline Kimya Harbinden Korunmaya Mahsus Malzeme Hakkında Kanun & 1935 \\
\hline Hava Taarruzlarına Karşı Korunmada Yurt Sıhhat İşleri Talimatı & 1935 \\
\hline Vilayetlerde Açılacak Hava ve Zehirli Gazdan Korunma Kursları Hakkında Talimat & 1936 \\
\hline Hava Müdafaa Genel Komutanlığı Teşkili ve Vazifesi Hakkında Kanun & 1937 \\
\hline Hava Taarruzlarına Karşı Korunma Kanunu & 1938 \\
\hline Veteriner Hekimlere yönelik kurslar & 1938 \\
\hline Zehirli Gazlar ve Bunlar Korunma Mecmuası & 1938 \\
\hline Hava Taarruzlarına Karşı Işıkların Söndürülmesi ve Karartılması Nizamnamesi & 1939 \\
\hline Hava Taarruzlarına Karşı Pasif Korunma Nizamnamesi & 1939 \\
\hline $\begin{array}{l}\text { Hava Hücumlarına Karşı Hayvanların ve Hayvanlardan Husule Gelen Yiyecek Maddelerinin } \\
\text { Korunmasına Dair Talimatname }\end{array}$ & 1939 \\
\hline Gönüllü Hastabakıcılık Kursları & 1939 \\
\hline Ticaret Gemilerinin Gaza Karşı Korunması Hakkında Nizamname & 1939 \\
\hline Yapılarda Pasif Korunma Bakımında Tatbik Olunacak Esaslar ve Sığınaklar Nizamnamesi & 1940 \\
\hline $\begin{array}{l}\text { Şehir Planlarının Tanziminde ve Mühim Bina Yerlerinin Tayininde Tatbik Edilecek Pasif Korunma } \\
\text { Şartlarına Dair Nizamname }\end{array}$ & 1940 \\
\hline
\end{tabular}


Olası bir savaş ihtimaline karşı bir dizi önlem alınmaya çalışılmıştır. İkinci Dünya Savaşı'na giden yolu dikkatle izleyen devlet yetkilileri savaş devam ederken dahi daima dikkatli davranmış ve tedbiri elden bırakmamıştır. İkinci Dünya Savaşı’nda zehirli gazlar etkin olarak kullanılmamakla birlikte bu konuda araştırma ve geliştirme faaliyeti devam etmiştir. Ülkelerin zehirli gaz stoku korkutucu hale gelmiştir. Savaşın sonunda büyük bir yıkıma sebebiyet veren atom bombası, savaşta zehirli gaz saldırısını tabiri caizse gözden düşürmüş ve devletler, nükleer teknolojiye yatırım yapma yarışına girmişlerdir. ${ }^{113}$

Ülkemizde silahlı kuvvetler bünyesinde hâlihazırda faaliyet gösteren Kimyasal Biyolojik Radyolojik Nükleer (KBRN) Savunma Özel Müdahale Birliği tehlike anında müdahale edecek ekipleri yetiştirmektedir. ${ }^{114}$ Ayrıca Afet ve Acil Durum Yönetimi Başkanlığı (AFAD) ülkede oluşabilecek olağandışı durumlar için önlem alma görev ve sorumluluğunda bulunmaktadır. AFAD sivil savunma ile kimyasal, biyolojik, radyolojik ve nükleer saldırılar karşısında etkin olarak görev yapmaktadır. ${ }^{115} \mathrm{Bu}$ konuda da Kimyasal, Biyolojik, Radyolojik ve Nükleer Tehlikelere Dair Yönetmelik yayınlanmış olup ${ }^{116}$ AFAD'ın ve diğer yetkili kurumların bu konudaki sorumluluğu belirlenmiştir.

\section{Teşekkür}

Çalışmanın araştırma ve hazırlanma aşamasındaki yardımlarından dolayı Prof. Dr. Nuran Yıldırım'a, Ecz. Mine Zanbak’a, Ecz. Erdal Kart'a ve Serdar Özdemir’e teşekkürü bir borç biliriz.

113 Devletlerin atom bombası teknolojisi ve atom bombasının üretilme aşamaları için bkz. Emre Dölen, Demokritos'dan Fukuşima 'ya Atomun Öyküsü (İstanbul: Türkiye Kimya Derneği, 2018): 183-246.

114 “TSK'nın Çok Özel 55 Adamı," erişim 2 Mayıs 2019, http://www.milliyet.com.tr/gundem/tsknin-cok-ozel-55adami-1870862

115 AFAD'ın kimyasal, biyolojik, radyolojik ve nükleer tehditlere yönelik çalışmaları ve uygulamaları için bkz. "Bilgilendirme," erişim 2 Mayıs 2019, https://www.afad.gov.tr/tr/23456/KBRN

116 T.C. Resmi Gazete, say1 28281, 3 May1s 2012. 


\section{EK 1}

Büyük Erkânı Harbiye Reisi Mareşal Fevzi Çakmak'ın

Maarif Vekâletine gönderdiği 20 Ağustos 1934 tarihli yazı

(İstanbul Tıp Fakültesi Personel Arşivi Ord. Prof. Dr. Tevfik Salim Sağlam dosyası)

20 A ğustos 1934

\section{Maarif Vekâletine}

1- Millî seferberlik talimatnamesinin ikinci kısmı ahkâmına tevfikan her vilâyette teşkil edilmesi icap eden (havaya karşı korunma komisyonları) ında gaz kursuna iştirâk ettirilmiş birer gaz hekimi bulundurmak suretiyle kursa iştirâk etmeyen diğer hekimler ila halka gazlardan korunma usulleri ve gazlanmışlara karşı yapılacak muamele hakkında salâhiyetle konferanslar verilmesi ve halkın tenvir ve irşat edilmesi faydalı olacağı ve bu maksat için her vilâyetten bir hekimin Ankara'daki Askerî gaz kursuna iştirâk ettirilmesi lüzumu evvelce arz edilmiş ve fakat iştirâk edeceklerin harcırah ve yevmiyelerinin teminindeki imkânsızlık karşısında hiç olmazsa yalnız merkezde bulunan ve hükûmet doktorlarıyla polis, itfaiye ve belediye memurlarının 1/Mayıs/1934 tarihinde Ankara'da açılacak olan gaz kursunda bulundurulmalarının temini Dahiliye Vekâleti Celilesinden rica edilmişti.

Şimdiye kadar Ankara'daki Askerî gaz kursuna sivil teşkilâttan Ankara'dan bir kimyager, dört doktor, Kırıkkale'den bir kimyager, Ankara ve İstanbul İtfaiye teşkilâtından dört memur Ankara'dan ve jandarma mekteplerinden altı jandarma, devlet demir yollarından üç doktor, dört mühendis ile İstanbul'dan bir profesör iştirâk etmiştir.

2- İdare-i Hususiye ve belediyelerin iktisadî buhran ve vergi kanunlarında yapılan tadilat ila varidatlarındaki tenakus dolayısıyla mezkûr idarelerin müteakip seneler içinde bu maksatla ihtiyaten kâfi tahsisat koymayacakları mütalâa olunmaktadır.

Bu mahzurun kısmen izalesine medar olmak üzere 27/5/1934 tarih ve 19576 numaralı yazı ile arz edilen:

a) Bundan sonra yetiştirilecek hekim ve kimyagerlerimizin muharebe gazları ve mikrop harbi hakkında bilgi ile mücehhez olmalarını temin etmek ve evvelce Fakülteden çıkmış bulunan hekimleri kurstan geçirmek üzere Üniversite'de Tip Fakültesi'nde bir kürsü tesisi,

b) Alelumum mektepler ve halk evlerinde muharebe gazları ve mikrop harbi hakkında her sene müteaddit konferanslar verilmesi suretiyle gençliğin ve halkın fikren ve manen ihzarı,

c) Gaz taarruzlarına karşı halkın emniyet ve sıhhatini korumakla mükellef idare amirlerinin gaz kursunda geçirilmesi,

d) Muharebe gazları ve hastalık mikroplarının tesirlerine karşı koruyucu tertibat alınması gibi, tedbire ilâveten icap eden teçhizat, alât ve edevat ve gaz maskelerile mücehhez Millî Müdafaa Vekâleti gaz mütehassısının riyasetinde iki kişilik bir heyetin evvelemirde demiryolu güzergâhındaki mühim şehir ve kasabalarda ehemmiyet ve vaziyetlerine göre ikmâl edilmemiş gazdan korunma teşkilâtını tesis ve verilecek konferanslar ve amelî tecrübeler ile halkın gazdan korunma hususunda tenvir edilmesinin faydalı olacağı mütalaasındayım.

Heyetin yol ve ikamet masraflarına gelince: ikamet masraflarının bulundukları şehir ve kasabaların hususi idare ve belediyelerince ve yol masraflarının da devlet demiryolları Umum Müdürlüğünce ihdas edilmiş olan halk ticaret biletlerinden istifade suretile dolaşılan vilâyetlerce bir nispeti muayyene dâhilinde teminin mümkün olabilecektir. Biletlerin bir aylık müddetli olanlarının birinci mevkileri altmış, ikinci mevkileri kırk liradır. Heyet beraberinde elli kiloluk numune eşya veya numune koleksiyonlarını da meccanen götürebilecektir. Binaenaleyh şayanı 
istiksar bir yekûn tutmayacak olan yol ve ikamet masraflarının vilayetlerce temininde müşkülât olmayacağını tahmin ediyorum.

3- Bunda başka memleketimizde açılan ve açılacak olan seyyar ve sabit sergilerde gazların tesiratı ve bunlara karşı tahaffuz çarelerinin teşhir edilerek halkın bu suretle de tenvir ve irşat edilmesi muvafık olur.

4- Radyolar vasitasile konferanslar verilmesinide gazlar ve bunlardan korunma hususunda halk1 tenvir edecek iyi bir vasıta telâkki etmekte ve bunun teminini mühim görmekteyim. Halk için havaya karşı koruma talimatının 59. Maddesinin birinci fikrası da bu mühim vasıtada istifade edilmesini amirdir.

5- Bütün bu tedbirlere rağmen her vilâyetin havaya karşı korunma komisyonlarında gaz kursu görmüş bir mütehassıs bulundurulması hususu ehemmiyetini muhafaza etmektedir. Bu cihetle her vilâyetin hususî idare veya belediyelerinin 1935 bütçesine tahsisat koyarak her vilâyetten kabiliyetli birer doktorun 1935 senesinde Ankara' da Askerî gaz kursundan geçirilmesinin ve 17/12/933 tarihinde Hilâl-i Ahmer merkezi umumisinde toplanmış olan komisyonun verdiği raporun bir karar bağlanmasının teminini Dahiliye Vekâleti Celilesinde ayrıca rica ederim, efendim.

6- Dahiliye, Millî Müdafaa, Sıhhat ve İçtimaî Muavenet, Maarif ve Nafia Vekâletlerine arz edilmiş ve Askerî Sıhhiye Müfettişliğine yazılmıştır.

B. E. Rs. [Büyük Erkânı Harbiye Reisi]

Müşir [Mareşal]

Fevzi [Çakmak]

\section{EK 2}

Vilayetlerde Açılacak Hava ve Zehirli Gazdan Korunma Kursları Hakkında Talimat [1936] (Sihhî İçtimaî ve İskâna Ait Kanun, Nizamname, Talimatname ve Kararnameler. Ankara: T. C. Sihhat ve İçtimaî Muavenet Vekâleti Neşriyatı No. 83, 1942, 434-445).

Madde 1. Hava ve zehirli gazdan korunma tedris malzemesi Kızılay cemiyetince Avrupa'dan getirtilmiş ve vilayetlere gönderilmiştir.

Madde 2. Vilayet merkezlerinde açılacak kurs ve konferanslarda, geçen 1934 senesi birinci kânunda Ankara'da açılmış olan gaz kursuna iştirak etmiş tabipler muallimlik edecektir. Ankara Genelkurmay Gaz Mektebi'nden yetişmiş tabip ve kimyager ve zabitlerden de istifade edilir.

Kurslar:

a) Kurslara iştirak edecekler şunlardır:

Hava harbinden korunmada Yurt Sihhat İşleri talimatının birinci kısmının 1, 2, 3 üncü maddeleri mucibince etıbba, kimyager, eczacı ve dişçiler, hemşireler, küçük sıhhat memurları, dezenfeksiyon memurları ve lazım gelen hasta bakıcı ve saire gibi yardımcılar.

Baytar, ziraat memurları, mühendis ve memurlar, jandarma, polis, itfaiye, zabitan ve küçük zabitan, mektep muallimleri, ticari ve sınaî kalabalık müesseselerin mümessilleri lazım gelen belediye memurları.

Bu kurslara vilayet ve kaza merkezlerinde yukarıda yazılı sınıflara mensup zevat sıra ile iştirak ettirilecekler ve kurs hitamında yapılacak müzakere tarzında imtihanlarda alacakları notlara göre ehliyetname verilecektir. 
Bu kurslar 15-20 gün devam edecek ve 1 numaralı program tatbik edilecektir.

Vilayet ve kaza merkezlerinin meslekleri ve vazifeleri icabı havadan korunma işleri ile alakadar, yukarıda yazılı kimselerin bu sene için hiç olmazsa 1/3'ü yetiştirilmek üzere kaç kere kurs açılması lazım geldiği ve mahal ve vaktinin tayini vilayetlere bırakılmıştır.

Konferanslar:

b) Dahiliye Vekâleti ile Sıhhat ve İçtimaî Muavenet Vekâleti talimatlarının hava ve zehirli gazlardan korunma hizmetleri ile ilgili kıldığı ve kılmadığı bütün devlet ve belediye memur ve mensupları ile ileri gelenlerinden ve okuyup yazanlarından başlamak üzere kadın ve erkek bütün halk için gece ve gündüz münasip zamanlarda sık sık konferanslar verilecek ve konferanslarda 2 numaralı program tatbik olunacaktır.

c) Halka verilecek konferanslar için Ankara Gaz Mektebi'nde ve vilayet merkezlerindeki kurslarda yetişen zatlardan iyi ehliyetname alanların münasipleri intihap ve tayin olunur. Her şehir ve kasabada aynı zamanda birkaç yerde konferans verilebilir. Tedris malzemesi bahislere göre konferansçılara taksim ve tevzi edilir. Ve mevzu değiştikçe aralarında tebdil olunur.

Madde 3.

a) Kurslar için yerine ve muktezasına göre halkevi, mektepler, hastane konferans salonlarından ve kimya, fizik, tabiiye laboratuvarlardan ve koleksiyonlarından istifade olunur.

b) Tatbikat ve gösterim için konferans binası bahçesinde veya civarında küçük mikyasta bir kuyu sığınak, yine konferans binasında veya münasip bir kâgir evin veya dairenin bodrum katında yapılacak yarım sığınak (muvakkat sığınak) umum için yapılacak tam sığınak ile bir gaz odacığı vücuda getirilmesi ve bunların yeniden yapılandırılacak veya ısmarlanacak veya elde bulunanlardan tedarik edilecek lazım cihazlarla teçhizi muvafik ve arzuya şayandır. Gösterim için mahalli askeri garnizonlarının havadan ve gazdan korunma teçhizat ve tesisatından istifade de mümkündür.

Madde 4. Kurs ve konferans mevzularını hazırlamak ve sığınakları, gaz odalarını yapmak ve teçhizlemek için lazım gelen malumatı toplamak üzere merkezde geçirilmiş kurs ve konferans notlarından, talimatnamelerden ve neşr olunmuş aşağıdaki isimleri yazılı eserlerden istifade olunur.

Halk için yazılmış eserler:

Tayyare ve Gaz Hücumundan Koruma -1930 - Dr. Hasan Kadri - İkbal Kitaphanesi - İstanbul.

Gaz Tehlikesi ve Koruma Çareleri - 1935 - Şakir Hazım Gökmen - Ulus Basımevi.

Gaz tehlikesi - 1935 - Kimyager Selahaddin Özyar - 11. Mintıka Etibba Odası.

Hava Tehlikesi - 1931- Mütekaidini Askeriye Cemiyeti tarafından neşrolunmuştur.

Zehirli Gaz ve Korunma -1935 Şefik Özgüler - Resimliay Basımevi - İstanbul.

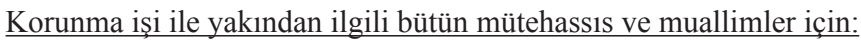

Semli Gaz Muharebesi ve Hastalıklar - 1928 - Dr. Hasan Kadri - İkbal Kitapevi.

Harp Gazları ve Korunması - 1934 - Dr. Mâzlum - Nuri Refet - Ankara Gaz Mektebi.

Muharebe Gazleri -1934- Nuri Refet - Ankara Gaz Mektebi.

Muharebe Gazları ve Korunma Çareleri - 1934 - Dr. Hüsnü - İstanbul Halıcıoğlu Yedek Subay Okulu.

La Guerre aéro-chimique et la Population civile, L. Izard et J. des Cilleuls - Paris-1933 - Edit. Charles-Lavauzelle.

L'Arme chimique et ses Blessures - Prof. Ch. Héderer et Marc Istin - Edit. Baillère - Paris.

Leitfaden der Pathologie und Therapie der Kampfgaserkrankungen von Dr. med. Muntsch - 1935

- Verlag Georg Thieme - Leipzig.

Grün und Gelbreuz von Dr. Hermann Büscher - 1932 - Verlag Johann Ambrosius Barth. 
Madde 5. Eldeki tedrisat malzemesinin bozulmaması için aşağıdaki kaidelere riayet lâzımdır:

A- Süzücü maskeler sühunet dercesi 10-20 rutubet dercesi 45-65 olan odalarda saklanır. Tavandan asma veya duvara mıhlama yüksek 1zgara raf üzerine evvela boş muhafaza ve bunun üstüne de boşluğu aşağı, yüzü yukarı gelmek ve ağızlığı ile gözleri öne bakmak üzere maske oturtulur. Maske hortumunda bunun etrafina çöreklenir. Tozlanmamak üzere üstüne bir bez örtülür. Farelerden korunmalıdır. Fare korkusu varsa 1zgara raflı asma tel dolap müreccahtır.

B- Süzgeçler uzun müddet saklanabilmek için yine aynı sühunet ve fakat 40-50 derce arasında rutubet derecesi ister. Maske başlıkları kauçukları hesabıyla kuruluktan, süzgeçler rutubetten bozulur. Bunun için süzgeçler aynı odada içi çinko kaplı ve muhkem kapalı sandıklarda muhafaza edilir. İhtiyaten bu sandıkların içerisine bir kapta cazibi rutubet bilama kloru kalsiyum veya kesif asit sülfürik konur.

C- Tripleks gözlük camlarını arasındaki sellon levhası ile bu gözlük camlarının buğulanmaması için iç içe konulmuş olan jelatinli ince sellon levhaları hem rutubetten ve hem güneş ve hararetten ve kuruluktan müteessir olmaması için aralarına mukavva parçaları koymak üzere istif edilmiş oldukları kutularında, süzgeçlerin konduğu içi çinko kaplı sandıklarda saklanması lazımdir.

D- Ayrıcı (tecrit) maske ile oksijen koklatma cihazı yine aynı odada ve fakat kendi ahşap sandıkları içinde güneş ziyasından, sıcak ve soğuktan ve tozdan müteessir olmayacak şekilde dolaplarda saklanir.

Bunların hortumlarını içine hava girmemek için iki uçtaki delikler lastik mantarlar ile tapalamayı unutmamalıdır. Kalevi hartuçları hiç rutubet almamak üzere ağıları fabrikadan geldiği gibi sıkı kapalı olarak içi çinko kaplı sandıklarda muhafaza edilmelidir. İcap ediyorsa sandık derununa cazibi rutubet maddeler konmalıdır. Mühürleri bir kere fark edilip de velev cüz'i bir zaman için kullanılmış bir kalevi hartucu talimden ve gösterimden gayri ciddi can kurtarma işlerinde asla kullanılmaz. Bunun için daima kullanılmamış yedek hartuç bulundurma lazımdır.

Oksijen bombaları güneş ve kaloriferi olmayan gölge ve serin yerlerde saklanmalıdır. Bunların saklandığı yerlerde asla ocak, soba, ateş yakmamalıdır. Patlamak suretiyle kazayı mucip olabilir. İçlerindeki oksijen kaçmamak için ağızları sıkı kapanmalıdır. Oksijen bombaları en yakın oksijen imla depolarında veya düzenlerinde şimdilik Ankara, İstanbul ve İzmir'de doldurulabilir.

E- Gaz elbiseleri de aynen 10 derece-i sühunet ve 45-60 rutubet dereceli gölgeli ve serin odalarda içi çinko kaplı gardıropta manken üzerine geçirilmiş veya askıya asılmış olarak saklanmalıdır.

F- Gaz fişekler ve kibritleri için de oksijen bombaları hakkındaki takayyüdat ister. Bunlara çoluk çocuğun dokunmasına ve kazaya meydan vermemelidir.

G- Tatbikat mümkün mertebe yüzü, gözü, ağzı, boynu ve elleri ciğerleri geçici hastalıklı olmayan şahıslar üzerinde yapılmalı ve yaptırılmalı. Zıykı nefes ve ilerlemiş kalp hastalı̆̆ı olanları da maske ve süzgeçle yürüyüş ve talim yapmaya bırakmamalıdır.

Maskelerin ve süzgeçlerin yere düşmesine bir yere çarpmasına ve zedelenmesine meydan vermemelidir.

Gerek süzücü ve gerek ayırıcı maske ve oksijen koklatma cihazları kullandıktan sonra gaz idrofille veya temiz tülbentle ağız ve el değen, nefesle buğulanan yerleri usuletle emdirerek silmeli ve sonra maskeleri taşıma bağlarından tutup havada sallayarak diğerlerini serin ve gölge cereyana bırakarak kurutmalıdır. Asla güneşe ve mangala tutmamalıdır.

Kış talimlerinde maskenin açıkta bırakılıp donmasına da meydan vermemelidir.

Maskeler talimlerde uzunca müddet kullanılmakla kirlenir. Bunun için vakit vakit ve lüzum gördükçe formol odasında bu yoksa yapılacak bir metre mikablık beton bir hücrede veya penceresiz veya küçük pencereli kâgir mahzenlerde veya kâgir alafranga abdesthanelerde (kap1 ve penceresi mazbut) maskeleri tavana veya bir sehpaya asılı olarak formol buharıla dezenfekte etmelidir. (Metre mikâbına 20 gram formol düşmeli) ve maske böyle formollu bir 
odada akalli 5 azami 12 saat kalmalıdır. Süzgeçler ve buğu tutmaz sellon levhaları formolda bozulacağından dezenfeksiyondan evvel bunları çıkarmayı unutmamalıdır.

Tedris Malzemesi Teferruatının Neye Yaradığını Bildiren Tarife

1- Maske çantası. (İki gözden deliklisi süzgeç, deliksiz büyüğü maske koymak içindir.)

2- Maske ve hortum. (Nasıl kullanılacağı malumdur.)

3- Kahve renkli A, zeytunî renkli B süzgeçleri küçük harp süzgeçleridir. Bunlar aktif kömür ve diatomit doludur. A süzgecinde B süzgecinden daha çok kömür vardır. (B maktaı) sanayide istimal edilebilir.

4- 39 numaralı mukavva kutuda bulunan içi selüloz döşeli alüminyum kapakta küçük süzgeçleri Arsinleri de süzmek üzere tamamlayan yaylı kapaklıdır. İcabında takılacaktır.

5- 89 numaralı süzgeç (Hochleistungsfilter) daha çok dayanıklı orta süzgeçtir. Bunun alt tabakasında selüloz, orta tabakasında kömür ve üst tabakasında diatomit vardır.

6- Büyük yassı süzgeç, kutusunda orta süzgeçten daha çok selüloz, kömür ve diatomit tabakalarını ihtiva eden büyük harp süzgecidir. (Büyük yassı süzgeç makta1)

7- Yukarısında mavi zemin üzerinde Degea $\mathrm{C}$ ve altta yapışık kaidenin yukarısında Degea CO Büchsel yazılı en büyük oval süzgeç maktaı humzu karbon süzgeci maktaıdır.

8- Sanayide, fabrikalarda müstamel muhtelif renkli 10 adet süzgecin kullanılmaları aşağıda yazılidir:

91 numaralı alüminyum süzgeç, kolloid halindeki toz ve dumanlardan korur ve kolloid süzgeç ismini alır.

Sarı ve zeytunî renkteki D markalı süzgeç, sanayi müesseselerinde hâsıl olan daha iri tozlara karşı kullanılan toz süzgecidir.

Sarı renkte E markalı süzgeç hamızı kibriti buharatını tevkif eden süzgeçtir;

Kırmızı renkli F markalı süzgeç yangınlardan hâsıl olan gazları tevkif eden itfaiye süzgecidir.

Mavi renkli G markalı süzgeç asit siyanhidriki tevkif eden süzgeçtir.

Mavi kahve renkli J markalı süzgeç siklonu tevkif eden süzgeçtir. (Siklon dezenfeksiyon esnasinda kullanılır.)

Yeşil renkli K markalı süzgeç amonyağı tevkif eden süzgeçtir.

Sarı kırmızı renkli L markalı süzgeç kükürtlü müvellidülmayı tevkif eden süzgeçtir.

Sarı ve mavi renkli M markalı süzgeç hem amonyağı ve hem de kükürtlü müvellidülmayı tevkif eden süzgeçtir.

Sarı ve kahve renkli R markalı süzgeç gazı kibriti, benzin, eter, kloroform gibi uzvî muhallilatı ve halojenleri ve mürekkeplerini tevkif eden süzgeçtir.

9- Sarı zarf içindeki ölçü şeridi maske tevzi olunacak insanların yüz ve alınlarının ölçüsünü almaya yarayan maskometredir. Maskometre şöyle kullanılır:

1. Safha: Maskometre zarfindan bozulmadan çıkarılır. Şeridi yukarıda olmak ve numaralı yüzü dışa bakmak üzere iki uçtan iki elle tutulur.

2. Safha: Săg el birinci safhadaki vaziyette kalmak üzere sol el ile şerit takılı ve maskometre yazılı parçanın üst kenarı ortasından tutulur ve iki parça birbirinden delikli mihver etrafinda zaviyeyi kaime teşkil edinceye kadar ayrılır.

3. Safha: Şerit takılı ve üzerinde maskometre yazılı kolu yazısı ile kendine bakmak ve ufkî vaziyette yukarı gelmek üzere köşeden sol el ile tutulur. Ufkî kolun altından uzanan sağ el ile şakuli kolun arkada kalan rakamlı parçasının ucundan baş ve işaret parmakları ile tutularak oklu uca gelinceye kadar açılır ve rakamlar kendine bakmak üzere hafifçe çevrilerek ucuna gelinceye kadar yukarı itilir. Bundan sonraki kullanış zarfın üzerinde yazılı ve çizilidir. (Bu usul ile kullanılmayan maskometre çabuk yırtılır. Yapılması da güçtür.) 
10- Büyük mukavva kutudaki kauçuk ceket ve pantolon iperit ve levizit gibi yakıcı maddelere karş1 koruyan gaz elbisesidir.

11- Siyah kauçuk çizmeler ile bunların içindeki lastik eldivenler yine aynı veçhile koruyan gaz çizmesi ve eldivenidir.

12- Küçük tahta sandık içindeki diatomit, aktif kömür granül kutuları ile klorasetofenon ve adamsit kibrit kutuları ve fişekler üzerinde muhtevileri yazılır.

13- Meşin kayış bağlı gaz numune sandığındaki numune şişelerinin üzerinde muhtevileri yazılıdır. Üzerinde (karışı gaz) yazılı olan şişede \% 60 klorpikrin, \% 20 sülfür klorür, \% 20 tetra kloru kalay vardir.

Bunları gösterir ve koklatırken dökülmemesine ve ele bulaşmamasına dikkat etmelidir. Bunlar ile beraber iperit ve fosgenin tesirlerini gösteren iki hastalık levhası vardır.

14- Henüz gümrükte olup arkadan gönderilecek olan ambalaj sandığında kendi orijinal tahta kutuları içinde 1 kıta müvellidülhumuza koklatma cihazı ve tecrit maskesi ile ayrıca bir de gaz fişeği tabancası bulunmaktadır.

1 numaralı Müfredat Program1

Kurslar için 15-20 Günlük

Umumi malumat olarak

1- Gelecek harplerde hava muharebesinin ehemmiyeti, tayyare ve zehirli gazların kısa bir tarihi ve askeri tasnifi ve tabiyesi. Tahrip, yangın, zehirli gaz bomba ve güllelerinin tesirleri. Ordu cephesi gibi, memleket içlerinin ve halkın taarruza uğrama tehlikesi ve şümulü. Taarruza maruz şehir, kasaba ve müesseselerin ve halkın hava taarruzunda koruma çarelerinin esasları.

Tatbikat: Bomba modelleri ve bunların tesirlerini gösteren levhalar gösterilmesi.

2- Tahrip yangın ve zehirli gaz bombalarının nevileri, şekilleri ve büyüklükleri, muhteviyatı. Tayyare ile nakil ve atılma tarzları. Bunların düştükleri yerlerin mukavemetine göre yaptıkları tahribatın derinliği ve genişliği. Zehirli gazların kullanılma ve atılma şeraiti vasıtaları ve tarzları. Zehirli gazların havada yerde ve eşya üzerinde kalma müddetleri. Zehirli maddelerin tayranında müessir olan havada ve yerde kalmasında zehirleyici tesirinin devam ve ademi devamında müessir olan avamil. İnsanlar, hayvanlar ve nebatlara tesirleri.

Sisler ve nevileri. Niçin kullanıldıkları vücutta yapabilecekleri tesirler.

Tatbikat: Bombaların yerde açtıkları çukura benzer surette kazılmış çukurlar gösterilmesi. Gaz kibritleri veya fişeklerin kullanılması.

3- Tahrip, yangın bombaları ve zehirli gaz ve sislerden korunmanın ehemmiyeti. Kaç sistem korunma olduğu. Toplu korunma sisteminin teşkilatı ve teçhizatı. Koruma siteminin vasıtaları (sığınak, dağıtma ve tahliye)

Tatbikat: Sı̆̆ınak resimleri, modelleri, hazırlanmış hakiki sığınak yerleri gösterilir.

4- Tek başına korunma vasıtaları (kendini koruma, ailesini koruma işleri) süzücü maskenin esaslı ve tafsilatl 1 anlatılması.

Tatbikat: Maskelerin ve elbiselerin en ince teferruatına kadar gösterilmesi. Kullanılması ve kullandırılması. Maske talim ve terbiyesinin ehemmiyetinin bildirilmesi.

5- Ayırıc1 (tecrit) maskenin esaslı ve tafsilatlı surette anlatılması ayırıc1 maskenin en ince teferruatına kadar izahı. Kullanma yeri ve zamanı ve kimlerin kullanacağı.

Tatbikat: Ayırıcı maskenin en ince teferruatına kadar gösterilmesi. Kullanılması ve kullandirılması.

6- Gaz elbiselerinin ve merhemlerinin esaslı ve tafsilatlı surette anlatılması.

Tatbikat: Gaz elbisenin en ince teferruatına kadar gösterilmesi, kullanılması ve kullandırılması. Ehli hayvanların ve kuşların da koruma vasıtaları (süzücü maske ve kafes)

7- Maskeler ve gaz elbiselerinin ve teferruatının muhafaza, depo edilmesi, halka tevzi tarzı (maskometre) maske muayene ve tecrübesi.

8- Düşman tarafından atılmış gazların keşfi usulleri. Bunun için lazım gelen teşkiller (ekip ve laboratuvar) aletler ve miyarlar (detektör) 
Tatbikat: Elde mevcut veya mahalli laboratuvarlardan tedarik edilebilecek miyarların ve detektörlerin hiç olmazsa mavi ve kırmızı turnusol kâğıtları ile asit ve esasların nasıl tefrik edildikleri gösterilmek suretiyle bir fikir verilmesi.

Gazlanmış muhtelif yerler, binalar, elbise ve eşyanın temizlenmesi usulleri. Bunun için lazım gelen teşkiller, aletler, vasıtalar ve kimyevi maddeler. (gazlanmış insanları temizleme teşkil ve vasitaları ayrıca bahis olunmalıdır.)

Tatbikat: Tedarik edilecek kimyevi tatbik maddeleri ile kireç kaymağı serpme arabaları, süpürme cihazı ve kullanılmasını göstermek.

Gaz arama ekipleri ile temizleme ekiplerinin müşterek faaliyeti, gazlanmış bir şehir veya kasabada gaz arama ve temizleme ekiplerinin işi bitince ve temizliğin bitiği ilanına kadar halkın riayet etmesi lazım gelen koruma kaideleri.

Sıhhiye Sınıfi için Devam Edilecek Tafsilat:

9- Tahrip ve yangın bombalarının vücutta husule getirdikleri yaraların, yanıkların, fosforla karışık yara ve yanıkların nevileri, araz, seyri, enzarı, ilk bakım, nakil ve tedavileri.

Hem yaralı ve hem gazlıların tefrik, teşhiş ve tedavileri

Tatbikat: Elde mevcut muhtelif yara resimleri, levhaları ve fosfor parçalarının nasıl yandığını su temasında sönmediğini gösterip ensice içinde de böylece yanmaya devam edeceği fikri verilecektir.

10- Alelumum zehirli gazların vücuda tesirlerindeki zaman ve kesafet amilleri. (Zaman x kesafet= ölüm hasılası yani Haber formülü) nün ve tahammül derecesinin haddi azamisi = ölümün başlangıç haddi meselesinin izahı.

Beyaz salip (gözyaşı getiren) zehirlerin isimleri, formülleri, fiziki ve fizyolojik tesirleri gözlerde husule getirdikleri afetin arazı, seyri, enzarı ve ilk bakım ve esas tedavileri, muzadı istidbabları. Tatbikat: Elde mevcut beyaz salip gazları herkese koklatılır. Beyaz salip kibriti yakılır. Gözde husule gelen afeti tasvir eden levhalar, resimler veya mulajlardan elde mevcut olanı gösterilir.

11- Mavi salip (aksırtıcı ve kusturucu) gazların isimleri formülleri fiziki ve kimyevi vasıfları, fizyolojik tesirleri. Yukarı teneffüs yolları ve sair aza ve bilhassa cilt üzerinde hâsıl ettikleri afetin arazı, seyri, enzarı, ilk bakım ve esas tedavileri, muzadı istidbabları.

Tatbikat: Mavi salip gaz numunelerinden elde mevcut olanının gösterilmesi ve kullanılması; mavi salip kibritinin yakılması suretiyle tecrübeler yapılır. Bir tecrübenin varsa gaz odasında veya buna benzer odada maskeli veya maskesiz olarak tekrarı maskenin faydasını göstermek bakımından faydalıdır. Bu gazların tevlit ettikleri hastalık levhalarından mevcut olanları gösterilir.

12- Yeşil salip (boğucu) gazların muharriş ve olmayan nevilerinin isimleri, formülleri, fiziki ve kimyevi vasıflar, fizyolojik tesirleri. Teneffüs yolları ve ciğerleri tali olarak kalp, deveran cümlesi ve sair azada husule getirdikleri afetin arazı, fizyopatolojisi, seyri, enzarı, ilk bakım ve esas tedavileri, muzadı istidbabları.

Tatbikat: Bu grup ait gaz numuneleri (klor, klor pikrin gibi) gösterilir ve koklatılır. Hastalığ gösteren mulaj levhalardan elde mevcut olanları gösterilir.

Tembih: beyaz, mavi ve bilhassa yeşil gaz fişeklerinin dar ve basık tavanlı yerlerde kullanılmasından sakınmalı.

13- Sarı salip (yakıcı) gazların isimleri, formülleri, fiziki ve kimyevi vasıflar, fizyolojik tesirleri, cilt teneffüs yollarında, gözlere ve sair azada husule getirdikleri afetin arazı, fizyopatolojisi, seyri, enzarı, ilk bakım ve esas tedavileri, muzadı istidbabları.

Tatbikat: İperit ve levizit numunelerinde elde mevcut olanlar gösterilir, kullanılır. Hastalık levha ve mulajları gösterilir.

14- Asit siyanidrikle, humzu karbon ve nitröz gazlarının fiziki ve kimyevi vasıfları, fizyolojik tesirleri, cilt teneffüs yollarında, gözlere ve sair azada husule getirdikleri afetin arazı, fizyopatolojisi, seyri, enzarı, ilk bakım ve esas tedavileri, muzadı istidbabları.

Tatbikat: Suni teneffüs metotlarının bilfiil gösterilmesi, suni teneffüs cihazlarının varsa resimlerinin gösterilmesi. 
15- Sisler ve zehirli sisler. Terkipleri, formülleri, fiziki ve kimyevi vasıfları bunların vücut üzerindeki tesirleri. Buna tedabir ve bunlardan hasıl olan arazların tedavisi.

Tatbikat: Elde mevcut sis kutularından birinin yakılarak gösterilmesi.

Haşiye:

A) Mühendis ve mimarlara hava tehlikelerinden korunma noktayı nazardan şehirlere resmi ve hususi mebaninin ticari ve sınaî müesseselerin nakil vasıta ve yollarının su, elektrik, hava gazı, telefon kanallarının ve lağımlarının tesisi planlarında yapılması lazım gelen tadilat ve bunların harap olanlarının hemen tamir edilip işletilmesi için lazım gelen tamir ve termim ekiplerinin teşkil ve teçhizatı ve saire hakkında hususi malumat.

B) Zabıta ve seyrüsefer memurlarına ve bunların muavin teşkilatına: düşman gözetlemek, dinleme haber alıp verme, alarm tertibatı, zabıt ve zabit, asayiş, münakalatın ve gidiş gelişin tanzimi, paniği mümanaat. İcabında tahliye ve dağıtma, halkın sığınaklara girip çıkması, sığınak inzibat amirliği, umumi sevk ve idare hakkında hususi malumat.

C) Belediye memurları ile kalabalık sanayi ve ticaret müesseseleri mümessillerine başında bulundukları şehir, kasaba ve müessesler sekenesinin gıda ve su ihtiyacının ve ihtiyatının ve bunların gaz ile zehirlemekten vikâyesi için yapılması lazım gelen mahfuz depolar ve sarnıçlar, cari suyun kesilmesi halinde evvelce açılması lazım gelen ihtiyat kuyular, umumi sığınaklarla evlerde yapılacak muvakkat sığınakların teçhizi için lazım gelen malzemenin tedarik ve izharı ve ihtikârdan muhafazası vs. hakkında malumat.

\section{Numaralı Müfredat Programı (Konferanslar için )}

Her konferansta bir maddesi söylenecek.

1- Gelecek harplerde hava muharebesinin ehemmiyeti, tayyare ve zehirli gazların kısa bir tarihi ve askeri tasnifi ve tabiyesi. Tahrip, yangın zehirli gaz bomba ve güllelerinin tesirleri. Ordu cephesi gibi memleket içlerinin ve halkın taarruza uğrama tehlikeli ve şümullü. Taarruza maruz şehir, kasaba ve müesseselerin ve halkın hava taarruzundan korunma çarelerinin esasları.

Tatbikat: Bomba modelleri ve bunların tesirlerini gösteren levhalar gösterilmesi.

2- Tahrip, yangın ve zehirli gaz bombalarının nevileri, şekilleri ve büyüklükleri muhteviyatı. Tayyare ile nakil ve atılma tarzları. Bunların düştükleri yerlerin mukavemetine göre yaptıkları tahribatın derinliği ve genişliği.

Zehirli gazların kullanılma ve atılma şartları vasıtaları ve tarzları. Zehirli gazların havada, yerde ve eşya üzerinde kalma müddetleri. Zehirli maddelerin uçmasında, havada ve yerde kalmasında, zehirleyici tesirinin devam ve âdemi devamında müessir olan avamil. İnsanlar, hayvanlar ve nebatlara tesirleri.

Sisler ve nevileri, niçin kullanıldıkları. Vücuda yapabilecekleri, tesirleri.

Tatbikat: Bombaların yerde açtıkları çukurlara benzer surette kazılmış çukurlar gösterilmesi. Gaz kibritleri veya fişekleri kullanılması.

3- Tahrip, yangın bombaları ve zehirli gazlardan korunmanın ehemmiyeti. Kaç sistem korunma olduğu. Toplu korunma sisteminin teşkilatı ve teçhizatı. Korunma sisteminin vasıtaları. (sı̆̆ınaklar, dağıtma ve tahliye)

Tatbikat: Sığınak resimleri, modelleri, hazırlanmış hakiki sığınak yerleri gösterilir.

4- Tek başına korunma sistemi (kendini koruma ailesini koruma işleri) süzücü maskenin esaslı ve tafsilatl surette anlatılması.

Tatbikat: Maskelerin en ince teferruatına kadar gösterilmesi kullanılması ve kullandırılması. Maske talim ve terbiyesinin ehemmiyetinin bildirilmesi. (takılıp çıkarma kaideleri ile)

5- Ayırıc1 (tecrit) maskesinin esaslı ve tafsilatlı surette anlatılması. Ayrıcı maskenin en ince teferruatına kadar izahı. Kullanma yeri ve zamanı ve kimlerin kullanacağı.

Tatbikat: Ayırıcı maskenin en ince teferruatına kadar gösterilmesi. Kullanılması ve kullandırılması. (takılıp çıkarma kaideleri ile) 
6- Gaz elbise ve merhemlerinin esasl1 ve tafsilatlı surette anlatılmas1.

Tatbikat: Gaz elbisenin en ince teferruatına kadar gösterilmesi kullanılması ve kullandırılması. (Giyilip çıkarma kaideleri ile)

Ehlî hayvanların ve kuşların da korunma vasıtaları olduğu (süzücü ve maske ve kafes)

7- Maskeler, gaz elbiselerinin ve teferruatının muhafazası. Depo edilmesi, halka tevzi tarzı (maskometre) muayene ve tecrübesi.

Tatbikat: Maskometre, maske emme, gaz odası tecrübeleri ile maskenin uyup uymadığını göstermek.

8- Düşman tarafından atılmış gazların keşif usulleri. Bunun için lazım gelen teşkilleri (ekipler ve laboratuvar) aletler ve miyarlar (detektörler)

Tatbikat: Elde mevcut veya mahallî laboratuvarlardan tedarik edilebilecek miyarların ve detektörlerin hiç olmazsa mavi ve kırmızı turnusol kâğıtları ile asit esasları nasıl tefrik edildikleri gösterilmek suretiyle bir fikir verilmesi.

Gazlanmış muhtelif yerler, binalar, elbise ve eşyanın temizlenmesi usulleri bunun için lazım gelen teşkiller, aletler, vasıtalar ve kimyevi maddeler (gazlanmış insanların temizlenme teşkil ve ekiplerinden ayrıca bahsedilmelidir.)

Tatbikat: Tedarik edilecek kimyevi takdir maddeleri ile kireç kaymağı serpme arabaları, püskürtme cihazları vs. kullanılmasını göstermek.

Gaz arama ekipleri ile temizleme ekiplerinin müşterek faaliyeti. Gazlanmış bir şehir veya kasabanın gaz arama ve temizleme ekiplerinin işi bitinceye ve temizliğin bittiği ilanına kadar halkın riayet icap eden korunma kaideleri.

\section{EK 3}

Hava Hücumlarından Korunma Cemiyeti Beyannamesi

("Hava Hücumlarından Korunma Cemiyeti Beyannamesi," Cumhuriyet 21 Teşrin-i Evvel [Ekim] 1933, 6).

Saygilı yurttaşlar,

Ulu rehberimizin cihan sulhunu istihdaf eden ve bütün insanlığa refah ve saadet getirmeye matuf yüksek siyasetlerini bütün bir tazimle yâd ve hükümetimizin işaret yollardan yürüyerek varmak istediği mukaddes gayeye ulaşmasını derin bir hürmetle temenni eden hava hücumlarından korunma cemiyeti de, bütün dünyada iman haline gelen "hazırlık yapmak, harp aranmaktan ziyade sulh istemek demek olduğu" düsturunu kendine rehber bildiğinden sulh gayesile aynı nurlu yollardan ve aynı mukaddes hedefe yürüyen bir varlık olduğunu bütün yurttaşlara büyük saygılarla arz etmeği her şeyden evvel kendisine bir vecibe tanır.

Hepimiz biliriz ki, ezelden beri insanlar düşmanlarıyla karşılaşınca, en keskin silahlarını kullanırlar; hele düşmanlarını gafil avlarlarsa bir anda ve pek kolaylıkla dileklerine ermeği isterler.

$\mathrm{Bu}$ şaşmaz kaide göz önünde tutulunca, amansız bir harp vasıtası olduğu Büyük Harpte tecrübe edilen zehirleyici gazlardan gelecekte de kullanılacağına hatta savaşların tamamen "kimya harbi" şekil ve suretinde yapılacağına hüküm vermekte hata ve mübalâğa yoktur.

Araştırılırsa, birçok sebepler dahi bu kimyevî silahın kullanılması lehindedir. Meselâ:

1- Hasma karşı kullanılması kolaydır,

2- Maddî be manevi tesirleri diğer silahlardan çoktur,

3- Fazla telafat verdirici ve saffi harp harici biraktırıcı,

4- Hazerdeki kimya müesseselerinin harpte az zamanda zehirleyici gaz yapabilecek hale çevrilmesi iktisaden faydalı ve ehemmiyetlidir, 
5- Hele, sulh ihtiyaçlarını tatmin perdesi altında kimyevî istihsalâtı düşmandan gizleyebilmek mühim bir noktadır,

6- Hususile, zehirli gaz bombalarını atacak hava kuvvetlerini hazerde ticari şekil ve mahiyette aleddevam ve kolaylıkla çoğaltmak itibariyle,

7- Ve hassaten bu noktaları göz önünde tutarak hasmın yapacağı hesapların neticesi olarak cihanın bugünkü vaziyetinden siyasî mahiyette birçok faydalara hizmet etmek bakımından çok çok değerlidir.

İşte bu kabil mülahazalar bütün milletleri hava kuvvetlerini kimya ve sanaiiyini inkişaf ettirmek yolunda sonsuz rekabetleri gittikçe artan bir çelişkiler sürüklemektedir.

Ve gene hepimiz biliriz ki, bugünün muharebe usullerine göre, düşmanın yalnız ordusunu ezmek veya düşman yurdunun bir parçasını koparmakla nihaî zafer elde edilemez. Böyle nihaî bir zaferi istihdaf eden düşmanlar için, memleket dâhilinde ordu besleyecek ve savaşı uzatacak canlı cansız ne varsa hemen yok edilmek raddesinde muvaffak olmak lazımdır ki, bu da ancak düşman yurduna hâkim ve dilediğini yapmağa kadir bir üstünlük temin etmekle mümkündür.

İşte bu çok belli sebeplerle umumileşen kanaatlere göre denilebilir ki, düşmanın hava kuvvetleri ilk iş olarak memleket içine şehir ve kasabalara ve hatta köylere varıncaya kadar anında saldıracaklardır. Eğer buna karşı daha hazerde iken tedbirler almamış, hiç olmazsa lazım olan bilgiler edinilmemiş ise büyük felaketler mukadderdir.

Bu görünür tehlikenin bütün etrafıyla kavratıldığı memleketlerde en yüksek makamlardan başlayarak adım adım şehir ve kasabalar belediyelerine kadar inen mahalli ve idari korunma teşekkülleri yapıldığı gibi bizzat halkın kendi selameti için alacağı korunma tedbirleriyle alâkadar olmak üzere hususî ve millî teşekküller de vücuda getirilmiştir.

Bunlara bakarak aziz yurdumuzda da hava tehlikesine karşı korunma tedbirleri almakta halkımız ögüt vermek ve elbirliği ile yapılacak hazırlıklarda yol göstermek maksadıyla "Hava Hücumlarından Korunma Cemiyeti” teşekkül etmiş ve işe başlamıştır.

Her müşkülü sarsılmaz bir iman ile yenen ve bütün milletlerin takdir ve tahsinlerine mahzar olan asil halkımızın başaramayacağı hiçbir zorluk yoktur; yeter ki yapılacak ve yapılması lazım gelenler bilinsin de bu hedef etrafinda yurdumuza ve yuvalarımıza duyduğumuz bir sevgi ile toplanılsın. "Hava Hücumlarından Korunma Cemiyeti'nin teşekkülündeki esas maksat yurdunu ve yuvasını seven yurttaşlara bu bilgiyi ve birikimi temindir. 
EK 4

Zehirli Gazlardan Korunma Konusunda Yayınlanmış Kitaplardan Bazı Örnekler
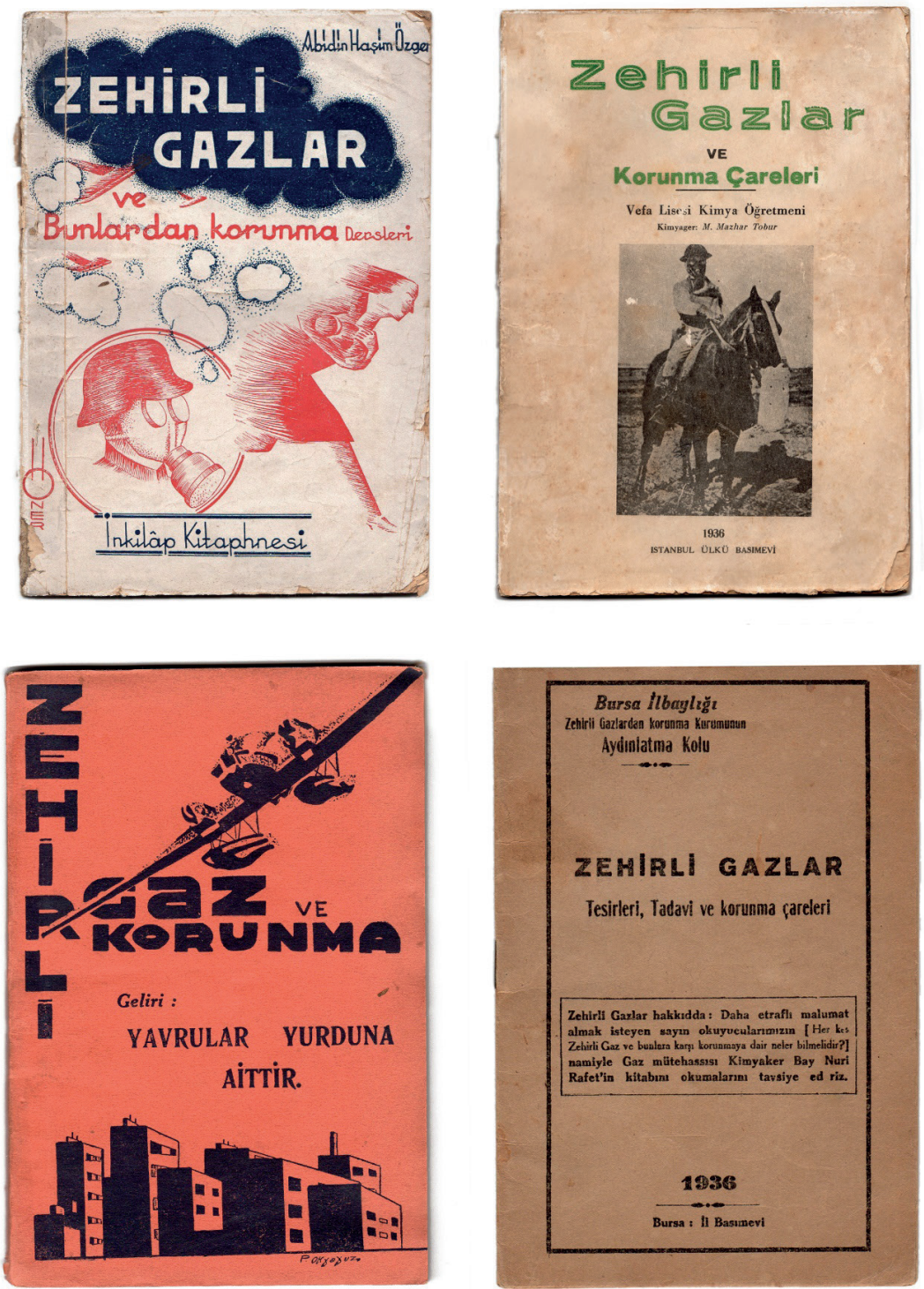

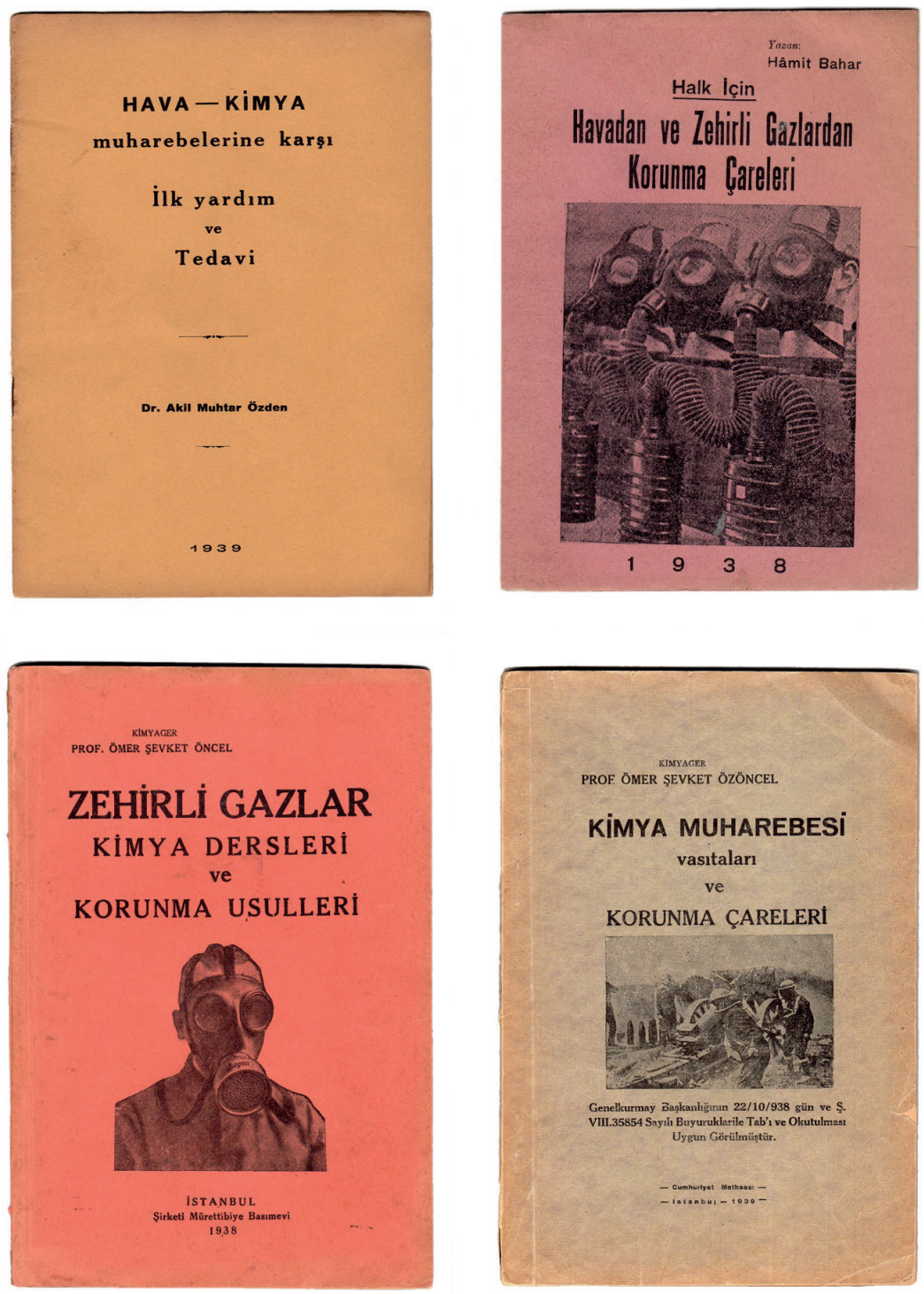

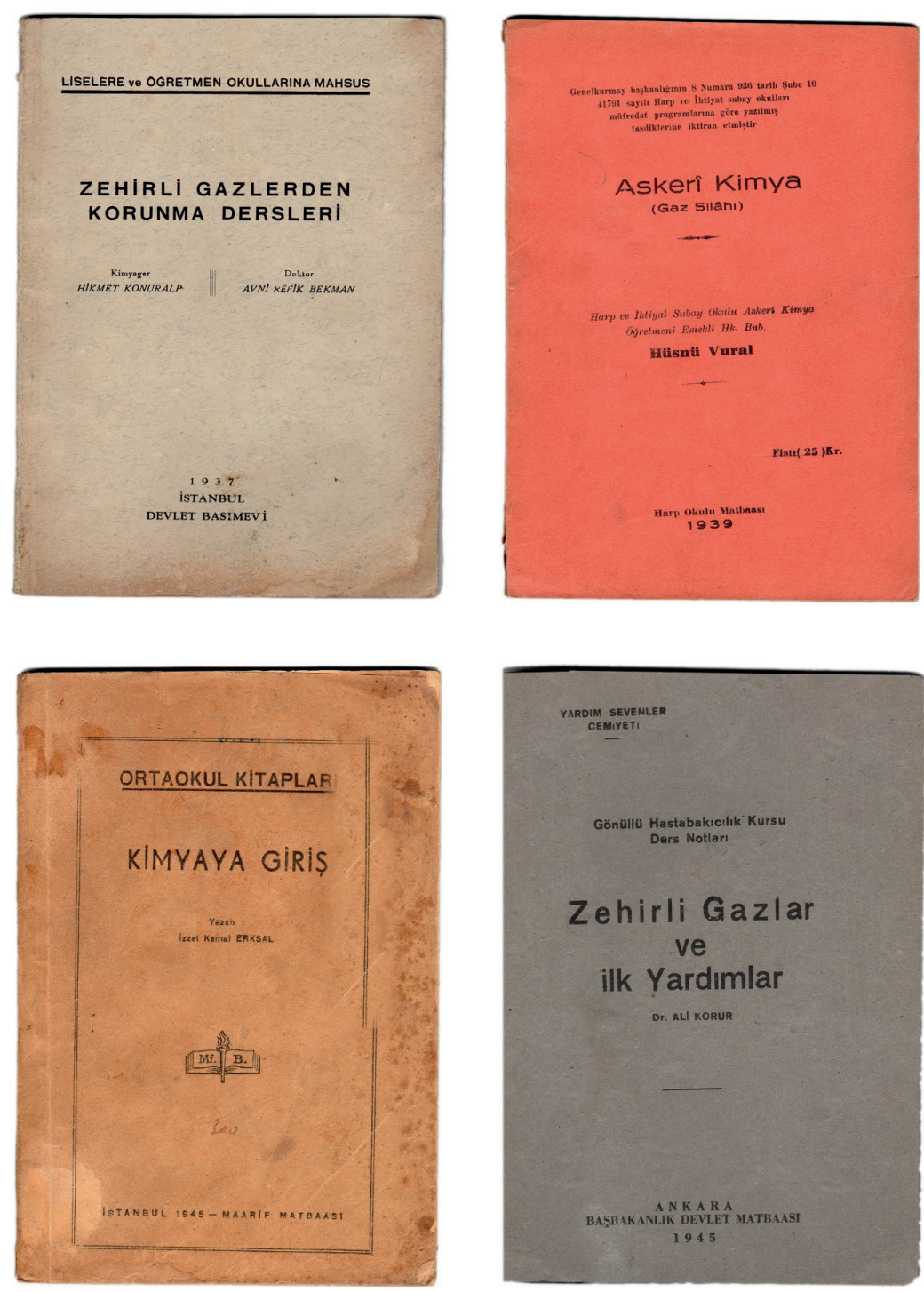

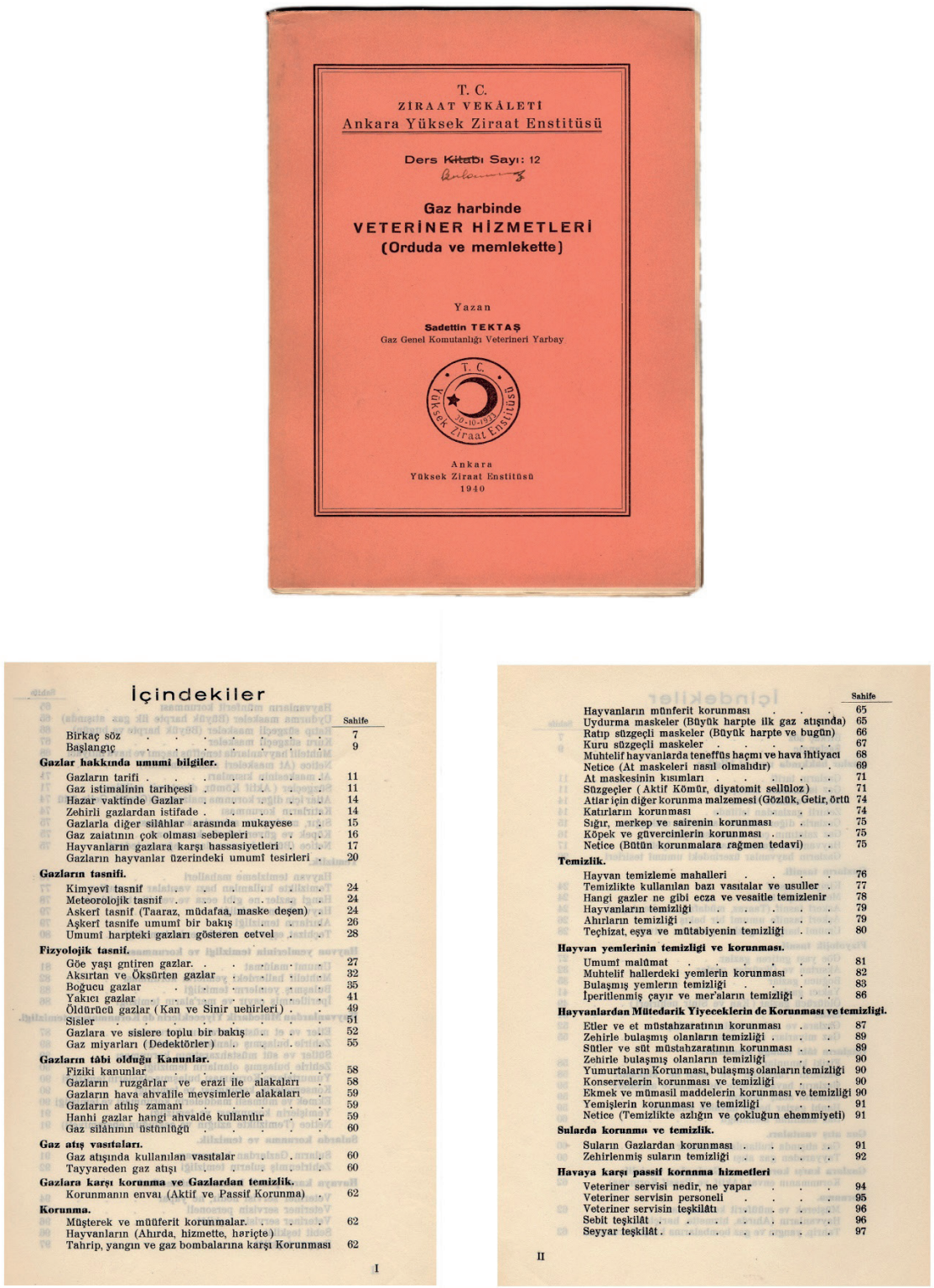


\section{KAYNAKÇA / BIBLIOGRAPHY}

\section{Arşiv Kaynakları / Archival Sources}

Başbakanlık Cumhuriyet Arşivi (BCA)(Ankara)

Başbakanlık Muamelat Genel Müdürlüğü: B.MGM 30.10/45.292.19, 13 Şubat 1929; B.MGM 30.10/51.331.4, 20 Şubat 1937; B.MGM 30.10/51.332.9, 12 Temmuz 1939; B.MGM 30.10/51.332.17.2, 8 Kasim 1939;

B.MGM 30.10/51.332.17.3, 8 Kasim 1939; B.MGM 30.10/51.332.17.4, 8 Kasim 1939.

Başbakanlık Kararlar Daire Başkanlığı: B.KDB 30.18.1.2/66.60.010, 15 Temmuz 1936; B.KDB 30.18.1.2/90.13.1, 3 Şubat 1940; B.KDB 30.18.1.2/94.21.14, 17 Mart 1941.

Siyasi Partiler Cumhuriyet Halk Partisi (SP. CHP) 490.1/1363.523.3, 12 Ağustos 1938.

Eyüp Talha Kocacık Koleksiyonu (İstanbul)

1930 ve 1932 yıllarında yapılan askeri gaz tatbikatlarına ait fotoğraflar.

1939 yılında Fatih Kaymakamlığı'ndan verilen diploma.

Emre Dölen Koleksiyonu (İstanbul)

1938 yılında Fatih Kaymakamlığı'ndan verilen diploma.

Gümüşsuyu Hastanesi’nden verilen Gönüllü Hemşirelik diploması

Istanbul Üniversitesi İstanbul Tıp Fakültesi Personel Arşivi (İstanbul)

Ord. Prof. Dr. Tevfik Salim Sağlam dosyası (Fevzi Çakmak’ın Maarif Vekâletine yazdığı 20 Ağustos 1934 tarihli yaz1s1)

\section{Basılı Kaynaklar / Printed Sources}

Bekman, Muzaffer. Veteriner Tarihi. Ankara: Ankara Basım ve Ciltevi, 1940.

Benhür, Çağatay, ve Mahir Selim Akçakaya. "İkinci Dünya Savaşı Sırasında Konya'da Alınan Askerî Önlemler." Gazi Akademik Bakış 5, 9 (Kış 2011): 171-187.

“1937-1938 Senesi Kış Devresinde İstanbul Zehirli Gaz Kurslarına Devam Edenlerin Listesi,” Zehirli Gazlar ve Bunlardan Korunma Mecmuası 1, 2 (1 Ağustos 1938): 19.

“1937-1938 Yılı Birliğin Mesai Raporudur.” Farmakoloğ 8, 4-6 (1938): 51-53.

[Boysan], Mazlum. “Zehirli Gazlar ve Biz.” Askeri Sihhiye Mecmuası 62, 2 (1933): 152-158.

[Boysan], Mazlum. “Zehirli Gazlar ve Biz.” Askeri Sihhiye Mecmuası 62, 3 (1933): 179-189.

Cephe Gerisinin Havaya Karşı Müdâfaa ve Muhâfazası Talîmâtnamesi. İstanbul: Askerî Matbaa, 1928.

Coşğun Kandal, Sena. "Zehirli Gaz Saldırılarına Karşı Halkın Bilinçlendirilmesi ve Eğitimdeki Yansıması: Gazdan Korunma Dersi (1931-1940).” Turkish History Education Journal 5, 2 (2016): 549-573.

Dağ, Murat. "Bir Şehir Efsanesi Olarak “Tak-Takı”nın Gizemi ve Fransızların Zehirli Gaz Kullandığının İşareti.” Gaziantep Üniversitesi Ayıntâb Araştırmaları Dergisi 1, 1 (2018): 63-68.

Develioğlu, Ferit. Osmanlıca-Türkçe Ansiklopedik Lûgat. Ankara: Aydın Kitabevi Yayınları, 2010. 
Dinçer, Ferruh. “Türkiye'de Askeri Veteriner Hekimlik Tarihi Üzerinde Araştırmalar-II.” Ankara Üniversitesi Veteriner Fakültesi Dergisi 27, 1-2 (1980): 246-272.

[Dirim], Hasan Kadri. Semli Gaz Muharebesi ve Hastalıkları. İstanbul: Kader Matbaası 1926.

Dölen, Emre. Demokritos'dan Fukuşima 'ya Atomun Öyküsü. İstanbul: Türkiye Kimya Derneği, 2018.

Dölen, Emre. Kimya Tarihinden Kesitler. İstanbul: Türkiye Kimya Derneği, 2018.

Dölen, Emre. Türkiye Üniversite Tarihi 2: Cumhuriyet Döneminde İstanbul Darülfünunu (1922-1933). İstanbul: İstanbul Bilgi Üniversitesi, 2010.

Erkekoğlu, Pınar, ve Belma Koçer-Gümüşel. "Kimyasal Savaş Ajanları: Tarihçeleri, Toksisiteleri, Saptanmaları ve Hazırlıkl Olma." Hacettepe University Journal of the Faculty of Pharmacy 38, 1 (January 2018): 24-38.

Gazdan Korunma Talîmâtnâmesi. İstanbul: Askerî Matbaa, 1932.

Halk İçin Havaya Karşı Korunma Talimatı D. 86. Ankara: Büyük Erkânıharbiye Reisliği Matbaası, 1931.

Karabulut, Umut. "Davetsiz Misafiri Beklerken İkinci Dünya Savaşı Türkiyesi’nde Pasif Güvenlik Önlemleri (1939-1940).” Çăgdaş Türkiye Tarihi Araştırmaları Dergisi 14, 28 (Bahar 2014): 199-223.

Kocacık, Eyüp Talha. Farmakoloğ Dergisinin Özetli Bibliyoğrafyası ve İncelemesi. İstanbul: Eczacılık Tarihi Araştırma Derneği, 2016.

Korur, Ali. Gönüllü Hastabakıcılık Kursu Ders Notları Zehirli Gazlar ve İlk Yardımlar. Ankara: Başbakanlık Devlet Matbaas1, 1945.

Korur, Nuri Refet. “Gazların Tarihçesi.” Kimyager 3, 9 (1935): 152-160.

Kutkan, Nuri. Zehirli Gaz Konferanslarım. Eskişehir: Yıldız Basımevi, 1935.

M. N. “Almanya Ne Yapabilir? Umumi Harpteki Askerî Dehadan Korkuluyor.” Cumhuriyet, 3 Teşrin-i evvel [Ekim] 1932.

Lopez, Munoz F., P. Garcia Garcia, ve C. Alamo. "The Pharmaceutical Industry and the German National Socialist Regime: I.G. Farben and Pharmacological Research." Journal of Clinical Pharmacy and Therapeutics 34,1 (2009): 67-77.

“Meslek Haberleri." Farmakoloğ 4, 7-9 (1934): 900; 7, 3-4 (1937): 65-85; 8, 10-13 (1938): 131-132.

[Mirel], Fuad Mehmet. "Kimya-y1 Harb.” Türk Eczacı Âlemi 1, 1-2 (1928): 21-29.

Muharabe Gazlarından Korunma Talîmâtnâmesi. İstanbul: Askerî Matbaa, 1927.

Muharabe Gazlarından Korunma Malzemesinin Hazer Vaktinde Muhâfaza ve Bakımına Dâir Talîmât: Müsvedde Halinde. İstanbul: Askerî Matbaa, 1927.

Özden, Akil Muhtar. Hava-Kimya Muharebelerine Karşı İlkyardım ve Tedavi. İstanbul: Ahmed İhsan Basımevi, 1939.

Sedad. Gaz Muharebesi. Dersaadet: Matbaa-yı Askeriye, 1921.

Seyhun, Gülhan. Tıp Tarihimizde Askerî Sağlık Hizmetleri II. Dünya Savaşı Dönemi. İstanbul: Altınbaş Üniversitesi Yayınları, 2018.

"Sihhî Ayniyat Komisyonları.” Farmakoloğ 18, 9 (1948): 292

Sıhhî-İctimai ve İskâna Ait Kanun, Nizamname, Talimatname ve Kararnameler. Ankara: Sihhat ve İçtimaî Muavenet Vekâleti, 1942.

Tektaş, Sadettin. Gaz Harbinde Veteriner Hizmetleri (Orduda ve Memlekette). Ankara: Yüksek Ziraat Enstitüsü, 1940. 
Toprak, Zafer. "Türkiye'de Barış Ortamında Savaş Travması: Hava Taarruzuna Karşı Pasif Korunma." Toplumsal Tarih 163 (2007): 40-47.

Türkçe Sözlük, 10. bs. Ankara: Türk Dil Kurumu, 2005.

\section{Tezler / Dissertations}

Çetin, Sabit. "İkinci Dünya Savaşı'nda İstanbul ve Trakya'da Alınan Tedbirler: Pasif Korunma ve Tahliye.” Yüksek Lisans tezi, Ankara Üniversitesi, 2008.

Özlü, Hüsnü. "II. Dünya Savaşında Günümüze Türkiye'de Savunma Sanayii’nin Gelişimi (1939-1990).” Doktora tezi, Dokuz Eylül Üniversitesi, 2006.

\section{Gazete Yazları / Articles from Newspapers}

Akşam, 20 Nisan 1939.

“Ankara'da Bir Zehirli Gaz Kursu Açıldı.” Cumhuriyet, 13 Ağustos 1935.

"Bir Şimendifer Memurunun İcadı.” Cumhuriyet, 21 Haziran 1934.

"Boşa Çıkan Zehirli Gaz İlacı.” Cumhuriyet, 10 Mart 1934.

"Bursa'da Zehirli Gaz Kursları." Cumhuriyet, 19 Nisan 1939.

“Bursa'da Zehirli Gaz Kursu.” Cumhuriyet, 14 Nisan 1938.

"Bursa'daki Zehirli Gaz Kursları." Cumhuriyet, 20 Mayıs 1938.

“Darülfünun' da Dördüncü Gaz Konferansı.” Cumhuriyet, 10 Mayıs 1933.

"Doktorlar İçin Bir Kurs Açılıyor.” Cumhuriyet, 18 Şubat 1936.

"Edirne'de Gaz Konferansı." Cumhuriyet, 10 Nisan 1938.

“Gaz Maskeleri.” Cumhuriyet, 9 Birinci Kanun [Aral1k] 1938.

“Gazler ve Sisler." Cumhuriyet, 12 Mayıs 1933.

“Gümüşsuyu'ndaki Kurs Bitti." Cumhuriyet, 23 Temmuz 1941.

Güngör, Selahattin. "Gaz Maskesi Satışı Hararetle Devam Ediyor." Cumhuriyet, 20 Birinci Kanun [Aralık] 1938.

"Halk Maskeleri Satışı." Akşsam, 22 Nisan 1939.

"Halk Maskeleri Satışı." Cumhuriyet, 10 Birinci Kanun [Aralık] 1938.

"Hava Hücumlarına Karşı Alınan Korunma Tedbirleri." Cumhuriyet, 14 Ağustos 1939, 3.

"Hava Hücumlarına Karşı Şehirlerde Sığınaklar, Gaz Odaları Yapılacak.” Cumhuriyet, 5 Kânunusani [Ocak] 1934.

"Hava Hücumlarından Korunma Cemiyeti Beyannamesi." Cumhuriyet, 21 Teşrin-i Evvel [Ekim] 1933.

"Hava Koruma Cemiyeti Faaliyete Başliyor." Cumhuriyet, 30 Eylül 1933.

"Hava Tehlikesine Karşı Hazırlıklı Bulunacağız." Cumhuriyet, 26 Temmuz 1935.

“İönü Halkevinde Kurslar.” Cumhuriyet, 22 Şubat 1938.

“Kastamonu'da Zehirli Gaz Kursu.” Cumhuriyet, 10 Ağustos 1936.

“Kırklareli’nde Zehirli Gaz Kursu.” Cumhuriyet, 17 Mart 1939. 
“Manisa Halkevinde Yeni Bir Kurs Açıldı.” Akşam, 21 Nisan 1939.

“Maske Fabrikamız Dün Çalışmaya Başladı.” Cumhuriyet, 1 İkinci Teşrin [Kasım] 1935.

“Maske Fabrikası Yakında Halk İçin Maske İmaline Başlıyor.” Cumhuriyet 27 İkinci Teşrin [Kasım] 1938.

Mustafakemalpaşa Kazasında Açılan Gaz Kursu.” Cumhuriyet, 30 Mayıs 1937.

“Niğde Memurları İçin Zehirli Gaz Kursu Açıldı.” Cumhuriyet, 7 Haziran 1937.

“Ordu’da Zehirli Gaz Kursu.” Cumhuriyet, 24 Temmuz 1936.

"Perşembe Günü Verilecek Konferanslar.” Cumhuriyet, 25 Nisan 1933.

“Sivas’ta Zehirli Gaz Kursu.” Cumhuriyet, 20 İkinci Teşrin [Kasım] 1936.

“Şehirde 45 Gaz Kursu Açılıyor.” Cumhuriyet, 10 İkinci Teşrin [Kasım] 1937.

T.B.M.M. Zabıt Ceridesi, Devre 4, Cilt 9, İçtima 1, s. 341-344.

T.C. Resmi Gazete, say1 1097, 29 Kânun-u Sânî [Ocak] 1929; sayı 2676, 15 Nisan 1934; say1 3036,24 Haziran 1935, say1 3055, 16 Temmuz 1935; sayı 3548, 8 Mart 1937; say1 3638, 23 Haziran 1937; say1 3955, 9 Temmuz 1938; say1 4142, 25 Şubat 1939; say1 4178, 8 Nisan 1939; say1 4186, 18 Nisan 1939; sayı 4188, 20 Nisan 1939; sayı 4418, 27 Kânun-u Sani [Ocak] 1940; sayı 4532, 11 Haziran 1940; say1 5460, 20 Temmuz 1943; say1 28281, 3 May1s 2012.

“Trabzon’da Zehirli Gaz Kursları Açıldı.” Cumhuriyet, 25 Nisan 1937.

“Yakında Korunma Kursları Açılacak.” Cumhuriyet, 9 İkinci Kanun [Ocak] 1936.

"Yüksek Gaz Kursu Açılıyor.” Cumhuriyet, 18 İkinci Teşrin [Kasım] 1937.

“Zehirli Gaz İçin Yapılan Elbise: Bir Türk Sanatkârının İcadı Beğenildi.” Cumhuriyet, 30 Haziran $1934,4$.

“Zehirli Gaz Kursları Faaliyete Geçti.” Cumhuriyet, 5 Birinci Teşrin [Ekim] 1939.

“Zehirli Gaz Kursu: Kursa Devam Etmeyenler Para Cezası Alacak.” Cumhuriyet, 24 Mart 1937.

“Zehirli Gazlar İçin Dün Hükümet ve Belediye Doktorlarına Bir Konferans Verildi.” Cumhuriyet, 19 Şubat 1936.

“Zehirli Gazlardan Korunma Cemiyeti.” Cumhuriyet, 22 Eylül 1933.

“Zehirli Gazler Kursularına Devam Edecek Memurlar.” Cumhuriyet, 8 Mart 1937.

“Zehirli Gazler.” Cumhuriyet, 26 Nisan 1933.

“Zehirli Gazlerden Korunma Çareleri.” Cumhuriyet, 28 Nisan 1933.

“Zehirli Gazlere Karşı Halkı Koruma Yerleri.” Cumhuriyet, 24 Temmuz 1935.

“Zehirli Gazlere Karşı Şimdiden Hazırlanmalı.” Cumhuriyet, 5 Mayıs 1933.

\section{Elektronik Kaynaklar / Electronic Sources}

“Ankara Mamak’ta Kurulan Zehirli Gaz Maskesi Fabrikası’nın Açılış Töreninde Yapılan Konuşma. Erişim 20 Haziran 2019. http://www.ismetinonu.org.tr/ismet-inonu-1933-1938.htm\#_ftn137

“Bilgilendirme.” Erişim 2 Mayıs 2019. https://www.afad.gov.tr/tr/23456/KBRN

“TSK’nın Çok Özel 55 Adamı." Erişim 2 Mayıs 2019. http://www.milliyet.com.tr/gundem/tsknin-cok-ozel55-adami-1870862

TBMM. Albümü 1920-2010 1. Cilt 1920-1950, yayına hazırlayanlar Sema Y1ldırım ve Behçet Kemal Zeynel. Ankara: TBMM Basın ve Halkla İlişkiler Müdürlüğü, 2010. Erişim 5 Nisan 2019. https://www.tbmm. gov.tr/TBMM_Album/Cilt1/index.html 